\author{
ACTA MYCOLOGICA \\ Vol. 46 (1): 27-73 \\ 2011
}

\title{
Rare species of the genus Coprinus Pers. s. lato
}

\author{
BŁAŻEJ GIERCZYK ${ }^{1}$, ANNA KUJAWA², TOMASZ PACHLEWSKI ${ }^{3}$, \\ ANDRZEJ SZCZEPKOWSKI ${ }^{4}$ and MICHAE WÓJTOWSKI ${ }^{1}$ \\ ${ }^{1}$ Faculty of Chemistry, A. Mickiewicz University, Grunwaldzka 6 \\ PL-60-780 Poznań, hanuman@amu.edu.pl,wojton@amu.edu.pl \\ ${ }^{2}$ Field Station in Turew, Institute for Agricultural and Forest Environment \\ Polish Academy of Sciences, Szkolna 4, PL-64-000 Kościan, ankujawa@man.poznan.pl \\ ${ }^{3}$ Lubuska 3/17, PL-53-514 Wrocław, tomasz.pachlewski@gmail.com \\ ${ }^{4}$ Department of Mycology and Forest Phytopathology, Warsaw University of Life Sciences - SGGW \\ Nowoursynowska 159, PL-02-776 Warszawa, andrzej_szczepkowski@sggw.pl
}

Gierczyk B., Kujawa A., Pachlewski T., Szczepkowski A., Wójtowski M.: Rare species of the genus Coprinus Pers. s. lato. Acta Mycol. 46 (1): 27-73, 2011.

The paper presents a list of fifty-five coprinoid fungi found in Poland, which have been not reported earlier from this area (28 species) or are known only from few localities. Four species new to Poland collected in Bieszczady Mts and mentioned, without descriptions, in earlier papers, were also included and described in this publication. For the species new to Poland, illustrations and short descriptions based on the specimens examined and literature data, are given.

Key words: Basidiomycota, Coprinus, Coprinellus, Coprinopsis, Parasola, diversity, distribution, species new to Poland

\section{INTRODUCTION}

Until the end of XX century the species of agaricoid fungi, characterized by the presence of distinct pseudoparaphyses and deliquescent, dissolving as the result of autolysis, lamellae (and whole fruitbodies) were grouped into the genus Coprinus Pers. Further molecular investigations have indicated that from the phyllogenetic point of view it is a heterogeneous taxon. The characters distinguishing this group (so called coprin syndrome) must have originated at least twice during the basidiomycetes evolution. In the current literature coprinoid fungi are divided into four genera: Coprinus Pers., Coprinellus P. Karst., Coprinopsis P. Karst., and Parasola Redhead, Vilgalys \& Hopple (Hopple, Vilgalys 1999; Moncalvo et al. 2002; Vellinga 2004; Redhead et al. 2001; Vesterholt et al. 2007; Vesterholt 2008a-d). First of them 
is placed in the Agaricaceae, the others in the Psathyrellaceae (Kirk et al. 2008). The genus Coprinus Pers. is separated from the others on the basis of absence of radial groving of the outer part of the pileus. Species belonging to the genus Coprinellus $\mathrm{P}$. Karst. have distinct, hyaline pileocystidia and caulocystidia, which are absent in the other groups. The species of Coprinopsis P. Karst. species differ from a belonging to genus Parasola Redhead, Vilgalys \& Hopple by the presence of veil on the cap and stem. Veil is also present on the pilei of the few species from the genus Coprinellus P. Karst.

Because of the basidiocarps fragility and their occurrence in the habitats which are rarely investigated by mycologists (pastures, meadows, studs), coprinoid fungi are poorly recognized in Poland. By now, 54 species of genus the Coprinus s. lato were found within this area, a lot of them are known only from single localities (Wojewoda 2003; Bujakiewicz 2004; Ślusarczyk 2004; Nita, Bujakiewicz 2005; Gierczyk et al. 2009). In the northern of Europe about 120-150 species from this group occur (Orton, Watling 1979; Uljé 2005; Vesterholt 2008a-d; Doveri 2004).

\section{MATERIAL AND METHODS}

We present a list of fifty-five coprinoid fungi found in Poland during mycological investigations in the years 2006-2009, which have not been reported earlier from this area (28 species) or are known only from a few localities. Four species (Coprinopsis acuminata, $C$. aff. argentea, $C$. tigrinella and $C$. urticicola), first time collected in Poland during mycological trips to Bieszczady Mts and mentioned, without descriptions by Gierczyk et al. (2009) are also included and described. For the species new to Poland short descriptions and illustrations, based on the specimens examined and literature data, are given. The species found in Bieszczady Mts mentioned above were fully characterized (micro- and macrocharacters as well as detailed ecological data were given). The collected material was deposited in the herbarium of Field Station of the Institute for Agricultural and Forest Environment, Polish Academy of Sciences (ZBŚRiL), in the author's (BG) private herbarium (BGF) and in Marek Snowarski's private herbarium (MS). Names (except for Coprinellus elisii) are given according to Funga Nordica (Vesterholt 2008a-d), threat categories according to Wojewoda and Ławrynowicz (2006). Information about species distribution are given according to Orton and Watling (1979), Doveri (2004), Legon et al. (2005), Uljé (2005) and Vesterholt (2008a-d). The material was studied according to standard methods used in the taxonomy of fungi. The microscopic structures were examined in dried material, mounted in Congo Red or $10 \%$ ammonia and in fresh material mounted in water, using Bresser Bino Researcher microscope. Drawings of microcharacters were made from microphotographs taken with Nikon Coolpix 950 Digital Camera. All measurements were made directly through the microscope under an oil immersion objective. 


\section{RESULTS}

\section{LIST OF SPECIES}

\section{Coprinellus P. Karst.}

Coprinellus bisporus (J.E. Lange) Vilgays, Hoppe \& Jacq. Johnson (Coprinus bisporus J.E. Lange), E

DesCription AND ICONOGRAPHY: Uljé (2005): 52-53, Fig. 35; Orton, Watling (1979): 88, 144-145, Fig. 205, 210; Ludwig (2007a): 76, Tabl. 262, Fig. 93.33A-C; Ludwig (2007b): 184-185; Doveri (2004): 202-204 (an error on the figure presenting this species occurs - spores are shown to be warty); Moser (2002): III/ Coprinus/23; Breitenbach, Kränzlin (1995): Vol. 4, Fig. 267.

LocAlities: 1. Between Bukowiec and Sworzyce, near Opalenica; ATPOL: BD-14. Two basidiocarps were found on horse dung mixed with straw; 10.05.2009; leg., det. B. Gierczyk; BGF/090510/0001. 2. Bieszczady National Park, horse stud in Wołosate village; ATPOL: FG-79. A few fruitbodies were found on horse dung mixed with straw; 26.06.2009, 06.10.2009, 05.06.2010; leg. T. Pachlewski, B. Gierczyk, det. B. Gierczyk; BGF/090626/0002, BGF/091006/0001, BGF/100605/0005.

Distribution AND REMARKs: Coprophilous species, growing mainly on dung or mixtures of dung and straw, occasionally also on decaying straw, known from Europe and North America, common in many countries. Found on four localities in Poland (Wojewoda 2003; Lisiewska, Galas-Świdurska 2005).

Coprinellus callinus v. callinus (M. Lange \& A.H. Sm.) Redhead, Vilgalys \& Moncalvo (Coprinus callinus v. callinus M. Lange \& A.H. Sm.)

Fig. 1

Description AND ICONOGRaphy: Uljé (2005): 46-47, Fig. 23; Orton, Watling (1979): 93-94, 144-145, Fig. 196; Ludwig (2007a): 74, Tabl. 260, Fig. 93.22A\&B; Ludwig (2007b): 171-172.
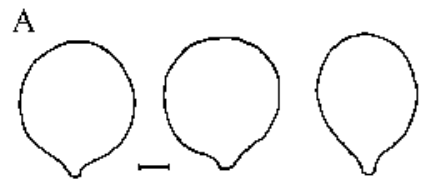

D

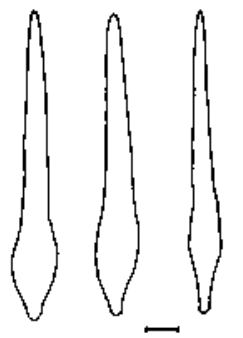

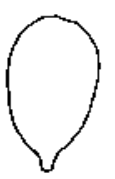
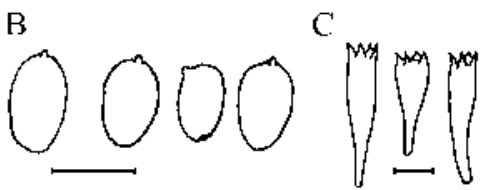

E

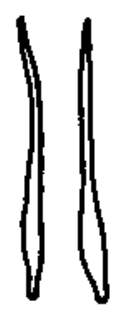

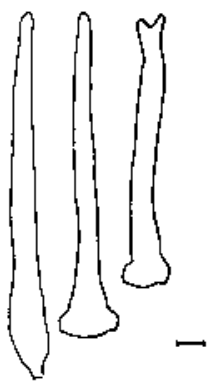

Fig. 1. Coprinellus callinus v. callinus microcharacters: A - cheilocystidia, B - spores, C - basidia, D - pileocystidia, E - caulocystidia. Scale bars $=10 \mu \mathrm{m}$. 
MACROSCOPIC AND MICROSCOPIC FEATURES: Basidiocarps medium-sized, expanded pileus up to $35 \mathrm{~mm}$, first ovoid or ellipsoid, then convex or flat, stipe 50-110 $\times 1-2.5$ mm. Cap cinnamon, ochre, yellow-brown to pale red-brown, stipe greyish-white. Spores 9.0-12.0 × 5.5-7.0 $\mu \mathrm{m}$ (lit. 9.5-13.0 × 5.5-7.5 $\mu \mathrm{m}$ ), ovoid to ellipsoid, dark redbrown, with distinct, eccentric germ pore, base and apex rounded. Basidia 4-spored, $15-40 \times 8-11 \mu \mathrm{m}$ (lit. 14-38 $\times$ 8-10 $\mu \mathrm{m}$ ). Cheilocystidia globose to ellipsoid, 25-50 $\times 25-55 \mu \mathrm{m}$ (lit. 20-60 × 15-50 $\mu \mathrm{m}$ ), pleurocystidia absent. Pileocystidia lageniform with tapering neck, 70-160 × 10-22 $\mu \mathrm{m}$ (lit. 60-200 × 6-25 $\mu \mathrm{m}$ ). Caulocystidia subcylindrical with broadened base. Sclerocystidia and clamps present.

LocalitiEs: Ogrodniczki village near Supraśl; ATPOL: GC-01. One basidiocarp on soil mixed with compost, in garden; 24.09.2009; leg. M. Gryc, det. B. Gierczyk; BGF/BF/090924/0001.

DisTRIBUTION, HABITAT AND REMARKS: Widespread and rather common ink-cap species, known from Europe and North America, occurring subfasciculate terrestrially, often along paths, among wood chips. A species new to Poland.

\section{Coprinellus congregatus (Bull.) P. Karst. (Coprinus congregatus (Bull.) Fr.), E}

DESCRIPTION AND ICONOGRAPHY: Uljé (2005): 49, Fig. 28; Orton, Watling (1979): 88-89, 142-145, Fig. 186, 209, 211; Ludwig (2007a): 75, Tabl. 261, Fig. 93.31A\&B; Ludwig (2007b): 181-182; Moser (2002): III/ Coprinus/21; Doveri (2004): 211-213.

LocAlities: $1.2 \mathrm{~km} \mathrm{~S}$ from Lusówko village near Poznań, in the forest along a red bicycle route on the southern bank of Lusowskie lake; ATPOL: BD-07. A few basidiocarps were found on putrefying, cut grass (maybe mixed with dung); 26.07.2009; leg., det. B. Gierczyk; BGF/090726/0003. 2. Bieszczady National Park, horse stud in Wołosate village; ATPOL: FG-79. Two fruitbodies were found on horse dung mixed with straw; 06.10.2009; leg., det. B. Gierczyk; BGF/091006/0005.

Distribution AND REMARKs: Common and widespread coprophilous species, growing mainly on dung and dung mixed with straw, known from Europe and North America. Hitherto reported in four localities in Poland (Wojewoda 2003; Bujakiewicz 2004; Gierczyk et al. 2009).

Coprinellus curtus (Kalchbr.) Vilgalys, Hoppe \& Jacq. Johnson (Coprinus curtus Kachlbr.)

Description AND iconography: Uljé (2005): 40-41, Fig. 12; Orton, Watling (1979): 85-86, 140-141, Fig. 175; Ludwig (2007a): 78, Tabl. 264, Fig. 93.44; Ludwig (2007b): 195-196; Doveri (2004): 199-202.

Localities: 1. Bieszczady Mts, Bieszczady National Park, spruce coppice near the camping in Wetlina village; ATPOL: FG-68. A few individuals were found on horse dung; 23.06.2009; leg. T. Pachlewski, B. Gierczyk, det. B. Gierczyk; BGF/090701/0002. 2. Bieszczady National Park, Bereżki village, pasture near tourist trail; ATPOL: FG69. Two basidiocarps were found on horse dung; 27.06.2009; leg., det. B. Gierczyk; BGF/090627/0001. BGF/090701/0001.

DisTRIBUTION AND REMARKs: Widespread but rather rare species, known from Europe, North America and Japan, growing on dung of herbivores. Hitherto recorded in two localities in Poland: "Wielki Las" forest and Białowieża National Park (Bujakiewicz 1973; Chmiel, Sadowska 1994). 
Coprinellus elisii (P.D. Orton) Redhead, Vilgalys \& Moncalvo (Coprinus elisii P.D. Orton)

DesCRIPTION AND ICONOGRAPHY: Uljé (2005): 91, Fig. 97; Orton, Watling (1979): 57-58, 130-131, Fig. 99, 107; Ludwig (2007a): 94, Tabl. 280, Fig. 93.105A\&B; Ludwig (2007b): 268-270.

LocAlities: 1. Łany near Wrocław, ATPOL: CE-50. On the sandy and stony meadow near Odra river one basidiocarp grew on a wood-chip; 08.11.2008; leg. B. Gierczyk, T. Pachlewski, det. B. Gierczyk, BGF/081108/0021. 2. Bieszczady National Park, W from Ustrzyki Górne village, near the parking place at the start of the tourist trail to Wielka Rawka Mt., at the bank of the Rzeczyca stream; ATPOL: FG-69. One basidiocarp was found on the Alnus incana trunk in the mixed forest; 27.06.2009; leg., det. B. Gierczyk; BGF/090627/0002.

DisTRIBUTION AND REMARKS: Widespread, but uncommonly mentioned fungus in Europe, growing terrestrial, on dead leaves or twigs of deciduous trees. Because of its morphological and ecological similarity to very common ink-cap species - Coprinellus domesticus (Bolt.) Vilgalys, Hopple \& Jacq. Johnson, it is probably overlooked and doubtfully determined. Some authors (i.e., Vesterholt 2008a) recognize C. elisii as conspecific with $C$. domesticus, while other mycologists (e.g., Ludwig 2007a, b; Uljé 2005) describe it as a "good" species. The main character differentiating these species is the spore width, (3.5)4.0-5.0 $\mu \mathrm{m}$ for $C$. domesticus and 3.0-4.0 $\mu \mathrm{m}$ for C. ellisii, respectively. Additionally, the basidiocarps of the $C$. ellisii are smaller and have the volva-like stipe base. It is not mentioned in Checklist of Polish Large Basidiomycetes, until now known from two localities in Poland (Bujakiewicz 2004, 2006; Nita, Bujakiewicz 2007).

\section{Coprinellus flocculosus (DC.) Vilgays, Hoppe \& Jacq. Johnson (Coprinus flocculosus DC.), $\mathbf{R}$}

DesCRIPTION AND ICONOGRAPHY: Uljé (2005): 88-89, Fig. 35; Orton, Watling (1979): 60, 130-131, Fig. 102, 108, 113; Ludwig (2007a): 82, Tabl. 268, Fig. 93.58A-C; Ludwig (2007b): 213-214; Doveri (2004): 162164; Moser (2002): III/Coprinus/14; Breitenbach, Kränzlin (1995): Vol. 4, Fig. 277.

Localities: 1. Poznań, NW part of "Uroczysko Marcelin" forest, birch forest along Dziewińska street; ATPOL: BD-08. One fruitbody on a branch of deciduous tree was found; 12.06.2009; leg., det. B. Gierczyk; BGF090612/00001. 2. Bieszczady Mts, Bieszczady National Park, grassland near the camping in Wetlina village; ATPOL: FG-68. A few individuals grew on straw mixed with twigs near the forest margin; 29.06.2009; leg., det. B. Gierczyk; BGF/090626/0003. 3. Bieszczady Mts, Bieszczady National Park, horse stud in Wołosate village; ATPOL: FG-79. One basidiocarp was found on the straw mixed with horse dung; 06.06.2010; leg. A. Kujawa, det. B. Gierczyk; BGF/100605/0001.

DisTRIBUTION AND REMARKS: Rare ink-cap but widespread in Europe, known from many European countries, growing on wood-chips but also on decaying straw and straw-dung mixture. Found in four localities in Poland (Wojewoda 2003).

Coprinellus heptemerus (M. Lange \& A. H. Sm.) Vilgalys, Hopple \& Jacq. Johnson (Coprinus heptemerus M. Lange \& A. H. Sm.)

DesCription AND ICONOGRAPHY: Uljé (2005): 41, Fig. 13; Orton, Watling (1979): 86-87, 140-141, Fig. 171, 174, 176, 177; Ludwig (2007a): 78, Tabl. 264, Fig. 93.45A\&B, 93.46A\&B; Ludwig (2007b): 196-199; Doveri (2004): 194-197; Breitenbach, Kränzlin (1995): Vol. 4, Fig. 280. 
Localities: Kaczawskie Mts, “Góra Miłek” reserve near Wojcieszów village, ATPOL: BE-61. A dozen of basidiocarps on horse dung in beech forest belonging to Cephalanthero-Fagenion alliance was found; 03.10.2008; leg., det. B. Gierczyk; BGF081003/0012.

DisTRIBUTION AND REMARKs: The fungus widespread in Europe and North America, also found in Japan, growing on dung of various animals. Known from Great Britain, Scandinavian Countries, Netherlands and Italy. In Poland until now mentioned only from two localities: "Pniowski Ług" reserve (Ślusarczyk 2004) and Bieszczady Mountains (Gierczyk et al. 2009). The specimens from "Góra Miłek" reserve differ in the spore size from the descriptions given by Uljé (2005) or Orton and Watling (1979). In the specimens examined, spore length does not exceed $13 \mu \mathrm{m}$ (average dimensions: $10-12 \times 6-8 \mu \mathrm{m})$. The spore size $12.5-16.5 \times 7-8.5 \mu \mathrm{m}$ is given by cited authors. According to Doveri (2004), collections with smaller spores are sometimes described as a typus forma - C. heptemerus f. parvisporus J. Breitenb. \& F. Kränzl., and are known from Great Britain, Italy and Spain. From Czech Republic a species similar to $C$. heptemerus, but characterized by spores up to $11.5 \mu \mathrm{m}$ long, was described as C. pusillulus Svrček (Svrček 1983), but it is probably an infraspecific variant of the discussed taxon (Vesterholt 2008a). It was included by Ludwig (2007a, b) into $C$. heptemerus as a variety: C. heptemerus v. pusillulus (Svrček) E. Ludw. and recognized as a synonym of $C$. heptemerus f. parvisporus.

Coprinellus heterosetulosus (Watling) Vilgalys, Hopple \& Jacq. Johnson (Coprinus heterosetulosus Watling)

Fig. 2

DESCRIPTION AND ICONOGRAPHY: Uljé (2005): 51, Fig. 32; Orton, Watling (1979): 91-92, 144-145, Fig. 212, 214-216; Ludwig (2007a): 76, Tabl. 262, Fig. 93.35A\&B; Ludwig (2007b): 186-187; Doveri (2004): 207-211; Breitenbach, Kränzlin (1995): Vol. 4, Fig. 281.

MacroscopiC AND MICROSCOPIC FEATUREs: Basidiocarps small, cap up to $10 \mathrm{~mm}$, first oblong to ellipsoid, then obtusely conical to flat, stipe $15-50 \times 0.25-0.75 \mathrm{~mm}$. Pileus date-brown to umbra-brown with paler margin. Spores ellipsoid to ovoid, 8.0$11.0 \times 4.8-6.0 \mu \mathrm{m}$ (lit. 8.0-11.0 × 5.0-6.5 $\mu \mathrm{m}$ ) with rounded base and apex and eccentric germ pore, dark red-brown. Basidia 4-spored, 20-35 × 8-11 $\mu \mathrm{m}$ (lit. 16-32 $\times$ 8.5-10 $\mu \mathrm{m}$ ). Cheilocystidia subglobose to ovoid, 15-25 $\times 15-20 \mu \mathrm{m}$ (lit. 13-25 $\times 12-18$ $\mu \mathrm{m})$, facial cystidia absent. Pileocystidia lageniform with tapering neck, 25-105 $\times 10-$ $18 \mu \mathrm{m}$ (lit. 30-95 × 8-21 $\mu \mathrm{m}$ ). Sclerocystidia present, similar to pileocystidia.

Localities: 1. Bieszczady Mts, Bieszczady National Park, spruce coppice near the camping in Wetlina village; ATPOL: FG-68. A few individuals grew on horse dung; 23.06.2009, 06.10.2009, 05.06.2010; leg. T. Pachlewski, B. Gierczyk, det. B. Gierczyk; BGF/090701/0003, BGF/091006/0002, BGF/100605/0011. 2. Białowieża Primeval Forest, Białowieża National Park, compartment no. 345B; ATPOL: GC-56. A few basidiocarps were found on deer dung; leg. A. Szczepkowski, det. B. Gierczyk; BGF/091018/0002, BGF/091024/0011 (obtained in laboratory culture).

Distribution, HABITAT AND REMARKs: Coprophilous ink-cap, known from Europe and North America, rather common, occurring solitary on weathered dung of herbivores, mainly horses. Rarely collected and overlooked probably because of its small dimensions. A species new to Poland. 

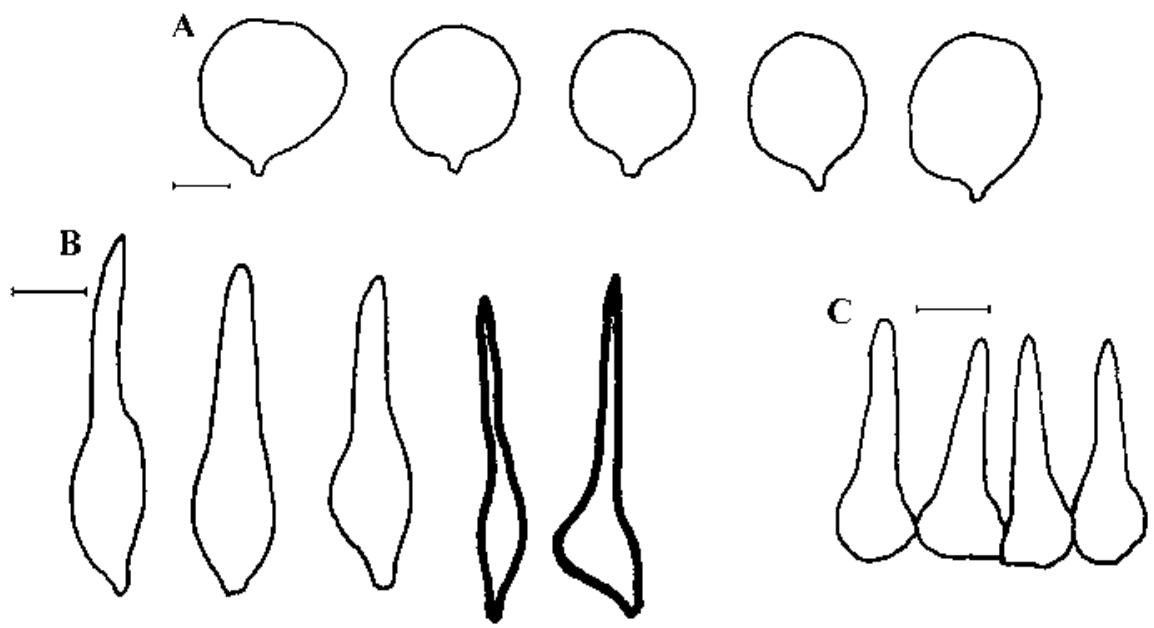

D
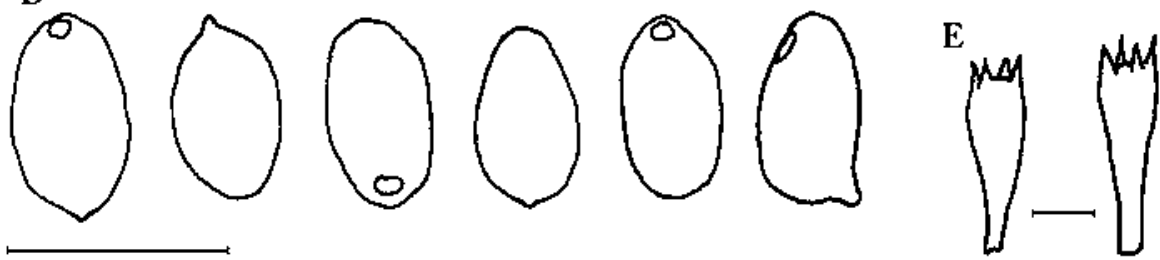

Fig. 2. Coprinellus heterosetulosus microcharacters: A - cheilocystidia, B - pileocystidia, $\mathrm{C}$ - caulocystidia, D - spores, E - basidia. Scale bars $=10 \mu \mathrm{m}$.

Coprinellus marculentus (Britzelm.) Redhead, Vilgalys \& Moncalvo (Coprinus marculentus Britzelm.)

Fig. 3, Phot. 1

DESCRIPTION AND ICONOGRAPHY: Uljé (2005): 40, Fig. 11; Orton, Watling (1979): 83-84, 140-141, Fig. 170, 173, 180 (as C. hexagonosporus); Ludwig (2007a): 78, Tabl. 264, Fig. 93.43; Ludwig (2007b): 194-195; Doveri (2004): 197-199; Breitenbach, Kränzlin (1995): Vol. 4, Fig. 292.

MACROSCOPIC AND MICROSCOPIC FEATURES: Basidiocarps medium-sized, expanded pileus up to $25 \mathrm{~mm}$, first subglobose, ovoid to ellipsoid, then flat, stipe $40-80 \times 1-2$ $\mathrm{mm}$. Cap yellow-brown with dark red-brown centre, covered with globose velar cells,

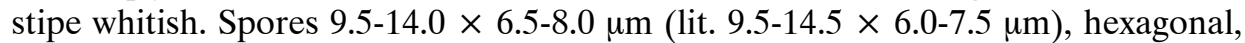
dark red-brown, with distinct, eccentric germ pore, base rounded, apex conical. Basidia 4-spored, 20-35 × 10-13 $\mu \mathrm{m}$ (lit. 16-38 $\times$ 9-12 $\mu \mathrm{m}$ ). Cheilocystidia globose or ellipsoid, 25-65 × 20-45 $\mu \mathrm{m}$ (lit. 20-70 $\times 17-40 \mu \mathrm{m}$ ), pleurocystidia ellipsoid, subglobose to ovoid. Pileocystidia lageniform, with cylindrical neck and equal to slightly broadened apex, 60-110 × 15-22 $\mu \mathrm{m}$ (lit. 50-100 × 12-20 $\mu \mathrm{m}$ ). Caulocystidia similar to pileocystidia. Sclerocystidia absent, clamps present.

Localities: Bieszczady National Park, horse stud in Wołosate village; ATPOL: FG-79. A dozen of fruitbodies were found on horse dung mixed with straw; 01.05.2010, 05.06.2010; leg. B. Gierczyk, A. Kujawa, det. B. Gierczyk; BGF/100601/0004, $\mathrm{BGF} / 100605 / 0002$. 

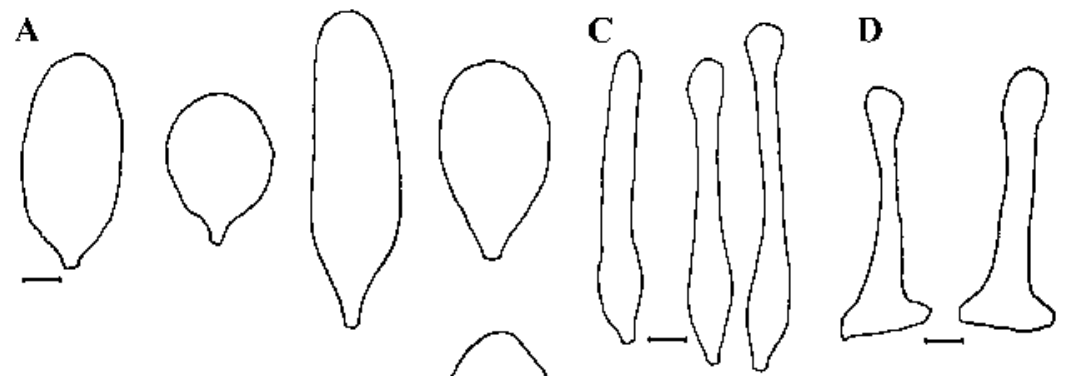

E
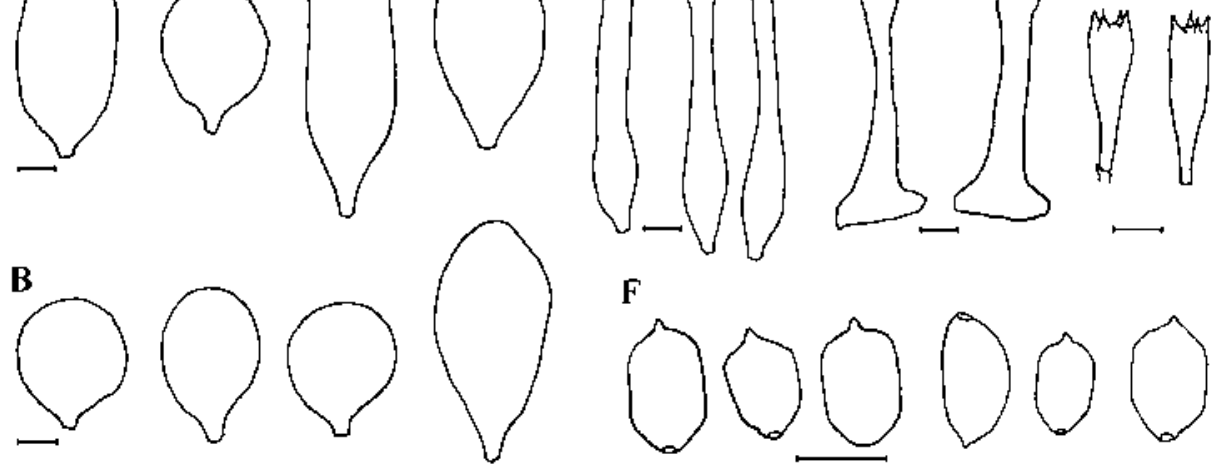

Fig. 3. Coprinellus marculentus microcharacters: A - pleurocystidia, B - cheilocystidia, $\mathrm{C}$ - pileocystidia, D - caulocystidia, E - basidia, F - spores. Scale bars $=10 \mu \mathrm{m}$.

DisTRIBUTION, HABITAT AND REMARKs: Rare but widespread ink-cap species, known from many European countries, North America and Japan, occurring subfasciculate on mixtures of dung and straw, and decaying grasses. A species new to Poland.

Coprinellus pellucidus (P. Karst.) Redhead, Vilgalys \& Moncalvo (Coprinus pellucidus P. Karst.)

Fig. 4

Description And ICONOGRAPHY: Uljé (2005): 50-51, Fig. 31; Orton, Watling (1979): 89-90, 142-145, Fig. 187, 198; Ludwig (2007a): 75, Tabl. 261, Fig. 93.30; Ludwig (2007b): 180-181; Doveri (2004): 207.

MACROSCOPIC AND MICROSCOPIC FEATURES: Basidiocarps small, expanded pileus up to $7 \mathrm{~mm}$, first subglobose, ovoid to ellipsoid, then flat, stipe $15-70 \times 0.1-0.5 \mathrm{~mm}$. Cap white to ochre- or grey-brown, stipe whitish. Spores 8.0-9.5 × 3.5-4.0 um (lit. 6.5-9.5 $\times$ 3.0-4.0 $\mu \mathrm{m}$ ), oblong, cylindrical, dark red-brown, somewhat ovoid, with distinct, central germ pore, base rounded, apex somewhat truncate. Basidia 4-spored, 15-22 $\times$ 6-9 $\mu \mathrm{m}$ (lit. 10-26 × 5-7 $\mu \mathrm{m}$ ). Cheilocystidia globose, 25-35 × 18-20 $\mu \mathrm{m}$ (lit. 20-30 $\times 15-23 \mu \mathrm{m})$, pleurocystidia absent. Pileocystidia lageniform, with tapering neck and somewhat acute apex, 30-45 $\times$ 9-14 $\mu \mathrm{m}$ (lit. 25-50 × 7-12 $\mu \mathrm{m}$ ). Caulocystidia similar to pileocystidia, sometimes subcylindrical. Sclerocystidia and clamps absent.

Localities: 1. Puszcza Notecka forest, Obrzycko village, $0.8 \mathrm{~km}$ W from the Obrzycko-Zamek hamlet; ATPOL: BC-66. A few basidiocarps were found on the weathered horse dung along the path in the mixed forest; 11.11.2009; leg., det. B. Gierczyk; BGF/091111/0001. 2. Bieszczady Mts, Bieszczady National Park, upper part of Górna Solinka Valley, beech forest along a stream; ATPOL: FG-68. A few basidiocarps were found on deer dung in two localities; 06.10.2009; leg., det. B. Gierczyk; BGF/091006/0007, BGF/091006/0007a, BGF/091024/0012 (obtained in laboratory culture).

DisTRIBUTION, HABITAT AND REMARKS: Rather common and widespread ink-cap species, known from many European countries, North America and Japan, occurring solitary on weathered dung of cow, cattle, sheep and other herbivorous animals. Probably overlooked because of small basidiocarp dimensions. A species new to Poland. 

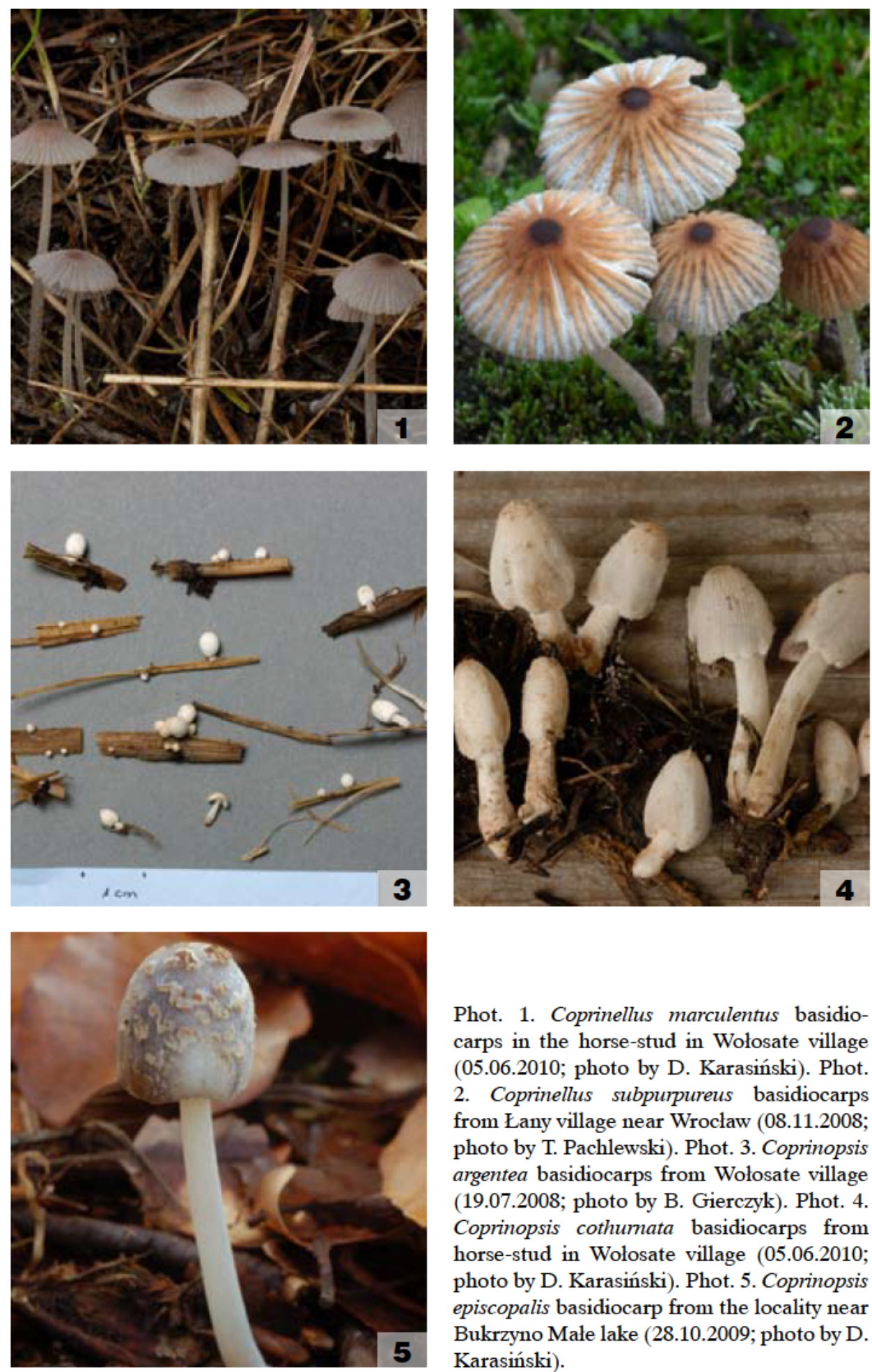

Phot. 1. Coprinellus marculentus basidiocarps in the horse-stud in Wolosate village (05.06.2010; photo by D. Karasiński). Phot. 2. Coprinellus subpurpureus basidiocarps from Łany village near Wrocław (08.11.2008; photo by T. Pachlewski). Phot. 3. Coprinopsis argentea basidiocarps from Wolosate village (19.07.2008; photo by B. Gierczyk). Phot. 4. Coprinopsis cothurnata basidiocarps from horse-stud in Wolosate village (05.06.2010; photo by D. Karasiński). Phot. 5. Coprinopsis episcopalis basidiocarp from the locality near Bukrzyno Male lake (28.10.2009; photo by D. Karasinski). 

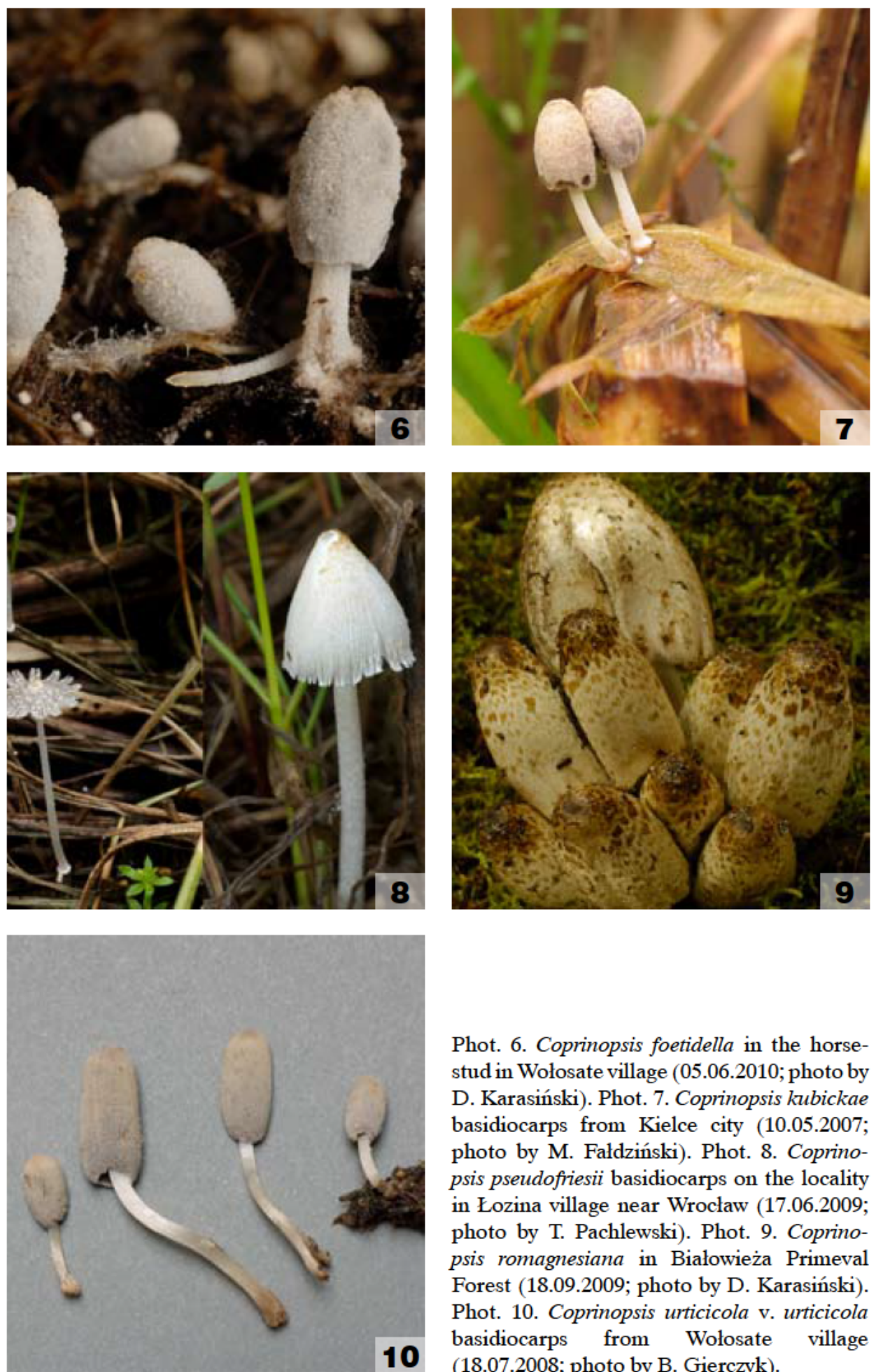

Phot. 6. Coprinopsis foetidella in the horsestud in Wolosate village (05.06.2010; photo by D. Karasiński). Phot. 7. Coprinopsis kubickae basidiocarps from Kielce city (10.05.2007; photo by M. Faldziński). Phot. 8. Coprinopsis pseudofiresii basidiocarps on the locality in Łozina village near Wroclaw (17.06.2009; photo by T. Pachlewski). Phot. 9. Coprinopsis romagnesiana in Białowieża Primeval Forest (18.09.2009; photo by D. Karasiński). Phot. 10. Coprinopsis urticicola v. urticicola basidiocarps from Wolosate village (18.07.2008; photo by B. Gierczyk). 
A
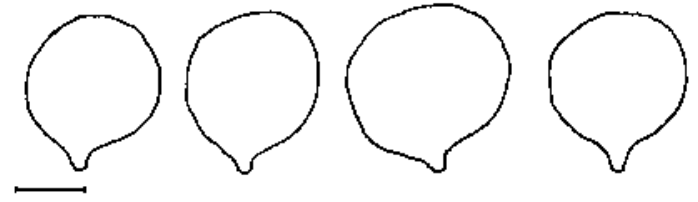

D
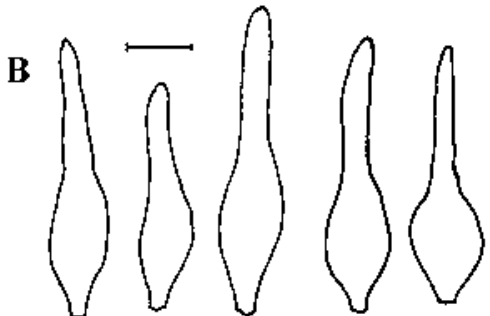

C

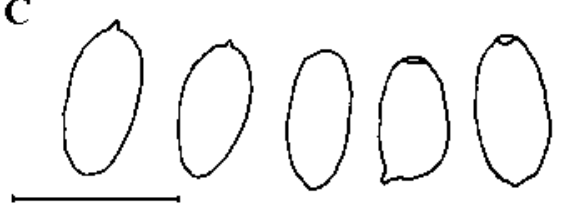

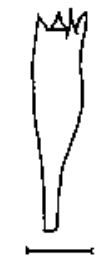
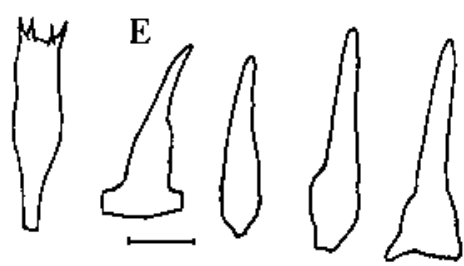

Fig. 4. Coprinellus pellucidus microcharacters: A - cheilocystidia, B - pileocystidia, C - spores, $\mathrm{D}$ - basidia, E - caulocystidia. Scale bars $=10 \mu \mathrm{m}$.

Coprinellus plagioporus (Romagn.) Redhead, Vilgalys \& Moncalvo (Coprinus plagioporus Romagn.)

Fig. 5

DesCription AND iconography: Uljé (2005): 47-48, Fig. 25; Orton, Watling (1979): 95-96, 144-145, Fig. 206; Ludwig (2007a): 75, Tabl. 261, Fig. 93.26A\&B; Ludwig (2007b): 175-177; Moser (2002): III/ Coprinus/22.

MACROSCOPIC AND MICROSCOPIC FEATURES: Basidiocarps medium-sized, pileus up to $30 \mathrm{~mm}$, elliptical to ovoid, finally flat, stipe up to $40-80 \times 1-3 \mathrm{~mm}$. Cap red-brown, very dark when young at centre, paler towards margin, stipe white to grey, pubescent. Spores 10.0-12.0 × 6.0-7.0 $\mu \mathrm{m}$ (lit. 10.5-14.0 $\times$ 6.0-7.5 $\mu \mathrm{m}$ ), ellipsoid to ovoid, dark red-brown, germ pore eccentric. Cheilocystidia globose, up to $35 \mu \mathrm{m}$ wide (lit. 40 $\mu \mathrm{m})$. Pleurocystidia absent. Basidia 4-spored, 28-30 × 8-10 $\mu \mathrm{m}$ (lit. 18-38 × 8-9 $\mu \mathrm{m})$. Pileocystidia lageniform, 70-120 × 10-17 $\mu \mathrm{m}$ (lit. 60-150 $\times 10-18 \mu \mathrm{m})$, with cylindrical neck and blunt to subcapitate apex 7-10 $\mu \mathrm{m}$ width (lit. 7-12 $\mu \mathrm{m}$ ). Sclerocystidia

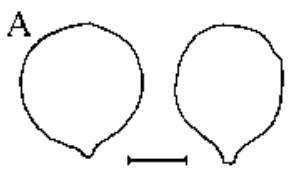

D

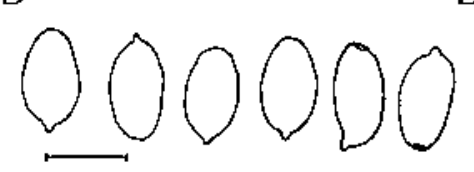<smiles>C1CCCCCCCCC1</smiles>

$\mathrm{E}$<smiles>C1CCCCCC1</smiles>

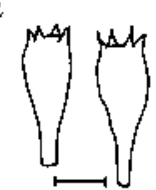

$\mathrm{B}$

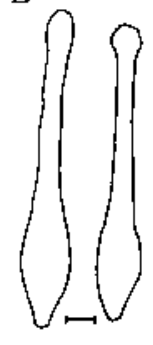

$\mathrm{C}$

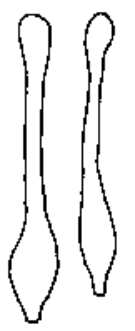

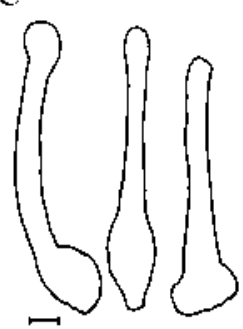

Fig. 5. Coprinellus plagioporus microcharacters: A - cheilocystidia, B - pileocystidia, C-caulocystidia, D - spores, E - basidia. Scale bars $=10 \mu \mathrm{m}$. 
and veil absent. Caulocystidia similar to pileocystidia, $18-40 \times 6.0-9.0 \mu \mathrm{m}$ (lit. 20-50 $\times$ 6.0-10 $\mu \mathrm{m})$. Clamp-connections present.

Localities: $1.3 \mathrm{~km}$ NW from Czerniejewo village, Czerniejewo Forest District, compartment no. 113; ATPOL: CC-92. About 10 basidiocarps on the ground, in Fraxino-Alnetum; 27.09.2009; leg. B. Kudławiec, det. B. Gierczyk; BGF/BF/090927/0001. 2. Bieszczady National Park, Bereżki village, grasslands along tourist trail; ATPOL: FG-69. Two basidiocarps were found on dead grasses; 27.06.2009; leg. A. Kujawa, det. B. Gierczyk; BGF/090627/0003.

DisTRIBUTION, HABITAT AND REMARKS: Rather common and widespread species, known from many European countries and North America, growing terrestrial on clayey soil, among wood-chips, also on twigs, sawdust, compost or leaves. Not mentioned from Poland until present.

Coprinellus radians (Desm.) Vilgalys, Hopple \& Johnson (Coprinus radians (Desm.) Fr.) Description AND iCONOGRAPHY: Uljé (2005): 89-90, Fig. 93\&94; Orton, Watling (1979): 59, 130-131, Fig. 105, 114; Ludwig (2007a): 93, Tabl. 279, Fig. 93.104; Ludwig (2007b): 267-268.

Localities: Złoty Potok village near Częstochowa; ATPOL: DE-96. A few basidiocarps grew on the calcareous ground (probably on strongly decayed, buried branches or other wood), in beech forest; 31.10.2009; leg. K. Kołodziejczyk, det. B. Gierczyk; BGF/BF/091031/0001, BGF/BF/091031/0003.

DisTRIBUTION, HABITAT AND REMARKS: Widespread but not common European species, growing on branches, trunks and logs of deciduous trees. Hitherto known from seven localities in Poland (Wojewoda 2003; Adamczyk 2003a, 2003b).

Coprinellus saccharinus (Romagn.) P. Roux, Guy Garcia \& Dumas (Coprinus saccharinus Romagn.)

DESCRIPTION AND ICONOGRAPHY: Uljé (2005): 86, Fig. 88; Ludwig (2007a): 86, Tabl. 272, Fig. 93.74A\&B; Ludwig (2007b): 231-232.

LocAlities: Poznań, Jeleniogórska street; ATPOL: BD-08. A fascicle consisting of a dozen of basidiocarps was found on the grassy shoulder, just near the dead Acer platanoides trunk; 31.05.2009; leg., det. B. Gierczyk; BGF090531/0001.

DisTRIBUTION AND REMARKs: Rare species but widespread in Europe, known from Germany, Spain, Norway and France, growing on wood and around trunks. In Poland found only once, in Uniejów village near Konin (Lisiewska, Rybak 1990). Its similarity to Coprinellus micaceus (Bull.) Vilgalys, Hopple \& Jacq. Johnson causes that it is probably overlooked. Coprinellus saccharinus differs from the C. micaceus in the absence of caulocystidia and the spores shape, which are ellipsoid, ovoid or only slightly submitriform.

Coprinellus sclerocystidiosus (M. Lange \& A.H. Sm.) Vilgalys, Hopple \& Johnson (Coprinus sclerocystidiocus M. Lange \& A.H. Sm.)

Fig. 6

Description AND ICONOGRAPHY: Uljé (2005): 46, Fig. 22.

MACROSCOPIC AND MICROSCOPIC FEATURES: Basidiocarps medium-sized, pileus up to $35 \mathrm{~mm}$, elliptical to ovoid, finally flat, stipe up to $80 \times 1-2 \mathrm{~mm}$. Cap yellow-brown, rather pale, then greyish-brown, stipe white to greyish, pubescent. Spores 10.0-14.5 
A

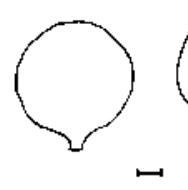<smiles>C1CCCCCC1</smiles><smiles>C1CCCCCCC1</smiles>

$\mathrm{D}$

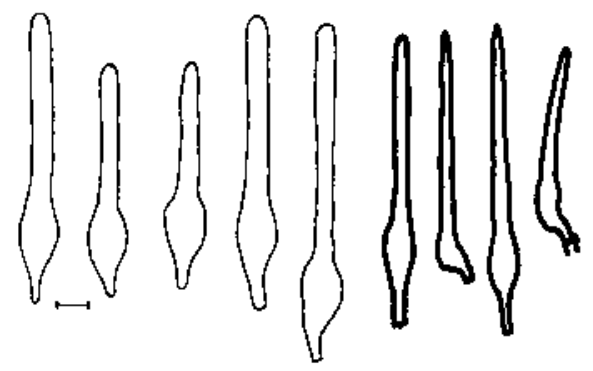

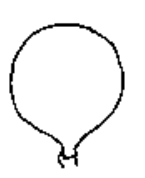

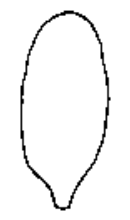

B

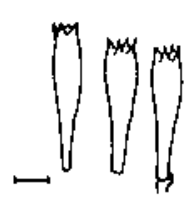

C

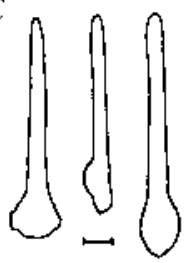

$\mathrm{E}$

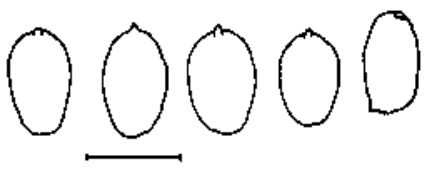

Fig. 6. Coprinellus sclerocystidiosus microcharacters: A - cheilocystidia, B - basidia, C - caulocystidia, D - pileocystidia, E - spores. Scale bars $=10 \mu \mathrm{m}$.

$\times$ 6.5-8.5 $\mu \mathrm{m}$ (lit. 10.5-14.0 × 6.5-8.5 $\mu \mathrm{m}$ ), ellipsoid to ovoid, dark red-brown, germ pore eccentric, apex and base rounded. Cheilocystidia globose, rarely ellipsoid or ovoid up to $60 \times 40 \mu \mathrm{m}$ wide (lit. 20-60 $\times 20-50 \mu \mathrm{m}$ ). Pleurocystidia absent. Basidia 4-spored, 20-25 × 8-10 $\mu \mathrm{m}$ (lit. 18-38 × 8-10 $\mu \mathrm{m}$ ). Pileocystidia lageniform, 50-100 $\times$ 10-15 $\mu \mathrm{m}$ (lit. 40-120 $\times 8-16 \mu \mathrm{m})$, with cylindrical, somewhat tapering neck about 5 $\mu \mathrm{m}$ wide at the apex (lit. 3-8 $\mu \mathrm{m}$ ). Sclerocystidia abundant, especially near cap margin, similar to pileocystidia but with distinctly tapering neck and acute apex. Veil absent. Caulocystidia similar to pileocystidia, 20-50 × 7.0-10.0 $\mu \mathrm{m}$. Clamp-connections present.

LocAlities: Puszcza Zielonka Landscape Park, Zielonka village, near Zielonka Lake; ATPOL: CC-80. A dozen of basidiocarps were found on wood-chips, at the road-side, under Padus serotina and Sambucus nigra shrubs; 20.07.2010; leg., det. B. Gierczyk; BGF/100720/0001.

Distribution, HABITAT AND REMARKs: Rare but widespread species, known from Europe and North America, growing terrestrial in lawns and on wood-chips. Not mentioned from Poland until present.

Coprinellus subimpatiens (M. Lange \& A.H. Sm.) Redhead, Vilgalys \& Moncalvo (Coprinus subimpatiens M. Lange \& A.H. Sm.)

DesCription AND ICONOGRAPHY: Uljé (2005): 45, Fig. 21; Ludwig (2007a): 74, Tabl. 260, Fig. 93.23; Ludwig (2007b): 172-173.

LocAlities: $1.2 \mathrm{~km}$ S from Lusówko village near Poznań, the forest along a red bicycle route; ATPOL: BD-07. One basidiocarp was found on the ground, in the grassy place on the forest path in mixed forest (Corylus avellana, Pinus sylvestris, Tilia sp., Populus tremula); 06.09.2009; leg., det. B. Gierczyk; BGF/090906/0003. 2. Żdżary 
village; ATPOL: CE-37. One basidiocarp was found in the garden, on the ground, among grasses, under Pyrus sp.; 14.05.2010; leg. P. Zawada, det. B. Gierczyk; BGF/ $\mathrm{BF} / 100514 / 0001$.

DistRIBUTION AND REMARKS: Widespread and not rare European ink-cap species, growing on clayey soil. Hitherto two localities of this species are known from Poland: Kazuń near Warszawa and Białowieża National Park (Sadowska 1973; Faliński et al. 1997).

Coprinellus subpurpureus (A.H. Sm.) Redhead, Vilgalys \& Moncalvo (Coprinus subpurpureus A.H. Sm.)

Fig. 7, Phot. 2

Description And iconography: Uljé (2005): 48, Fig. 26; Ludwig (2007a): 74, Tab. 260, Fig. 93.25; Ludwig (2007b): 174-175.

MACROSCOPIC AND MICROSCOPIC FEATURES: Basidiocarps medium-sized, pileus up to $35 \mathrm{~mm}$, first ellipsoid or ovoid, then conical to flat, with dark red-brown centre and paler margins, stipe $40-100 \times 1-3 \mathrm{~mm}$, dull lilac when young, becoming paler with age. Spores 9.5-11.0 × 6.0-6.5 $\mu \mathrm{m}$ (lit. 9.0-11.5 × 5.5-7.0 $\mu \mathrm{m}$ ), ellipsoid to ovoid, dark red-brown, with slightly eccentric germ pore, spores base and apex rounded. Basidia 4-spored, 20-35 $\times 8-9 \mu \mathrm{m}$ (lit. 16-40 $\times$ 8-10 $\mu \mathrm{m}$ ). Cheilocystidia subglobose to broadly utriform, 40-75 $\times 25-30 \mu \mathrm{m}$ (lit. 40-85 $\times 25-45 \mu \mathrm{m}$ ), pleurocystidia absent. Pileocystidia lageniform, 50-80 × 8-15 $\mu \mathrm{m}$ (lit. 45-100 $\times$ 7-14 $\mu \mathrm{m}$ ) with cylindrical neck and even to clavate apex, 5-8 $\mu \mathrm{m}$ wide. Caulocystidia $22-45 \times 7-11 \mu \mathrm{m}$ (lit. $20-40 \times 7-10 \mu \mathrm{m})$, lageniform. Sclerocystidia and veil absent. Clamp-connections present.

LOCALITIES: Łany near Wrocław; ATPOL: CE-50. A dozen of basidiocarps, growing on strongly rotten deciduous wood and leaves, on the sandy and stony meadow
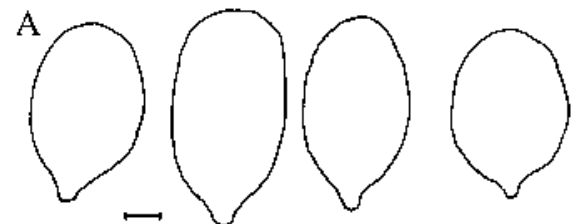

$\mathrm{B}$

$\mathrm{C}$

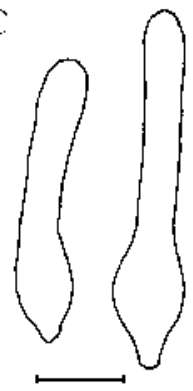

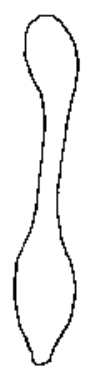

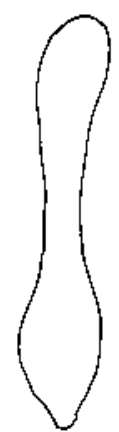

$\mathrm{D}$

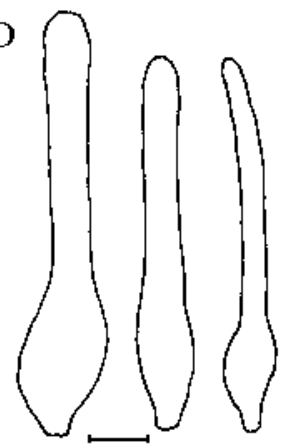

E
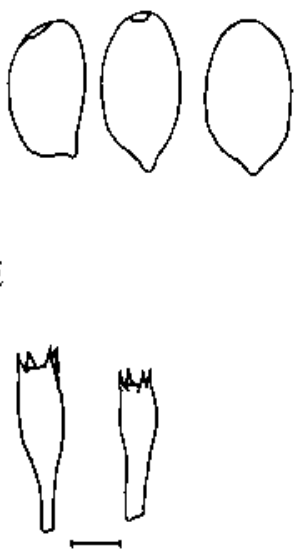

Fig. 7. Coprinellus subpurpureus microcharacters: A - cheilocystidia, B - spores, C - pileocystidia, D - caulocystidia, E - basidia. Scale bars $=10 \mu \mathrm{m}$. 
near Odra river, was found; 08.11.2008; leg. B. Gierczyk, T. Pachlewski, det. B. Gierczyk; BGF/081108/0012.

DisTRIBUTION, HABITAT AND REMARKS: This is a very rare fungus, described from North America, in Europe known only from Germany, Great Britain, Denmark, Norway and Finland. It occurrs solitary or in groups, on moist leaves and black muck. The species is new to Poland.

\section{Coprinopsis P. Karst.}

Coprinopsis acuminata (Romagn.) Redhead, Vilgalys \& Moncalvo (Coprinus acuminatus (Romagn.) P.D. Orton)

Fig. 8

Description And iconography: Uljé (2005): 57-58, Fig. 44; Orton, Watling (1979): 32, 122-123, Fig. 39, 42; Ludwig (2007a): 68, Tabl. 254, Fig. 93.2A\&B; Ludwig (2007b): 148-149; Breitenbach, Kränzlin (1995): Vol. 4, Fig. 266.

MACROSCOPIC AND MICROSCOPIC FEATURES: Basidiocarps medium-sized, pileus up to $50 \mathrm{~mm}$, conical, first greyish to ochre, then grey-brown, with fibrillose, quickly disappearing squamules at centre. Stipe $60-130 \times 3-5 \mathrm{~mm}$, white, with clavate base. Spores 6.5-10.0 × 4.0-5.0 $\mu \mathrm{m}$ (lit. 6.0-10.5 × 4.0-5.5 $\mu \mathrm{m}$ ), ellipsoid to ovoid, with central germ pore and rounded base and apex, dark red-brown. Basidia 4-spored, 16-27 $\times$ 6-9 $\mu \mathrm{m}$ (lit. 14-26 × 6-8 $\mu \mathrm{m}$ ). Cheilocystidia narrowly cylindrical to utriform, 65$110 \times 20-30 \mu \mathrm{m}$ (lit. $60-100 \times 18-28 \mu \mathrm{m})$, pleurocystidia of the same shape, $90-150$ $\times$ 20-30 $\mu \mathrm{m}$ (lit. 80-140 × 18-28 $\mu \mathrm{m}$ ). Veil not seen. Clamps present.

Localities: 1. Puszcza Wkrzańska, Świdwie reserve; ATPOL: AB-62. A few basidiocarps were found on the ground in alder forest; 29.11.2009; leg. K. Olszanowski, det. A. Kujawa, B. Gierczyk; BGF/BF/091129/0001. 2. Rogów village near Łódź, Forest Experimental Station of the Warsaw University of Life Sciences, Rogów Forest District, Forest Range Jasień, compartment no. 75, on the bank of Mroga river;
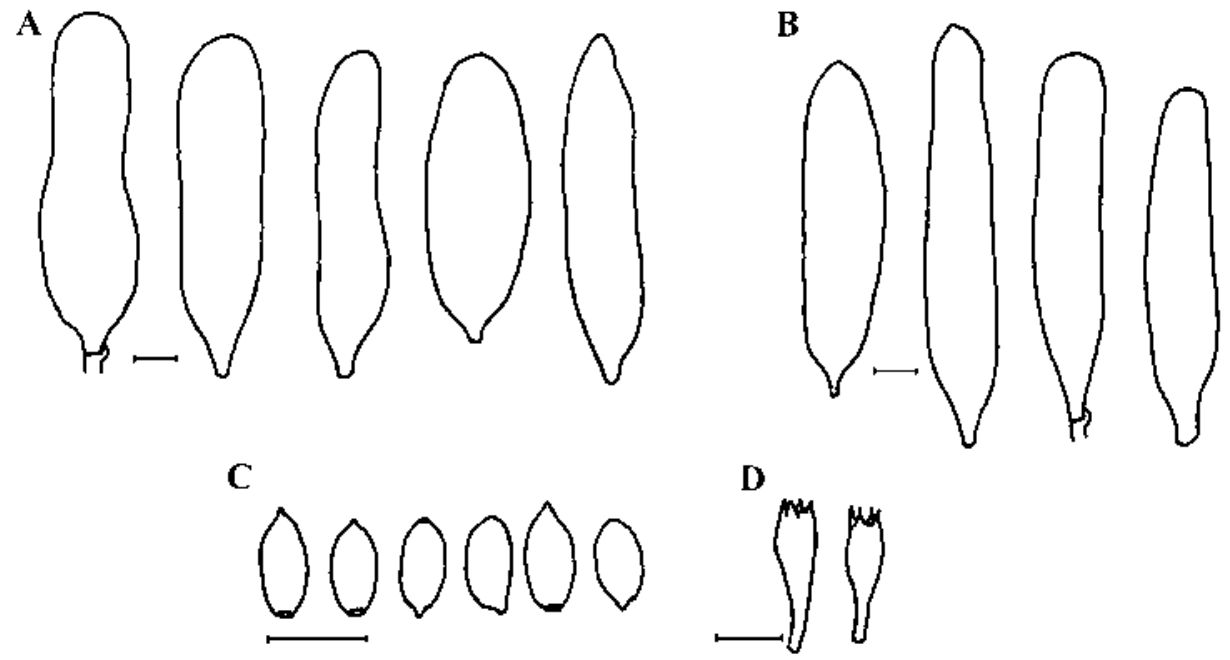

Fig. 8. Coprinopsis acuminata microcharacters: A - cheilocystidia, B - pleurocystidia, $\mathrm{C}$ - spores, D - basidia. Scale bars $=10 \mu \mathrm{m}$. 
ATPOL: DD-78. In Tilio-Carpinetum, on the forest margin, two basidiocarps were found on a piece of wood of an unidentified deciduous tree; 18.09.2006; leg. A. Kujawa, A. Szczepkowski, det. A. Kujawa; MS-060919.10 (photograph in the web atlas of fungi: "Fungi and Mushrooms of Poland" - http://www.grzyby.pl/gatunki/ Coprinus_acuminatus.htm). 3. Bieszczady Mts, Bieszczady National Park, 2 km SEE from Wołosate village, at the slope "Doszczanki" near the red tourist trail; ATPOL: GG-70. One basidiocarp was found in beech forest, on the ground; 10.07.2008; leg. B. Gierczyk; det. A. Kujawa, B. Gierczyk; ZBŚRiL 41/BdPN/100708 (locality mentioned by Gierczyk et al. 2009).

Distribution, HABITAT AND REMARKS: The fungus of a poorly known distribution, probably widespread in Europe, but not distinguished from similar and very common species - C. atramentaria (Bull.) Redhead, Vilgalys \& Moncalvo. The major characters to separate C. acuminata from this species are narrower spores and smaller basidiocarps of ochre-brown color. It occurs in England, Netherlands and Scandinavian Countries, growing fasciculate, on stumps of deciduous trees, fragments of wood or soil. In Poland the species was previously found only in Bieszczady Mts (Gierczyk et al. 2009) and Wigry National Park (Halama, Romański 2010).

Coprinopsis aff. argentea (P.D. Orton) Redhead, Vilgalys \& Moncalvo (Coprinus aff. argenteus P.D. Orton)

Fig. 9, Phot. 3

DESCRIPTION AND ICONOGRAPHY: Orton, Watling (1979): 46, 128-129, Fig. 76-77.

MACROSCOPIC AND MICROSCOPIC FEATURES: Basidiocarps small, pileus up to $15 \mathrm{~mm}$, first elongate, conico-cylindrical, then umbonate, white to grey, becomes ochraceous with age. Veil floccose-hairy, white to pale cream. Stipe 5-25 $\times 1-2 \mathrm{~mm}$, white. Spores 4.5-6.2 × 4.0-5.5 $\mu \mathrm{m}$ (lit. 4.5-6.5 × 4.5-6.0 $\mu \mathrm{m}$ ), ellipsoid, lentiform to kernel of maize shaped, with central germ pore, dark brown. Basidia 4-spored, 10-18 $\times$

A
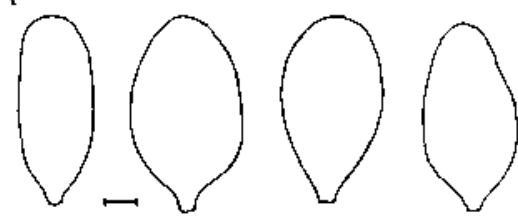

D

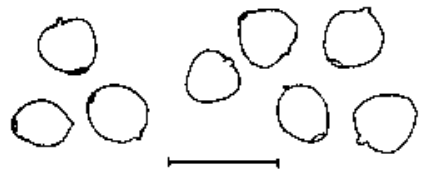

B

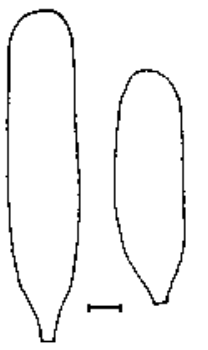

$\mathrm{E}$

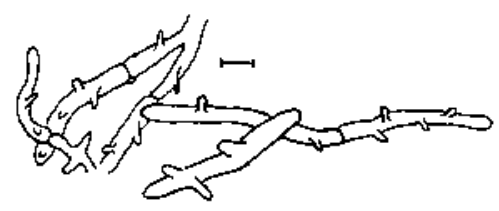

Fig. 9. Coprinopsis argentea microcharacters: A - cheilocystidia, B - pleurocystidia, C - basidia, $\mathrm{D}-$ spores, $\mathrm{E}-$ veil. Scale bars $=10 \mu \mathrm{m}$. 
8-14 $\mu \mathrm{m}$. Cheilocystidia cylindrical, ellipsoid to broadly utriform 15-60 $\times 8$-15 $\mu \mathrm{m}$, pleurocystidia oblong ellipsoid to cylindrical 40-70 $\times 12-20 \mu \mathrm{m}$. Veil composed from diverticulate, thin-walled hyphae, 3-10 $\mu \mathrm{m}$ wide.

LocAlities: Bieszczady Mts, Bieszczady National Park, Wołosate, along the road to Beskid pass; ATPOL: GG-70. A dozen of basidiocarps were found on dead grasses at the road-side; 19.07.2008; leg. B. Gierczyk, det. B. Gierczyk, A. Kujawa; ZBŚRiL 1/BdPN/190708, BGF/080719/0001 (locality mentioned by Gierczyk et al. 2009).

Distribution, HABITAT AND REMARKS: Hitherto species known only from type collection from Great Britain and few localities in Hungary (Nagy 2007), in Poland found only in Bieszczady Mts (Gierczyk et al. 2009). Its habitat is unknown, type specimens were found in grassland, probably in association with grass stems. Descriptions available in the literature are not complete. According to Uljé (http:// users.raketnet.nl/keesuljee/argenteus.htm), the holotype is in poor state, without conserved lamellae. Therefore some characters (basidia and cystidia) of the collected specimens could not be compared with these of the type collection. Spores presented by Orton and Watling (1979) differ slightly in shape from those drew by Uljé (http://users.raketnet.nl/keesuljee/argenteus.htm) during holotype examination - the latter author has shown more lentiform and ellipsoid spores. The specimens collected in Bieszczady Mts have only few kernel of maize shaped spores, most of them are broadly ellipsoid to lentiform, however other characters - the small dimensions of spores, the presence of thin-walled, white veil and ecology betoken that they belong to this species.

Coprinopsis candidata (Uljé) Noordel. (Coprinus candidatus Uljé)

Fig. 10

DESCRIPTION AND ICONOGRAPHY: Uljé (2005): 98, Fig. 107.

Macroscopic AND Microscopic FeATURes: Medium-sized species. Pileus up to 20 $\mathrm{mm}$, ovoid to subglobose, stipe $50 \times 1.5 \mathrm{~mm}$. Cap white to pale cream, covered with a powdery to hairy-floccose veil, stipe white, floccose. Spores red-brown, 8.0-9.0 $\times$ 5.0-5.5 $\mu \mathrm{m}$ (lit. 7.5-11.5 $\times$ 4.5-6.0 $\mu \mathrm{m}$ ), ellipsoid with \pm parallel sides and somewhat conical base and rounded apex, germ pore central. Basidia 4-spored, 17-30 × 8-10 $\mu \mathrm{m}$ (lit. 15-35 × 7-10 $\mu \mathrm{m}$ ). Cheilocystidia 25-40 $\times 15-20 \mu \mathrm{m}$ (lit. up to $40 \times 25 \mu \mathrm{m}$ ), utriform, broadly lageniform to subglobose; pleurocystidia absent. Veil consists of colourless, smooth or slightly granular globose cells, up to $50 \mu \mathrm{m}$ wide. Clamp-connections present.

Localities: Białowieża Primeval Forest, Białowieża National Park, compartment no. 370C; ATPOL: GC-55. A few basidiocarps were found on a fragment of

A

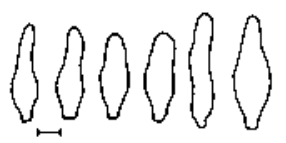

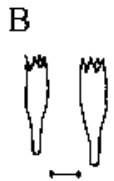

C

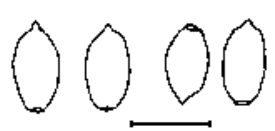

$\mathrm{D}$

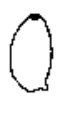

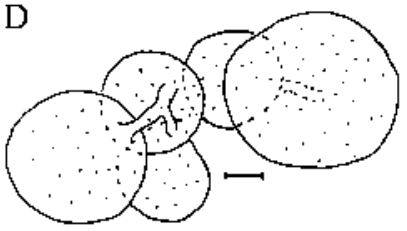

Fig. 10. Coprinopsis candidata microcharacters: A - cheilocystidia, B - pleurocystidia, C - basidia, D - spores, E - veil. Scale bars $=10 \mu \mathrm{m}$. 
deciduous wood, on the ground in Tilio-Carpinetum forest; 19.09.2009; leg., det. B. Gierczyk; BGF/090919/0003.

DISTRIBUTION, HABITAT AND REMARKS: Rare species of poorly known distribution, known from Iceland, Denmark, Norway, Sweden and Netherlands, growing solitary on soil or fallen twigs, sometimes on old dung. A species new to Poland.

\section{Coprinopsis cordispora (T. Gibbs) Noordel. (Coprinus cordisporus T. Gibbs)}

DESCRIPTION AND ICONOGRAPHY: Uljé (2005): 99-100, Fig. 110; Orton, Watling (1979): 66-67, 134-135, Fig. 126, 134, 137.

Localities: 1. Kaczawskie Mts, “Góra Miłek” reserve near Wojcieszów village, ATPOL: BE-61. A dozen of basidiocarps on horse dung in beech forest belonging to Cephalanthero-Fagenion alliance were found; 03.10.2008; leg., det. B. Gierczyk; BGF081003/0010. 2. Bieszczady Mts, Bieszczady National Park, spruce coppice near the camping in Wetlina village; ATPOL: FG-68. A few individuals grew on horse dung; 23.06.2009, 06.10.2009, 05.06.2010; leg. T. Pachlewski, B. Gierczyk, det. B. Gierczyk; BGF/090623/0001, BGF/091006/0003 (obtained in laboratory culture), BGF/100605/0012, BGF/100605/0013. 3. Białowieża Primeval Forest, Białowieża National Park, compartment no. 345B; ATPOL: GC-56. A few basidiocarps were found on deer dung; leg. A. Szczepkowski, det. B. Gierczyk; BGF/091018/0003 (obtained in laboratory culture).

DISTRIBUTION AND REMARKS: The specimens obtained in laboratory culture on dung have slightly smaller spores dimensions than that produced by basidiocarps growing in natural conditions $(5-7 \times 4-6 \mu \mathrm{m}$ vs. $7-11 \times 6-10 \mu \mathrm{m})-$ such effect was not observed for other ink-caps. The species rather common in Europe, found in Netherlands, Scandinavian Countries and Great Britain, growing on dung of various animals. In Poland, mentioned only from three localities: Kraków, Kuźnica Białostocka and horse stud in Wołosate village in Bieszczady National Park (Skirgiełło 1946; Wojewoda 1996; Gierczyk et al. 2009), probably overlooked because of small dimensions.

\section{Coprinopsis cortinata (J.E. Lange) Noordel. (Coprinus cortinatus J.E. Lange)}

Description AND ICONOGRAPHY: Uljé (2005): 98-99, Fig. 108; Orton, Watling (1979): 61-62, 132-133, Fig. 115, 119, 123; Ludwig (2007a): 88, Tabl. 274, Fig. 93.82; Ludwig (2007b): 242-243; Moser (2002): III/ Coprinus/16; Breitenbach, Kränzlin (1995): Vol. 4, Fig. 271

Localities: Kaczawskie Mts, “Góra Miłek” reserve near Wojcieszów village, SW slope of Miłek Hill; ATPOL: BE-61. Two basidiocarps grew on the ground, in the calciferous grassland on the beech forest margin, under shrubs composed of undergrowth of Fagus sylvatica, Acer sp. and Populus sp.; 03.10.2008; leg. B. Gierczyk, M. Wójtowski, T. Pachlewski, det. B. Gierczyk; BGF081003/0008.

DisTRIBUTION AND REMARKS: This rather rare species was recorded from scarce localities in Netherlands, Great Britain, Denmark, Finland and Sweden, growing on soil (often calcareous) in lawn. It is probably overlooked. Until now it has been found in eight localities in Poland (Wojewoda 2003; Bujakiewicz 2004; Nita, Bujakiewicz 2007; Bujakiewicz, Springer 2009; Kujawa 2009; Nita, Bujakiewicz 2009; Bujakiewicz 2010; Bujakiewicz, Kujawa 2010). 
Coprinopsis cothurnata (Godey) Redhead, Vilgalys \& Moncalvo (Coprinus corhurnatus Godey)

Fig. 11, Phot. 4

DeSCRIPTION AND ICONOGRAPHY: Uljé (2005): 95, Fig. 102; Orton, Watling (1979): 66, 134-135, Fig. 127, 136; Ludwig (2007a): 88, Tabl. 274, Fig. 93.80; Ludwig (2007b): 240-241; Moser (2002): III/Coprinus/16; Doveri (2004): 170-173.

MACROSCOPIC AND MICROSCOPIC FEATURES: Basidiocarps medium-sized with cap up to $35 \mathrm{~mm}$, ellipsoid, conical to convex; stipe up to $100 \times 3-5 \mathrm{~mm}$. Cap covered with white, minutely granular, powdered veil, stipe white, slightly flocculose. Spores 12.0-13.0 × 7.0-7.5 × 7.0 um (lit. 9.5-15.5 × 6.5-8.5 × 7.0-7.5 $\mu \mathrm{m}$ ), oblongly ellipsoid (with parallel sides) to hexangular, with central to slightly eccentric germ pore, dark red-brown. Basidia 4-spored, 25-40 × 9-12 $\mu \mathrm{m}$ (lit. 18-50 × 9-13 $\mu \mathrm{m}$ ). Cheilocystidia globose to subglobose, $25-60 \times 20-45 \mu \mathrm{m}$ (lit. 30-80 $\times 15-50 \mu \mathrm{m}$ ); pleurocystidia similar, sparse. Veil composed from smooth, globose, up to $80 \mu \mathrm{m}$ wide elements, mixed with scarce diverticulate hyphae.

Localities: Bieszczady National Park, horse stud in Wołosate village, ATPOL: FG-79. A few fruitbodies were found on horse dung mixed with straw; 26.06.2009, 01.06.2010, 05.06.2010; leg. T. Pachlewski, A. Kujawa, B. Gierczyk, det. B. Gierczyk; BGF/090626/0004, BGF/100601/0006, BGF/100601/0007, BGF/100605/0007.

DistRIBUTION, HABITAT AND REMARKS: Rare European species, but in some countries (e.g., Netherlands) quite common, found mainly on cow and horse dung or rotting straw, solitary to subfasciculate. Probably widely distributed but overlooked. Hitherto not recorded in Poland.
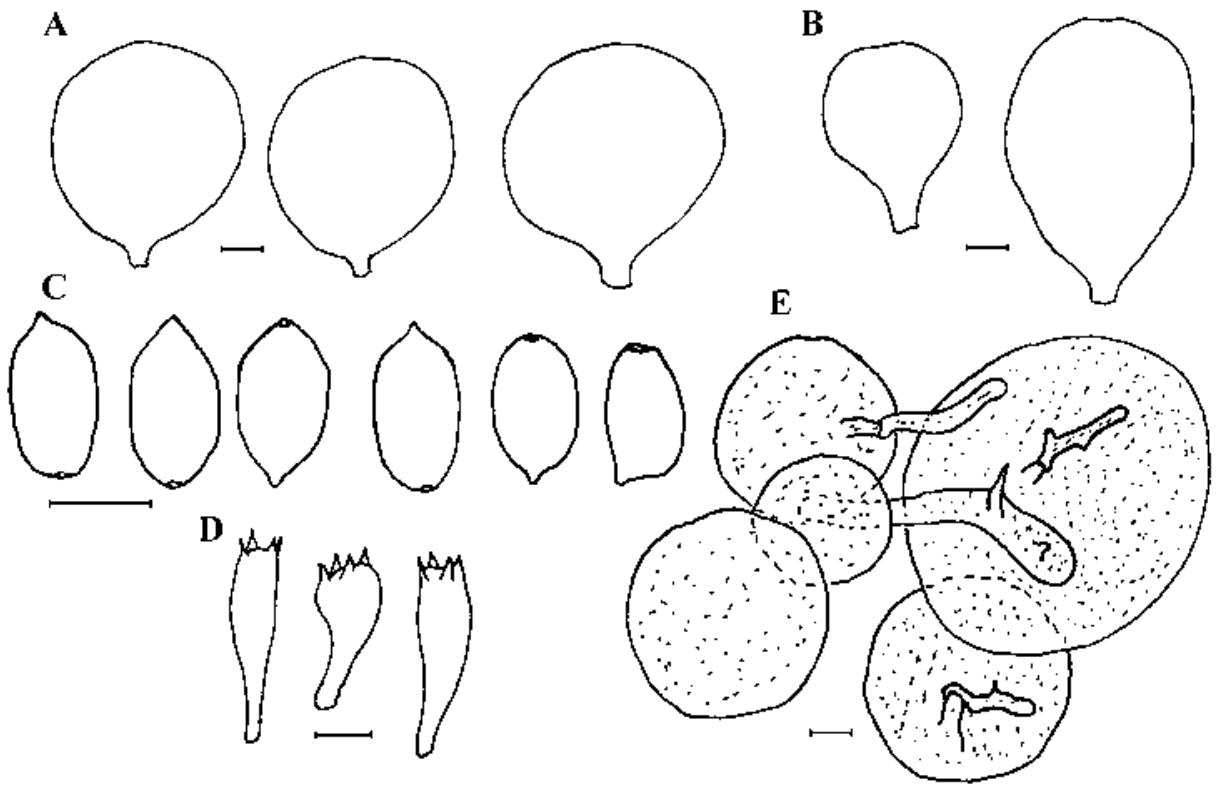

Fig. 11. Coprinopsis cothurnata microcharacters: A - cheilocystidia, B - pleurocystidia, $\mathrm{C}$ - spores, D - basidia, E - veil. Scale bars $=10 \mu \mathrm{m}$. 
Coprinopsis echinospora (Buller) Redhead, Vilgalys \& Moncalvo (Coprinus echinosporus Buller)

Fig. 12

Description And ICONOGRAPHY: Uljé (2005): 84, Fig. 85; Orton, Watling (1979): 35-35, 124-125, Fig. 52a\&b; Ludwig (2007a): 71, Tabl. 257, Fig. 93.10A-C; Ludwig (2007b): 158-159; Moser (2002): III/Coprinus/10; Breitenbach, Kränzlin (1995): Vol. 4, Fig. 274.

MACROSCOPIC AND MICROSCOPIC FEATURES: Basidiocarps small, pileus up to 10-30 $\mathrm{mm}$, first ellipsoid to ovoid, then convex, whitish to greyish, stipe up to $100 \times 1-3 \mathrm{~mm}$. Veil on cap form a white to grey, fibrillose scales. Spores 8.5-10.5 × 6.0-7.0 $\mu \mathrm{m}$ (lit. 8.5-12.0 $\times 6.0-8.0 \mu \mathrm{m}$ ), amygdaliform, very dark brown, with warty ornamentation and central germ pore. Basidia 4-spored, 18-30 × 8-9 $\mu \mathrm{m}$ (lit. 16-38 × 8-9.5 $\mu \mathrm{m}$ ). Cystidia not seen (lit.: cheilocystidia subglobose, utriform to cylindrical, 25-100 $\times 20-55 \mu \mathrm{m}$; pleurocystidia ellipsoid, oblong to subcylindrical 60-120 $\times 20-50(80) \mu \mathrm{m})$. Veil composed of thin-walled, diverticulate hyphae, $2-8 \mu \mathrm{m}$ wide. Clamp-connections present.

LOCALITIES: $1.5 \mathrm{~km}$ SW from Wrząca village near Piła; ATPOL: BC-26. One basidiocarp was found on old fruitbody of Calvatia excipuliformis, in mixed forest (Pinus sylvestris, Betula verrucosa, Quercus sp.); 11.01.2006; leg. R. Puciata, det. B. Gierczyk; BGF/060111/0001.

DistRIBUTION, HABITAT AND REMARKs: Widespread but not common European inkcap species. Known from Netherlands, Norway, Finland, Sweden, Denmark, Great Britain and other countries, growing solitary on wood. Overlooked because of the small basidiocarps. Not mentioned from Poland so far.

A

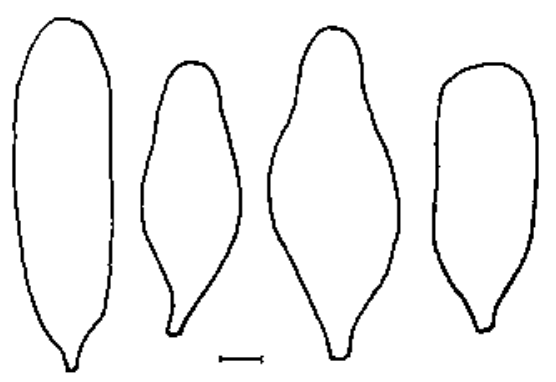

B

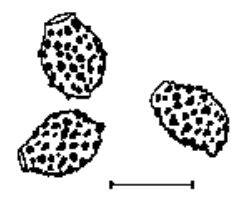

C

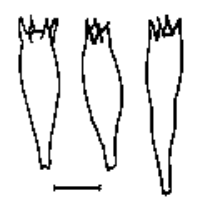

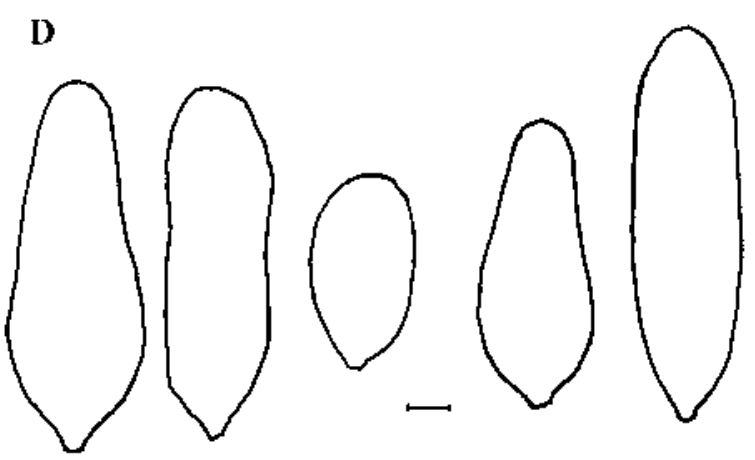

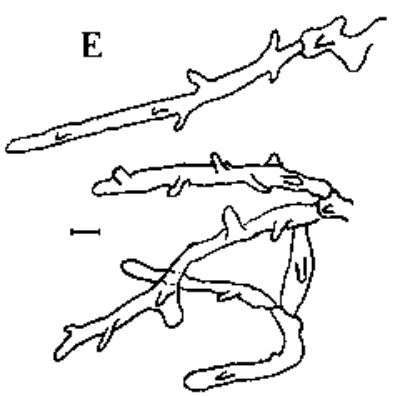

Fig. 12. Coprinopsis echinospora microcharacters: A - cheilocystidia, B - spores, C - basidia, D - pleurocystidia, E - veil. Cheilo- and pleurocystidia presented according to Uljé (2003) and Orton \& Watling 1979. Scale bars $=10 \mu \mathrm{m}$. 
Coprinopsis episcopalis (P.D. Orton) Redhead, Vilgalys \& Moncalvo (Coprinus episcopalis P.D. Orton)

Fig. 13, Phot. 5

DESCRIPTION AND ICONOGRAPHY: Uljé (2005): 79-80; Orton, Watling (1979): 37-38, 120-121, 124-125, Fig. 26, 53, 57-59; Ludwig (2007a): 89, Tabl. 275, Fig. 93.87; Ludwig (2007b): 247-248; Breitenbach, Kränzlin (1995): Vol. 4, Fig. 276

MACROSCOPIC AND MICROSCOPIC FEATURES: Basidiocarps medium-sized, pileus up to $50 \mathrm{~mm}$, first obtusely conical, then conical to convex, first white then greyish. Veil forming white patches with brown centre. Stipe 70-80 $\times 5-7 \mathrm{~mm}$, white. Spores 7.5$10.0 \times 6.0-9.5 \mu \mathrm{m}$ (lit. $(6.5) 8.0-10.5(11.5) \times 6.0-9.0(11.0) \mu \mathrm{m})$, quadrangular with rounded angles and distinct, truncate, apical papilla, central germ pore and dark red-brown color. Basidia 4-spored, 20-35 × 9-11 $\mu \mathrm{m}$ (lit. 17-35 × 10-11 $\mu \mathrm{m}$ ). Cheilocystidia subglobose, ellipsoid, oblong or utriform, 35-110 × 12-45 um (lit. 30-120 $\times$ 10-40 $\mu \mathrm{m}$ ). Pleurocystidia subcylindrical, oblong, ellipsoid to utriform, 45-130 $\times 20$ $40 \mu \mathrm{m}$ (lit. 50-140 $\times 15-40 \mu \mathrm{m}$ ). Veil composed of thin-walled, slightly diverticulate hyphae, 2-12 $\mu \mathrm{m}$ wide, with minute incrustation, intermixed with yellowish, slightly thick-walled elements. Clamp-connections present.

LoCALITIES: Near Bukrzyno Małe lake, $1 \mathrm{~km} \mathrm{~N}$ from Stare Czaple village; ATPOL: CA-96. One basidiocarp was found on calcareous soil in beech forest; 28.10.2009; leg. D. Karasiński, det. D. Karasiński \& B. Gierczyk; BGF/BF/091028/0001.

Distribution, HABITAT AND REMARKS: Very rare European species, known from England, Germany, Norway and Finland, found on decayed, deciduous leaves (mostly Fagus) on calcareous soil. The basidiocarps resemble small specimens of C. picaceus. Hitherto not mentioned from Poland.

A

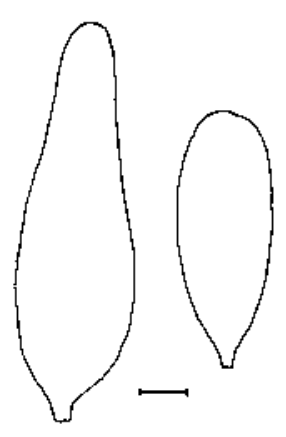

C

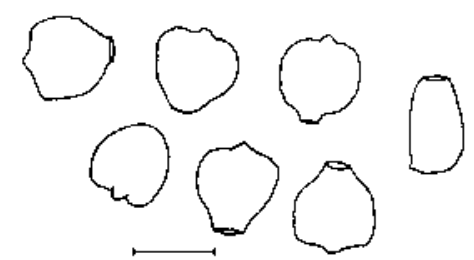

B
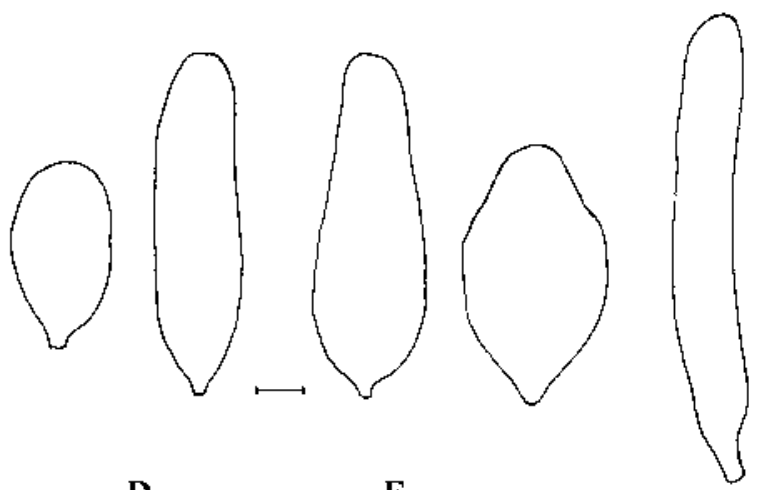

D

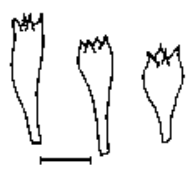

E
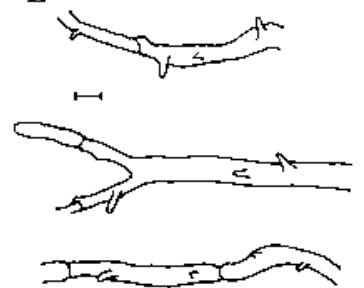

Fig. 13. Coprinopsis episcopalis microcharacters: A - cheilocystidia, B - pleurocystidia, $\mathrm{C}$ - spores, D - basidia, E - veil. Scale bars $=10 \mu \mathrm{m}$. 
Coprinopsis erythrocephala (Lév.) Redhead, Vilgalys \& Moncalvo (Coprinus erythrocephalus Lév.)

Description AND iconography: Uljé (2005): 60, Fig. 49; Orton, Watling (1979): 34-35, 124-125, Fig. 50, 56; Ludwig (2007a): 80, Tabl. 266, Fig. 93.53A\&B; Ludwig (2007b): 206-207.

Localities: Manorial park around the Habsburgs Palace in Żywiec village; ATPOL: DG-04. A few basidiocarps were found on the soil mixed with wood chips, in depression, under Quercus sp.; 18.11.2009; leg. R. Taran, det. B. Gierczyk; BGF/ BF/091118/0001.

Distribution, HABITAT AND REMARKs: Widespread but rather rare European species. It grows gregariously on wood-chips in moist, nitrogen rich places. Hitherto known from four localities in Poland (Wojewoda 2003; Kujawa 2009).

Coprinopsis foetidella (P.D. Orton) Noordel. (Coprinus foetidellus P.D. Orton)

Fig. 14, Phot. 6

DesCriPtion AND ICONOGRAPHY: Uljé (2005): 104, Fig. 118; Orton, Watling (1979): 76-77, 138-139, Fig. 157, 159; Ludwig (2007a): 84, Tabl. 270, Fig. 93.63; Ludwig (2007b): 219-220.

MACROSCOPIC AND MICROSCOPIC FEATURES: Basidiocarps small, pileus up to $9 \mathrm{~mm}$, first subglobose to oblong, then broadly conical, densely covered with mealy, mousegrey veil. Stipe $20-30 \times 0.5-1.5 \mathrm{~mm}$, whitish. Smell of basidiocarps strong, narcotic, resembling that of $C$. narcoticus. Spores 7.5-11.0 × 4.5-6.5 $\mu \mathrm{m}$ (lit. 7.5-11.0 $\times$ 4.5-7.0 $\mu \mathrm{m})$, ellipsoid to ovoid, with rounded apex and base, central germ pore and dark red-brown color, covered with sparse, smooth myxosporium. Basidia 4-spored, 20-22 $\times 7-9 \mu \mathrm{m}$ (lit. 18-20 × 6-8 $\mu \mathrm{m})$. Cheilocystidia subglobose, ellipsoid, oblong to utriform, $25-60 \times 15-20 \mu \mathrm{m}$ (lit. 20-50 $\times 14-22 \mu \mathrm{m}$ ). Pleurocystidia oblong to utriform, $60-95 \times 20-30 \mu \mathrm{m}$ (lit. 50-90 $\times 18-30 \mu \mathrm{m}$ ). Veil composed of globose, up to $90 \mu \mathrm{m}$ wide elements, covered with distinct warts, and sparse, diverticulate, narrow hyphae. Clamp-connections absent.

Localities: Bieszczady National Park, horse stud in Wołosate village; ATPOL: FG-79. A dozen of fruitbodies were found on horse dung mixed with straw; 01.05.2010; leg. D. Karasiński, det. B. Gierczyk; BGF/100601/0010.

A
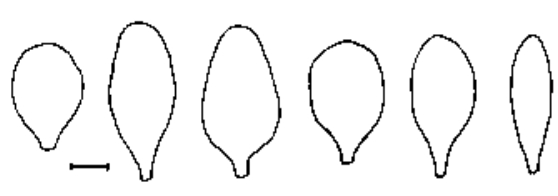

$\mathrm{B}$

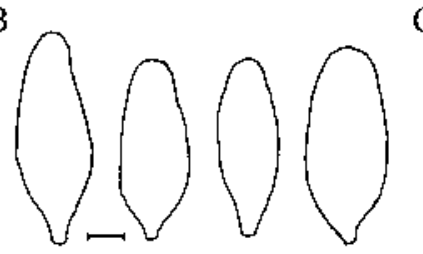

C

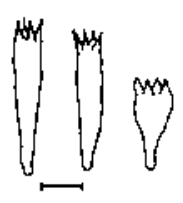

D

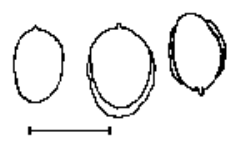

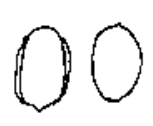

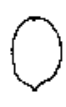

F

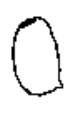

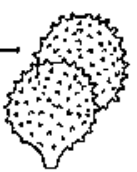

Fig. 14. Coprinopsis foetidella microcharacters: A - cheilocystidia, B - pleurocystidia, C - basidia, D - spores, E - veil. Scale bars $=10 \mu \mathrm{m}$. 
DistRIBUTION, HABITAT AND REMARKS: Known only from Europe, very rare, found in Netherlands, Great Britain, Norway and Sweden. It grows on herbivores dung, often on dung mixed with straw. Hitherto not mentioned from Poland.

Coprinopsis geesterani (Uljé) Redhead, Vilgalys \& Moncalvo (Coprinus geesteranii Uljé)

Fig. 15

DESCRIPTION AND ICONOGRAPHY: Uljé (2005): 63, Fig. 54.

MACROSCOPIC AND MICROSCOPIC FEATURES: Basidiocarps small, pileus up to $27 \mathrm{~mm}$, ellipsoid, ovoid to subglobose, then flat, first white, becoming grey to ochraceousgrey with age. Veil radially splitting into fibrillose or hairy flocks. Stipe $15-45 \times 1-2$ $\mathrm{mm}$, white, flocculose. Spores 7.5-8.5 × 5.0-6.0 $\mu \mathrm{m}$ (lit. 5.5-10.5 $\times$ 4.5-7.0 $\mu \mathrm{m}$ ), ellipsoid, ovoid to somewhat mitriform to rhomboid, with conical base, central germ pore and red-brown color. Basidia 4-spored, 22-30 × 6-10 $\mu \mathrm{m}$ (lit. 18-32 × 7-11 $\mu \mathrm{m}$ ). Cheilocystidia utriform, clavate, sometimes ellipsoid to subglobose, 30-80 $\times 20-36$ $\mu \mathrm{m}$ (lit. 25-105 $\times 12-40 \mu \mathrm{m}$ ). Pleurocystidia elongate ellipsoid, ovoid to fusiform, 65$120 \times 25-30 \mu \mathrm{m}$ (lit. 70-125 × 22-33 um). Veil composed of elongated hyphae 30-120 $\times 10-30 \mu \mathrm{m}$, constricted at septa. Clamp-connections present.

LocAlities: $1.2 \mathrm{~km}$ S from Lusówko village near Poznań, the forest along a red bicycle route on the S bank of Lusowskie lake; ATPOL: BD-07. A few basidiocarps were found on decaying grass; 26.07.2009; leg., det. B. Gierczyk; BGF/090726/0001, BGF/090726/0002. 2. Podstolice near Września, by the road to Opatówko village; ATPOL: CD-12. A few basidiocarps were found on vegetable refuse (mainly corncob fragments); 26.04.2009; leg., det. B. Gierczyk; BGF/090426/0001.

DistRIBUTION, HABITAT AND REMARKS: Hitherto the species was known only from Netherlands, where it is rather common. It grows solitary on soil, decaying woodchips or composted vegetable refuse. Probably not distinguished from other, similar
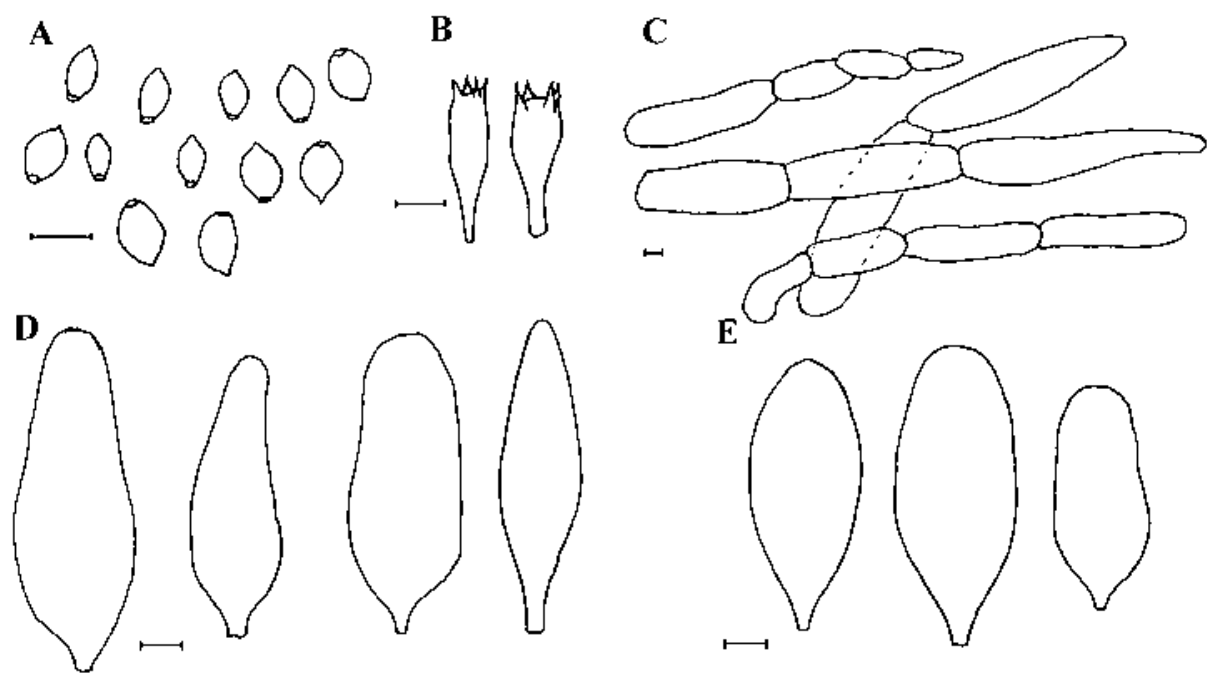

Fig. 15. Coprinopsis geesterani microcharacters: A - spores, B - basidia, C - veil, D - cheilocystidia, E - pleurocystidia. Scale bars $=10 \mu \mathrm{m}$. 
species from the section Lanatuli J. Lange: Coprinopsis jonesii (Peck) Redhead, Vilgalys \& Moncalvo and C. pseudoradiata (Watling) Redhead, Vilgalys \& Moncalvo. The former is characterized by larger basidiocarps, slightly broader spores, without tendency to have rhomboid shape and a habitat (mainly on burnt places and woodchips). The latter species has predominantly ellipsoid spores with parallel sides, shorter cystidia and grows mainly on dung. A species new to Poland.

Coprinopsis gonophylla (Quél.) Redhead, Vilgalys \& Moncalvo (Coprinus gonophyllus Quél.)

Fig. 16

Description AND ICONOGRAPHY: Uljé (2005): 78, Fig. 75; Orton, Watling (1979): 46-47, 128-129, Fig. 93, 94; Ludwig (2007a): 90, Tabl. 276, Fig. 93.92A\&B; Ludwig (2007b): 252-253; Breitenbach, Kränzlin (1995): Vol. 4, Fig. 278

MACROSCOPIC AND MICROSCOPIC FEATURES: Basidiocarps medium-sized, pileus up to $30 \mathrm{~mm}$, first globose, then hemispheric to conical, finally convex, white to greyish, stipe up to $60 \times 1-3 \mathrm{~mm}$, whitish. Veil white, covering whole pileus, breaking into patches and becoming brownish with age. Spores short ovoid to subglobose, flattened, 7.0-8.5 $\times$ 6.5-8.0 × 5.5-6.0 $\mu \mathrm{m}$ (lit. 6.0-8.5 × 5.5-8.0 × 5.0-6.5 $\mu \mathrm{m})$, very dark brown to black, with central germ pore, rounded at the base and truncated at the apex. Basidia 4-spored, 15$30 \times 7-9 \mu \mathrm{m}$ (lit. 12-34 × 7-9 $\mu \mathrm{m}$ ). Hymenial cystidia not seen (according to literature cheilocystidia subcylindrical, oblong, ellipsoid, fusiform to subutriform, 40-85 × 25-45 $\mu \mathrm{m}$; pleurocystidia subcylindrical to oblong or fusiform, 50-120 $\times 20-40 \mu \mathrm{m})$. Veil composed of thin-walled, diverticulate, 3-7 $\mu \mathrm{m}$ wide, hyphae. Clamps present.

LocalitiEs: Łany near Wrocław, ATPOL: CE-50. On the sandy and stony meadow near Odra river one basidiocarp grew on a wood-chip; 08.11.2008; leg. B. Gierczyk, T. Pachlewski, det. B. Gierczyk; BGF/081108/0011.

A
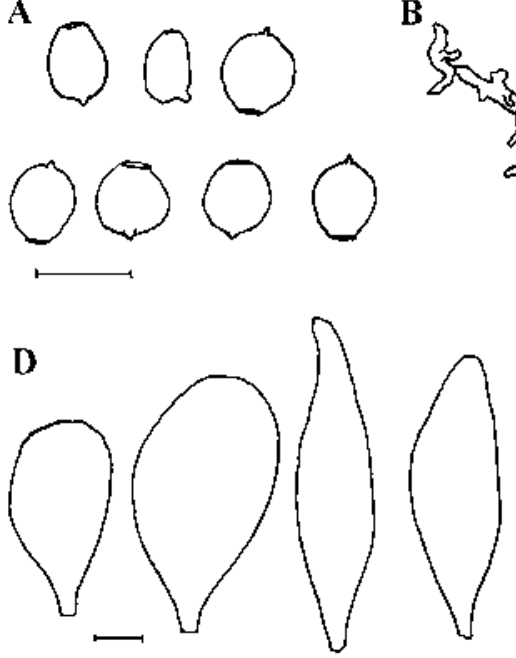

B
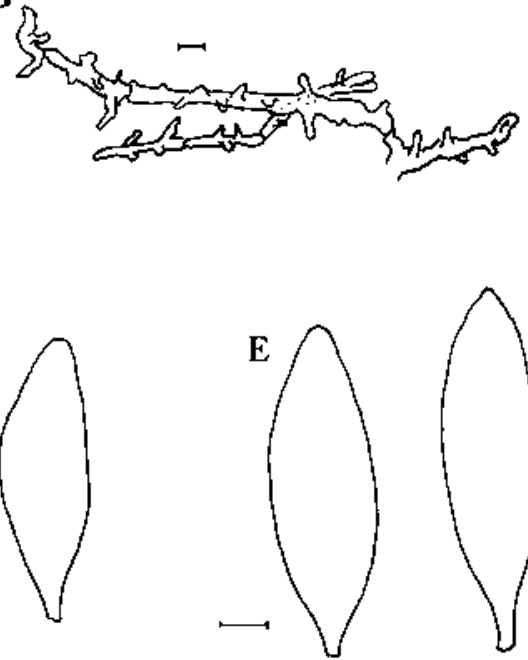

C
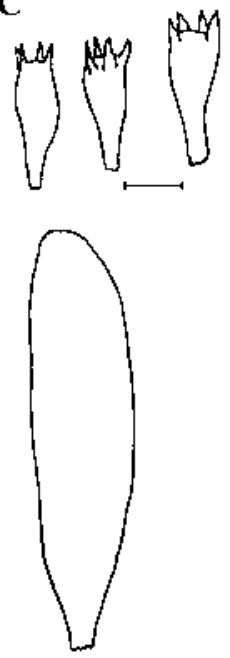

Fig. 16. Coprinopsis gonophylla microcharacters: A - spores, B - veil, C - basidia, D - cheilocystidia, E - pleurocystidia. Cheilo- and pleurocystidia presented according to Uljé (2003) and Orton \& Watling (1979). Scale bars $=10 \mu \mathrm{m}$. 
Distribution, HABITAT AND REMARKs: Widespread but rare in Europe. Known from Netherlands, Great Britain and Scandinavian Countries. It grows solitary or fasciculate on burnt places or bare, clayey soil. A species new to Poland.

Coprinopsis insignis (Peck) Redhead, Vilgalys \& Moncalvo (Coprinus insignis Peck; C. alopecia Lasch s. auct.)

Fig. 17

Description AND ICONOGRAPHy: Uljé (2005): 58-59, Fig. 46; Orton, Watling (1979): 33-34; Ludwig (2007a): 70, Tabl. 256, Fig. 93.8 (as C. alopecia); Ludwig (2007b): 156-157 (as C. alopecia); Moser (2002): III/Coprinus/3 (as C. alopecia).

MACROSCOPIC AND MICROSCOPIC FEATURES: Basidiocarps large, pileus up to 100 $\mathrm{mm}$, first subglobose to ellipsoid, then conical, white, covered with fibrillose veil, becoming greyish to grey with age, with ochraceous centre. Stipe $80-150 \times 4-12 \mathrm{~mm}$, white, with clavate base. Spores 11.5-14.0 × 6.5-8.0 $\mu \mathrm{m}$ (lit. 11.0-14.5 × 6.5-8.5 $\mu \mathrm{m})$, amygdaloid, with rounded or slightly conical base and apical papilla, covered with warts, blackish, germ pore central. Basidia 4-spored, 28-45 × 9-10 $\mu \mathrm{m}$ (lit. 25-42 $\times$ 8-10 $\mu \mathrm{m}$ ). Cheilocystidia utriform to cylindrical, 50-170 $\times$ 30-65 $\mu \mathrm{m}$ (lit. 50-160 $\times$ 30-60 $\mu \mathrm{m}$ ), pleurocystidia of the same shape, 85-185 $\times$ 38-50 $\mu \mathrm{m}$ (lit. 80-180 $\times 35-50$ $\mu \mathrm{m})$. Veil composed of cylindrical hyphae, 40-135 × 6-15 $\mu \mathrm{m}$ (lit. 20-125 × 7-14 $\mu \mathrm{m}$ ). Clamps present.
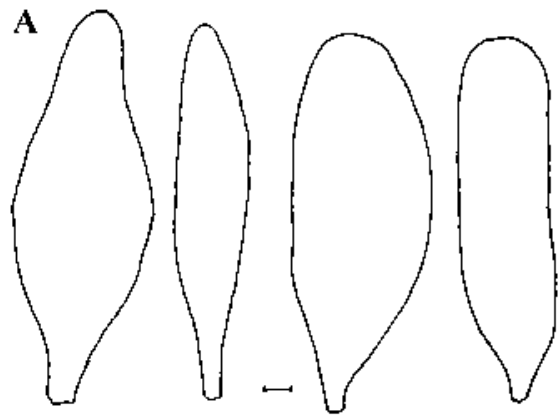

C

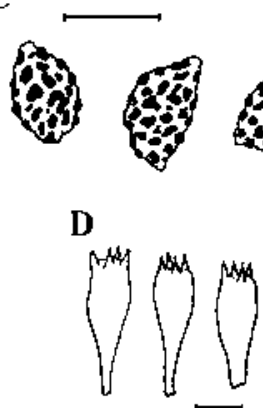

B
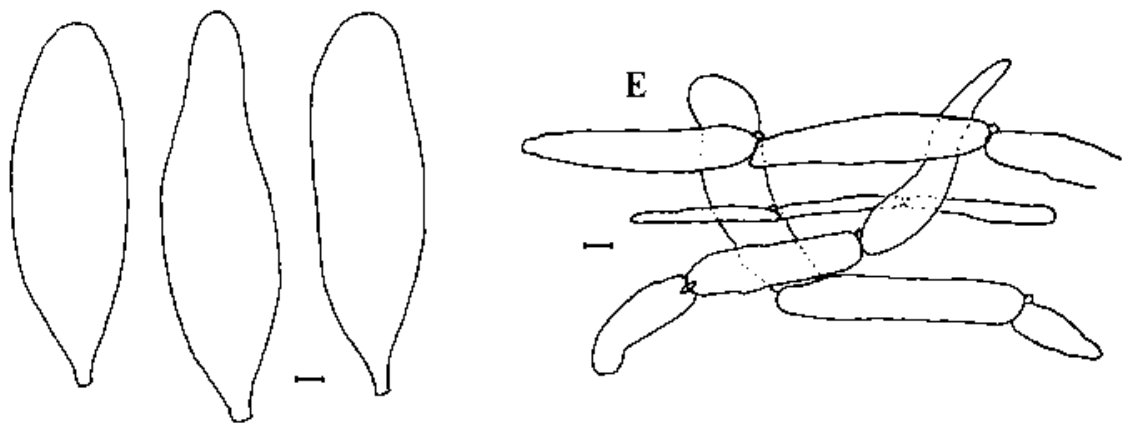

Fig. 17. Coprinopsis insignis microcharacters: A - cheilocystidia, B - pleurocystidia, C-spores, $\mathrm{D}$ - basidia, $\mathrm{E}$ - veil. Scale bars $=10 \mu \mathrm{m}$. 
Localities: 1. Białowieża Primeval Forest, Białowieża National Park, compartment no. 370; ATPOL: GC-55. About 10 basidiocarps were found on the ground, in Tilio-Carpinetum, near the stump of Acer pseudoplatanus; 16.09.2009; leg. G. Domian, det. B. Gierczyk; BGF/090916/0002. 2. Białowieża Primeval Forest, Białowieża National Park, compartment no. 371; ATPOL: GC-55. A few fruitbodies grew on the ground, at the base of the Acer pseudoplatanus trunk, in the Tilio-Carpinetum forest; 16.09.2009; leg., det. B. Gierczyk; BGF/090916/0001. 3. Białowieża Primeval Forest, compartment no. 451; ATPOL: GC-65. A fascicle composed of over ten basidiocarps was found near Quercus sp. stump, in mixed forest; 14.09.2009; leg. G. Domian, det. A. Kujawa; BGF/090914/0001. 4. Białowieża Primeval Forest, compartment no. 698; ATPOL: GC-74. A few basidiocarps were found near the trunk of a deciduous tree; 18.09.2009; leg. G. Domian, det. B. Gierczyk; BGF/090918/0004.

DistRIBUTION, HABITAT AND REMARKs: Very rare ink-cap species known from North America and Europe. Found in the Netherlands and Scandinavian countries, occurring fasciculate (rarely solitary) on or near the stumps, rarely on the ground. In Poland, known only from Dezydery Chłapowski Landscape Park (Kujawa 2009).

Coprinopsis jonesii (Peck) Redhead, Vilgalys \& Moncalvo (Coprinus jonesii Peck)

Fig. 18

Description AND ICONOGRAPHy: Uljé (2005): 62-63, Fig. 52\&53; Orton, Watling (1979): 41, 126-127, Fig. 60, 69 (as Coprinus lagopides); Ludwig (2007a): 80, Tabl. 266, Fig. 93.51A-C; Ludwig (2007b): 204205; Breitenbach, Kränzlin (1995): Vol. 4, Fig. 287 (as Coprinus lagopides).

MACROSCOPIC AND MICROSCOPIC FEATURES: Basidiocarps large, cap up to $60 \mathrm{~mm}$, first ellipsoid to narrowly conical, then applanate, stipe 50-130 $\times 3-10 \mathrm{~mm}$. Pileus

A

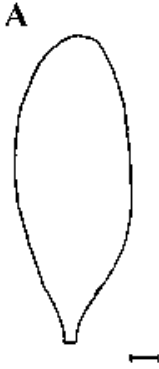

C

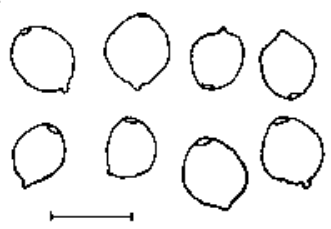

B

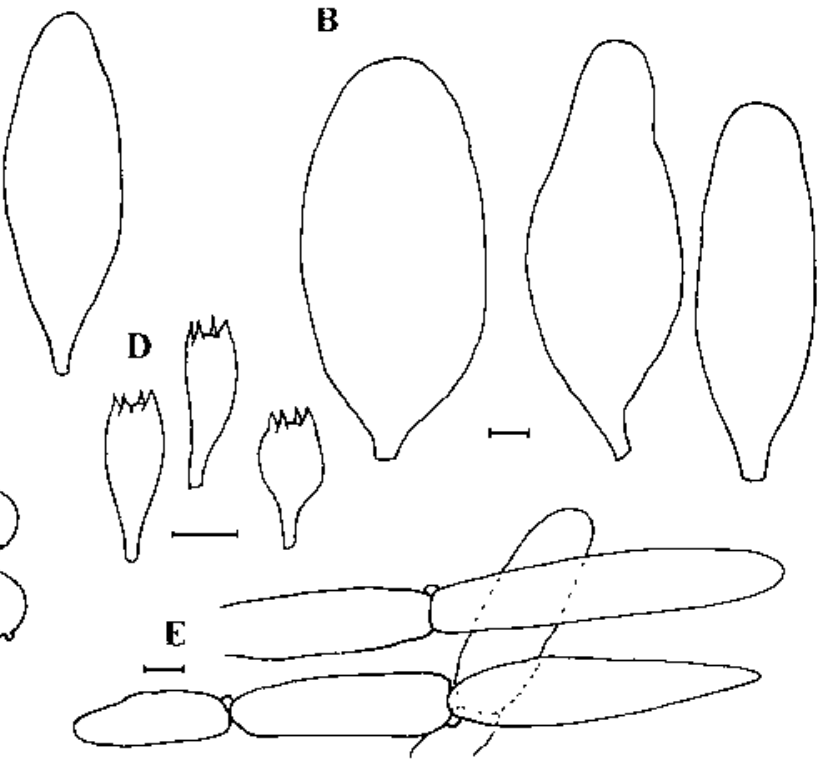

Fig. 18. Coprinopsis jonesii microcharacters: A - cheilocystidia, B - pleurocystidia, C-spores, $\mathrm{D}$ - basidia, E - veil. Scale bars $=10 \mu \mathrm{m}$. 
grey-brown in centre, paler to margin, with whitish floccose veil. Spores 7.0-8.5 $\times$ 6.0-7.0 $\mu \mathrm{m}$ (lit. 6.5-9.5 $\times$ 6.0-8.0 $\mu \mathrm{m}$ ), ellipsoid to ovoid, dark red-brown, with rounded base and apex and central germ pore. Basidia 4-spored 15-35 × 8-10 $\mu \mathrm{m}$ (lit. 16$40 \times 7-9 \mu \mathrm{m}$ ). Cheilocystidia (sub)globose to oblong, 35-75 $\times 17-45 \mu \mathrm{m}$ (lit. 35-85 $\times 15-50 \mu \mathrm{m})$. Pleurocystidia subglobose, oblong to utriform or cylindrical, 55-120 $\times$ 25-48 $\mu \mathrm{m}$ (lit. 50-140 × 20-55 $\mu \mathrm{m}$ ). Veil composed of elongate, sausage-like elements

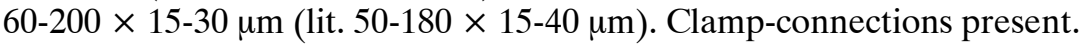

Localities: 1. "Puszcza Bukowa" forest, Gryfino Forest District, compartment 347d; ATPOL: AB-94. A dozen of basidiocarps grew in the hollow in the trunk of Salix sp. three, on the margin of deciduous forest (Salix sp., Alnus sp., Fagus sylvatica); 12.12.2009; leg. G. Domian, det. B. Gierczyk; BGF/BF/091212/0001. 2. Poznań, western part of "Uroczysko Marcelin" forest, near a Junikowski stream and the black bicycle route; ATPOL: BD-08. A few basidiocarps were found on the burnt place, overgrown with Urtica dioica; 29.08.2009, 15.05.2010; leg., det. B. Gierczyk; BGF/090829/0001, BGF/100515/0002. 3. Hubert reserve near Dąbrówka; ATPOL: CF-19. A few basidiocarps among grasses, around woody pales knocked into the ground; 10.10.2007; leg. J. Lichoń, det. B. Gierczyk; BGF/BF/071010/0001. 4. $1.5 \mathrm{~km} \mathrm{~N}$ from Huta Brudzka village; ATPOL: DE-35. A dozen of basidiocarps were found around the trunk and fallen deciduous tree, in the forest margin; 10.04.2010; leg. J. Nowicki, det. B. Gierczyk; BGF/BF/100412/0002. 5. Złoty Potok village near Częstochowa; ATPOL: DE-96. One basidiocarp on old trunk, in beech forest; 04.10.2009; leg. K. Kołodziejczyk, det. B. Gierczyk; BGF/BF/091004/0002. 6. Suchedniowsko-Oblęgorski landscape park, near Bliżyn village; ATPOL: EE-45. One basidiocarp on the ground in mixed forest (Pinus sylvestris, Quercus sp.) in peat bog; 15.09.2009; leg. K. Kołodziejczyk, det. B. Gierczyk; BGF/BF/090915/0002. 7. Bieszczady Mts, Bieszczady National Park, SW from the Wołosate village, along the horse-riding trail on the NE slope of Kiczera Mt.; ATPOL: FG-79. One basidiocarp was found in a hollow, scooped out in a beech-tree trunk in beech forest; 23.08.2009; leg. G. Domian, det. B. Gierczyk; BGF/090823/0001.

Distribution, HABITAT AND REMARKs: Species widespread all over the word, rather common. It grows solitary to fasciculate on burnt-places, wood-chips, vegetable refuses, heaps mixed with dung, rotten straw or other plants refuses, sometimes on pure dung. Hitherto not mentioned from Poland. Because of the morphological and ecological similarity to other species of the section Lanatulii J. Lange, doubtful identifications were possible. It is better known under the name Coprinus lagopides $\mathrm{P}$. Karst. Because the type collection of $C$. lagopides shows ornamented spores (and is conspecific with $C$. phlyctidosporus Romagn), which is not in accordance with species description, the name $C$. lagopides should be rejected (Uljé 2005).

Coprinopsis kubickae (Pilát \& Svrček) Redhead, Vilgalys \& Moncalvo (Coprinus kubickae Pilát \& Svrček)

Fig. 19, Phot. 7

Description and iconography: Uljé (2005): 74-75, Fig. 70; Ludwig (2007a): 91, Tabl. 277, Fig. 93.96A7B; Ludwig (2007b): 257-258.

MACROSCOPIC AND MICROSCOPIC FEATURES: Basidiocarps small, pileus up to $15 \mathrm{~mm}$, first subglobose, then broadly conical, ochre-brown, becoming paler with age (grey to grey-brown). Veil forming minute flocci, white-grey. Stipe 25-30 $\times$ 0.5-2 mm, white, 
A

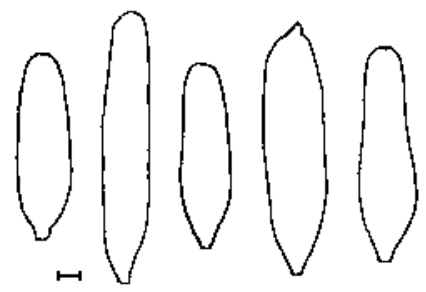

C

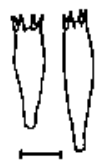

D

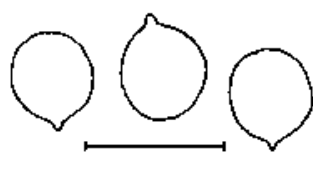

$\mathrm{B}$

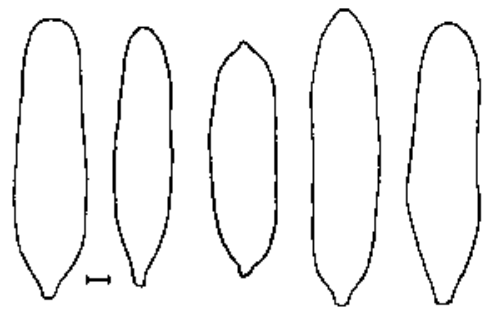

E
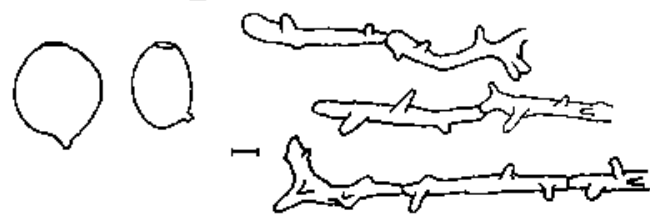

Fig. 19. Coprinopsis kubickae microcharacters: A - cheilocystidia, B - pleurocystidia, C - basidia, D - spores, E - veil. Cheilo- and pleurocystidia presented according to Uljé (2003). Scale bars $=10 \mu \mathrm{m}$.

slightly fibrillose. Spores 7.0-11.0 × 6.0-10.5 um (lit. 7.0-11.5 × 6.0-10.5 $\mu \mathrm{m}$ ), subglobose to broadly ellipsoid, with rounded or slightly conical apex and base, central or slightly eccentric germ pore and red-brown color. Basidia 4-spored, 13-30 × 10-12 $\mu \mathrm{m}$ (lit. 14-36 $\times$ 8-11.5 $\mu \mathrm{m}$ ). Cystidia not seen (according to literature cheilocystidia narrowly utriform, subcylindrical or conical, 35-80(120) $\times 11-20(28) \mu \mathrm{m}$; pleurocystidia utriform to subcylindrical, 55-110(200) $\times 12-20(28) \mu \mathrm{m})$. Veil composed of thin-walled, diverticulate hyphae, up to $7 \mu \mathrm{m}$ wide. Clamp-connections present.

LocalitiEs: Kielce city, pond in the Malinowa street; ATPOL: EE-74. A few basidiocarps were found just above the water level, on dead stems of Typha sp., Glyceria maxima and Acorus calamus growing in the pond; 20.07.2007; leg. M. Fałdziński, det. A. Kujawa, B. Gierczyk; BGF/BF/070720/0001.

Distribution, HABITAT AND REMARKs: Known only from Europe, rarely reported but probably overlooked because of minute basidiocarps. It grows on dead stems of Glyceria, Phragmites, Carex and Juncus, but also in greenhouses on rich soil or decayed straw. Hitherto not mentioned from Poland.

Coprinopsis narcotica (Batsch) Redhead, Vilgalys \& Moncalvo (Coprinus narcoticus (Batsch) Fr.), E

Description and ICONOGRaPhy: Uljé (2005): 107, Fig. 123; Orton, Watling (1979): 69-70, 138-139, Fig. 167

Localities: Poznań, "Uroczysko Marcelin” forest, continuation of the Leśnych Skrzatów street, $200 \mathrm{~m}$ SW from the allotments; ATPOL: BD-08. One basidiocarp was found in the herbaceous thickets at the skirt of a beech-hornbeam forest, on reach soil; 15.08.2009; leg., det. B. Gierczyk; BGF090815/0001.

DISTRIBUTION AND REMARKS: Ink-cap species widespread and common in Europe and other regions, growing on clayey or sandy soil, on compost or dung mixed with vegetable refuse. In Poland found in seven localities (Wojewoda 2003). 
Coprinopsis nivea (Pers.) Redhead, Vilgalys \& Moncalvo (Coprinus niveus (Pers.) Fr.), $\mathbf{R}$

DesCription AND ICONOGRAPHY: Uljé (2005): 92-93, Fig. 100; Orton, Watling (1979): 63-64, 134-135, Fig. 128\&130; Ludwig (2007a): 87, Tabl. 273, Fig. 93.78A-C; Ludwig (2007b): 237-238; Moser (2002): III/ Coprinus/3; Doveri (2004): 173-175; Breitenbach, Kränzlin (1995): Vol. 4, Fig. 295.

Localities: Bieszczady Mts, Bieszczady National Park, spruce coppice near the camping in Wetlina village; ATPOL: FG-68. One individual grew on horse dung; 06.10.2009; leg. \& det. B. Gierczyk; BGF/091006/0006.

Distribution AND REMARKs: Common and cosmopolitan species, known from many countries, growing on dung of herbivores (most common on horse, cattle and cow dung). Within the territory of Poland found only in nine localities (Wojewoda 2003; Adamczyk i in. 2004; Flisińska 2004).

Coprinopsis ochraceolanata (Bas) Redhead, Vilgalys \& Moncalvo (Coprinus ochraceolanatus Bas)

Fig. 20

DESCRIPTION AND ICONOGRAPHY: Uljé (2005): 59-60, Fig. 48; Ludwig (2007a): 79, Tabl. 265, Fig. 93.49; Ludwig (2007b): 201-202.

MACROSCOPIC AND MICROSCOPIC FEATURES: Basidiocarps medium-sized, pileus up to $60 \mathrm{~mm}$, first ovoid, then convex, often with lobed margin, striate, pale grey with darker apex. Veil appressed, fibrillose, forming a velar flocks and scales, ochraceous. Stipe 70-90 $\times$ 4-6 mm, whitish, fibrillose, with ochraceous veil remains at the base. Spores 9.0-13.0 $\times$ 5.5-8.0 $\mu \mathrm{m}$ (lit. 8.5-13.5 $\times$ 5.5-7.7 $\mu \mathrm{m}$ ), ellipsoid to ovoid, with rounded base and apex, central germ pore and dark red-brown color. Basidia 4-spored, 18-40 × 8-14 $\mu \mathrm{m}$ (lit. 15-38 × 8-11 $\mu \mathrm{m}$ ). Cheilocystidia subglobose, ellipsoid, ovoid to cylindrical, 40-100 × 20-45 $\mu \mathrm{m}$ (lit. 30-120 $\times 15-50 \mu \mathrm{m})$. Pleurocystidia elongate ellipsoid, subglobose, cylindrical to fusiform, 60-130 $\times 25-50 \mu \mathrm{m}$ (lit. 50$140 \times 20-50 \mu \mathrm{m})$. Veil composed of yellow to ochraceous, elongated, often fusiform

A
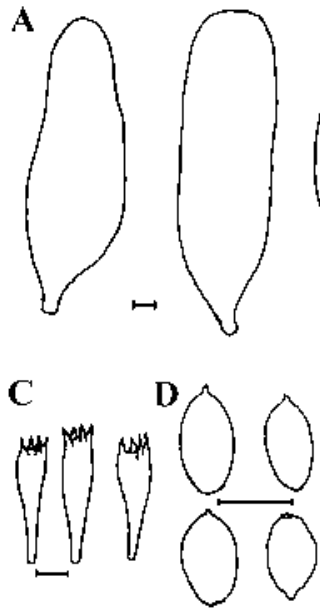
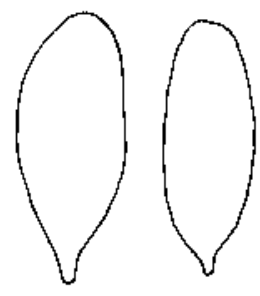

B

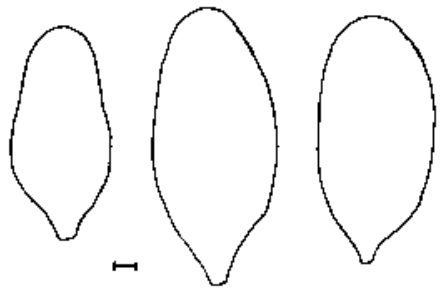

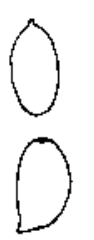

E

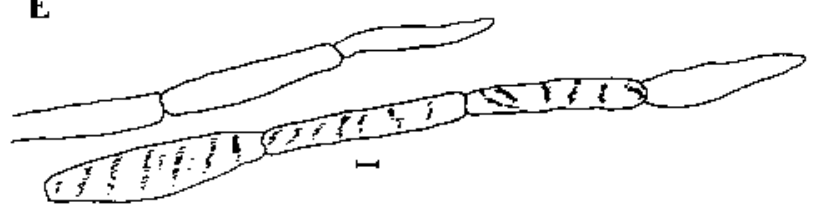

Fig. 20. Coprinopsis ochraceolanata microcharacters: A - pleurocystidia, B - cheilocystidia, $\mathrm{C}-$ spores, D - basidia, E - veil. Scale bars $=10 \mu \mathrm{m}$. 
hyphae with granular incrustation, 50-220 × 10-22 $\mu \mathrm{m}$, constricted at septa. Clampconnections present.

LocAlities: Poznań city, along Al. Wielkopolska street; ATPOL: BD-08. A dozen of basidiocarps were found on soil mixed with wood-chips under Aesculus hippocastanum trees; 22.05.2010; BGF/100522/0001.

Distribution, HABITAT AND REMARKs: Hitherto species known only from Netherlands, Great Britain and Germany, rare. It grows solitary on soil, wood-chips or near trunks. A species new to Poland, probably undercollected because of its similarity to C. lagopus - the color of the veil and its incrustation is clearly visible only on young basidiocarps.

Coprinopsis phaeospora (P. Karst.) P. Karst. (Coprinus phaeosporus P. Karst.) Fig. 21

Description AND ICONOGRAPHY: Uljé (2005): 80, Fig. 78; Ludwig (2007a): 92, Tabl. 278, Fig. 93.99A\&B; Ludwig (2007b): 260-262.

MACROSCOPIC AND MICROSCOPIC FEATURES: Basidiocarps medium sized, pileus up to $30 \mathrm{~mm}$, subglobose to conical, stipe $120 \times 0.5-2 \mathrm{~mm}$. Cap white with ochrebrown veil scales, stipe white to greyish. Spores 7.0-7.5 $\times$ 6.0-7.0 $\times$ 4.5-5.0 $\mu \mathrm{m}$ (lit.

A

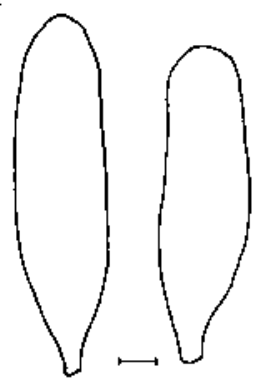

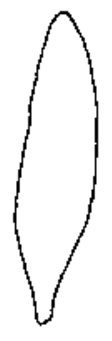
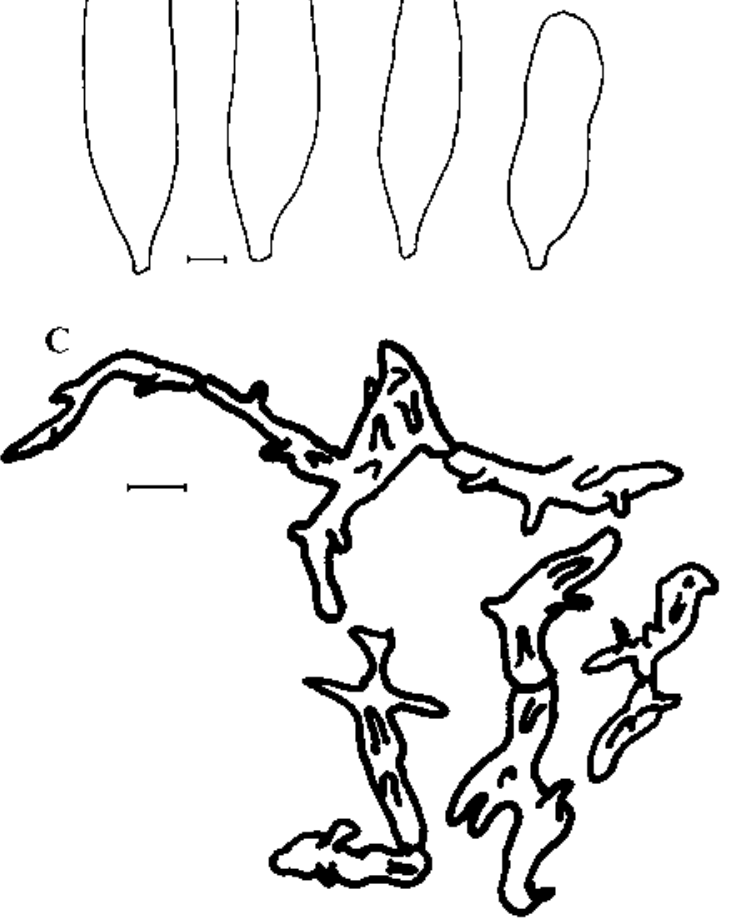

B

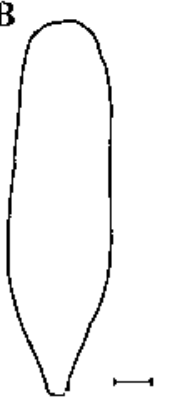

D
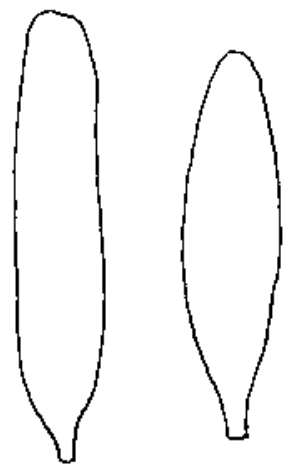
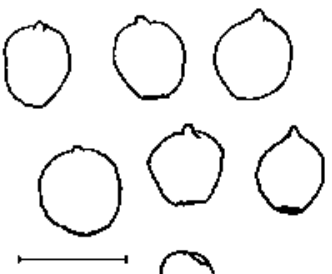

E
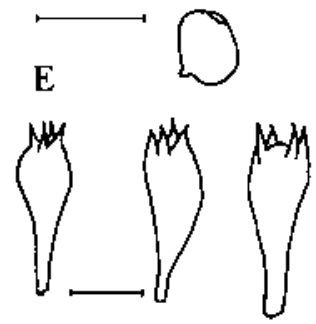

Fig. 21. Coprinopsis phaeospora microcharacters: A - cheilocystidia, B - pleurocystidia, $\mathrm{C}-$ veil, D - spores, E - basidia. Scale bars $=10 \mu \mathrm{m}$. 
5.5-8.0 $\times$ 4.5-7.0 $\times$ 4.5-6.0 $\mu \mathrm{m}$ ), distinctly flattened, subglobose to ovoid (some of maize-kernel shape), dark red-brown, with an eccentric germ pore. Basidia 4-spored, 18-25 × 8-9 $\mu \mathrm{m}$ (lit. 14-28 $\times$ 7-9 $\mu \mathrm{m}$ ). Cheilocystidia oblong to cylindrical 35-80 $\times 12-25 \mu \mathrm{m}$ (lit. 30-100 $\times 10-30 \mu \mathrm{m}$ ), pleurocystidia oblong, subcylindrical to subutriform, 55-90 $\times 15-22 \mu \mathrm{m}$ (lit. 50-100 $\times 10-30 \mu \mathrm{m}$ ). Veil consisting of thick-walled (walls up to $1.5 \mu \mathrm{m}$ wide), strongly diverticulate hyphae. Clampconnections present.

LOCALITIES: Poznań, eastern part of "Uroczysko Marcelin" forest, $250 \mathrm{~m}$ SW from Strzegomska street; ATPOL: BD-08. A dozen of individuals were found on grasses in Robinia pseudoacacia shrubs; 25.07.2009; leg., det. B. Gierczyk; BGF/090725/0001.

DISTRIBUTION, HABITAT AND REMARKS: Rarely reported but probably widespread ink-cap species, known from many European countries. It occurs solitary, on dead grasses and other herbs. Not mentioned in literature from Poland.

Coprinopsis pseudofriesii (Pilát \& Svrček) Redhead, Vilgalys \& Moncalvo (Coprinus pseudofriesii Pilát \& Svrček)

Fig. 22, Phot. 8

DesCription And iCONOGRAPHY: Uljé (2005): 80, Fig. 79; Ludwig (2007a): 92, Tabl. 278, Fig. 93.98A\&B; Ludwig (2007b): 259-260.

MACROSCOPIC AND MICROSCOPIC FEATURES: Basidiocarps medium sized, cap up to $20 \mathrm{~mm}$, conical, stipe $60 \times 1-2 \mathrm{~mm}$. Pileus whitish with ochre centre, stipe whitish. Veil forming ochre-brown patches, becoming paler with age. Spores 7.5-9.0 $\times$

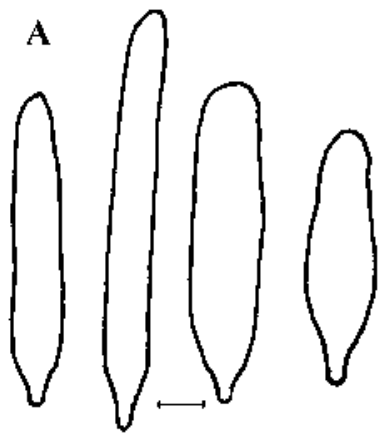

B
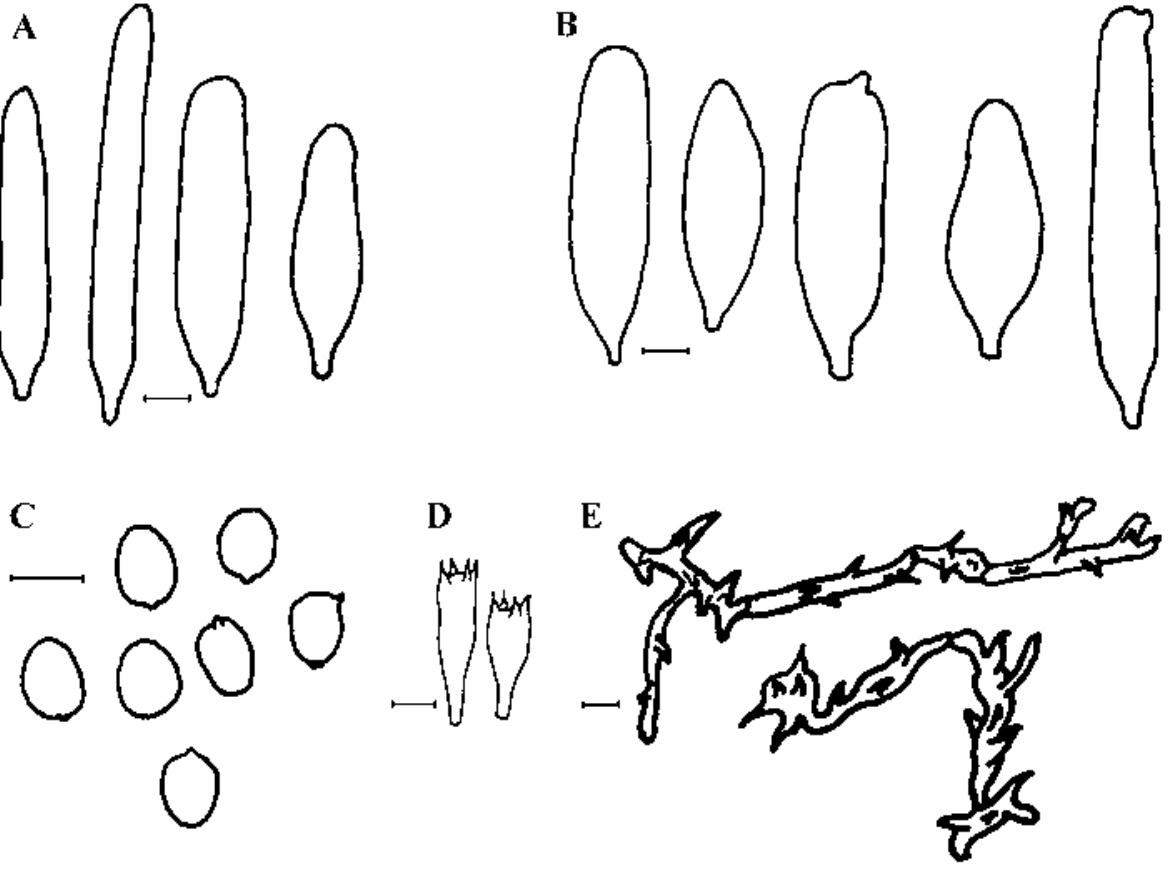

Fig. 22. Coprinopsis pseudofriesii microcharacters: A - cheilocystidia, B - pleurocystidia, $\mathrm{C}$ - spores, D - basidia, E - veil. Scale bars $=10 \mu \mathrm{m}$. 
5.5-7.0 $\mu \mathrm{m}$ (lit. 6.0-10.0 $\times$ 5.0-8.0 $\mu \mathrm{m}$ ), ellipsoid to slightly rhomboid, medium redbrown, with central germ pore. Basidia 4-spored, 18-25 × 8-10 $\mu$ m (lit. 18-32 $\times$ 9-11 $\mu \mathrm{m}$ ). Cheilocystidia cylindrical to narrowly utriform, 35-70 $\times 10-18 \mu \mathrm{m}$ (lit. $30-80 \times 7-22 \mu \mathrm{m})$, pleurocystidia similar, $60-80 \times 12-20 \mu \mathrm{m}($ lit. $60-120 \times 10-27 \mu \mathrm{m})$. Veil composed of diverticulate hyphae, 3-8 $\mu \mathrm{m}$ wide, with yellow walls up to $1.5 \mu \mathrm{m}$. Clamp-connections present.

LOCALITIES: Łozina near Wrocław; ATPOL: CE-30. A dozen of basidiocarps were found on old grasses stems, in the margin of a field; 17.06.2009, 01.07.2009; leg. T. Pachlewski, det. B. Gierczyk; BGF/090617/0001, BGF/090701/0001.

DistRIBUTION, HABITAT AND REMARKS: Widespread and rather common European species, known from, e.g., Sweden and Netherlands. It grows solitary on wood, dead grasses and herbs, sometimes on weathered dung of herbivores. A species new to Poland.

Coprinopsis pseudonivea (Bender \& Uljé) Redhead, Vilgalys \& Moncalvo (Coprinus pseudoniveus Bender \& Uljé)

Fig. 23

Description and iconography: Uljé (2005): 94, Fig. 101; Ludwig (2007a): 87, Tabl. 273, Fig. 93.79A\&B; Ludwig (2007b): 238-239; Doveri (2004): 181-184.

MACROSCOPIC AND MICROSCOPIC FEATURES: Basidiocarps medium-sized, pileus up to $45 \mathrm{~mm}$, first ovoid, then broadly conical to applanate, densely covered with mealy, cream veil (on young basidiocarps with rose tint). Stipe 50-80 $\times 3-4 \mathrm{~mm}$, whitish, with velar flocks. Spores 9.0-13.0 × 8.0-11.5 $\mu \mathrm{m}$ (lit. 9.0-12.5 × 7.5-11.5 $\mu \mathrm{m})$,

A
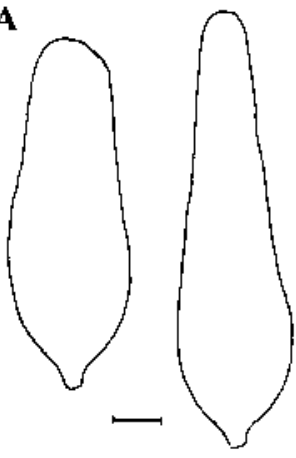

D

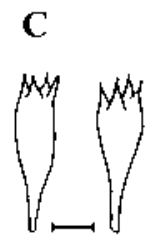

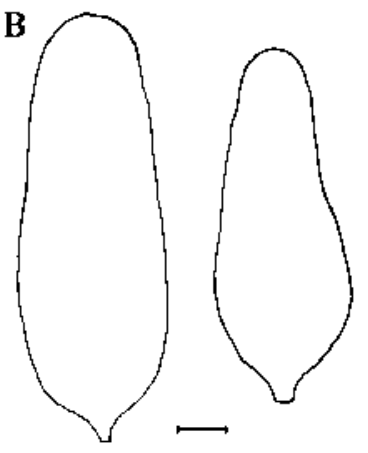

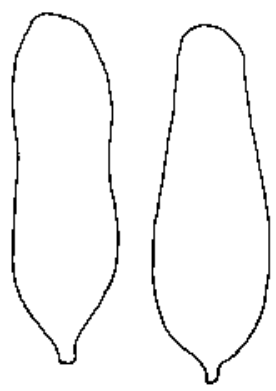

$\mathbf{E}$

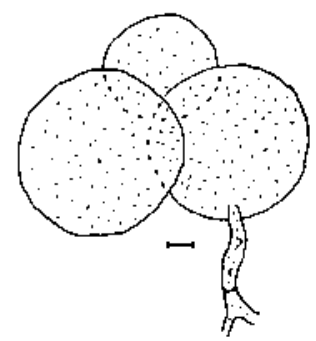

Fig. 23. Coprinopsis pseudonivea microcharacters: A - cheilocystidia, B - pleurocystidia, $\mathrm{C}$ - basidia, D - spores, E - veil. Scale bars $=10 \mu \mathrm{m}$. 
limoniform, with rounded base with apical papilla, central or slightly eccentric germ pore and dark red-brown color. Basidia 4-spored, 20-40 × 10-15 $\mu \mathrm{m}$ (lit. 15-40 $\times$ 9-13 $\mu \mathrm{m}$ ). Cheilocystidia utriform, ellipsoid to subcylindrical, 45-65 × 20-30 $\mu \mathrm{m}$ (lit. 40-65 × 20-27 $\mu \mathrm{m}$ ). Pleurocystidia utriform to subcylindrical, 80-150 × 30-55 $\mu \mathrm{m}$ (lit. $75-180 \times 25-50 \mu \mathrm{m})$. Veil composed of globose, up to $70 \mu \mathrm{m}$ wide elements, smooth or covered with indistinct granules dissolving in $\mathrm{HCl}$ and sparse, diverticulate, narrow hyphae. Clamp-connections very sparse.

LocAlities: Bieszczady National Park, horse stud in Wołosate village; ATPOL: FG-79. About ten fruitbodies were found on horse dung mixed with straw; 01.05.2010, 05.06.2010; leg. B. Gierczyk, A. Kujawa, det. B. Gierczyk; BGF/100601/0017, BGF/100605/0003.

Distribution, HABITAT AND REMARKS: Known only from Europe, rare, found in Netherlands, Germany, Great Britain, Denmark and Sweden. It grows on herbivores dung (most collections come from cow dung) or on dung mixed with straw and on compost heaps. Hitherto not mentioned from Poland.

Coprinopsis pseudoradiata (Watling) Redhead, Vilgalys \& Moncalvo (Coprinus pseudoradiatus Watling)

Fig. 24

DESCRIPTION AND ICONOGRAPHY: Uljé (2005): 61-62, Fig. 51; Orton, Watling (1979): 44-45, 126-127, Fig. 62; Doveri (2004): 155-157.

MACROSCOPIC AND MICROSCOPIC FEATURES: Basidiocarps small, pileus up to $12 \mathrm{~mm}$, first ellipsoid, then plane, striate, pale grey-drown with darker apex. Veil adpressed, fibrillose, forming a velar, recurved flocks, silvery grey. Stipe $20-45 \times 0.5-1 \mathrm{~mm}$, whitish, slightly fibrillose. Spores 8.0-9.5 × 5.0-5.8 $\mu \mathrm{m}$ (lit. 7.5-9.5 × 5.0-5.5 $\mu \mathrm{m})$, ellipsoid, with rounded base and apex, central germ pore and dark red-brown to black color. Basidia 4-spored, 20-30 × 8-10 $\mu \mathrm{m}$ (lit. 18-32 × 8-10 $\mu \mathrm{m}$ ). Cystidia not seen (according to literature cheilocystidia subglobose, ellipsoid, ovoid to oblong or utriform, 25-40 × 15-28 $\mu \mathrm{m}$; pleurocystidia ellipsoid, oblong, utriform to subcylindrical,
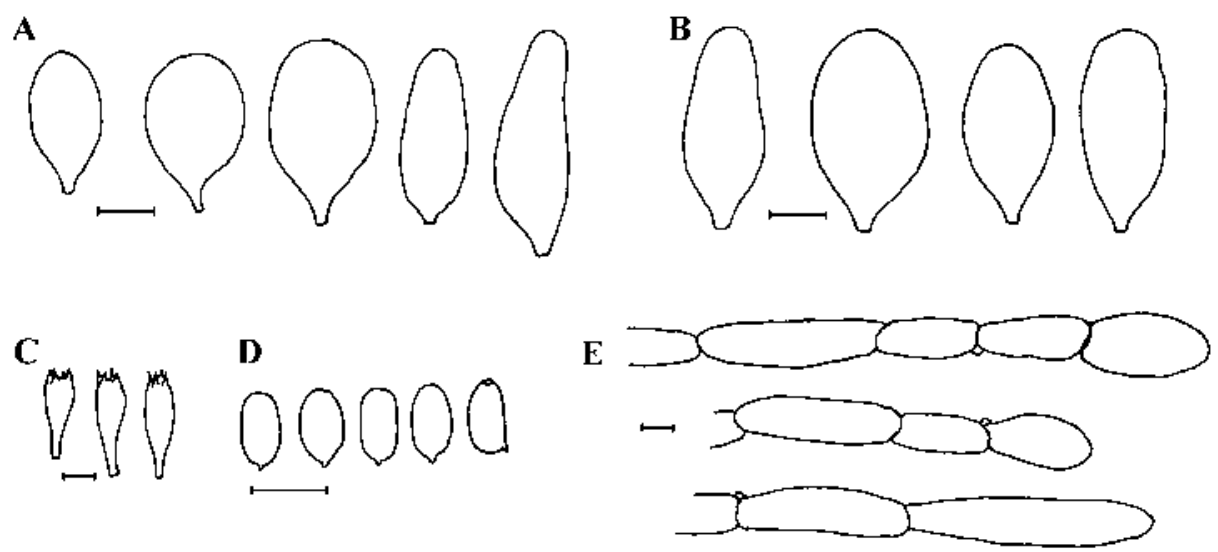

Fig. 24. Coprinopsis pseudoradiata microcharacters: A - cheilocystidia, B - pleurocystidia, C - spores, D - basidia, E - veil. Cheilo- and pleurocystidia presented according to Uljé (2003) and Orton \& Watling (1979). Scale bars $=10 \mu \mathrm{m}$. 
30-80 $\times 20-30 \mu \mathrm{m})$. Veil composed of hyaline, elongated hyphae, 40-200 $\times 10-25$ $\mu \mathrm{m}$, constricted at septa, with subglobose terminal elements. Clamp-connections present.

Localities: Bieszczady National Park, horse stud in Wołosate village; ATPOL: FG-79. A few fruitbodies were found on horse dung mixed with straw; 01.05.2010; leg., det. B. Gierczyk; BGF/100601/0014.

DisTRIBUTION, HABITAT AND REMARKS: Widespread but rather rare European species. It grows in small groups on herbivores dung or straw mixed with dung. Hitherto not mentioned from Poland.

Coprinopsis radiata (Bolton) Redhead, Vilgalys \& Moncalvo (Coprinus radiatus (Bolton) Fr.)

DesCRIPTION AND ICONOGRAPHY: Uljé (2005): 67, Fig. 59; Orton, Watling (1979): 43-44, 126-127, Fig. 65, 67, 75; Ludwig (2007a): 81, Tabl. 267, Fig. 93.56; Ludwig (2007b): 210-211; Doveri (2004): 157-160; Breitenbach, Kränzlin (1995): Vol. 4, Fig. 299.

Localities: 1. Kaczawskie Mountains, "Góra Miłek" reserve near Wojcieszów village, ATPOL: BE-61. On horse dung in beech forest belonging to the Cephalanthero-Fagenion alliance. A dozen of basidiocarps were found; 03.10.2008; leg., det. B. Gierczyk; BGF081003/0009. 2. Bieszczady Mts, Bieszczady National Park, spruce coppice near the camping in Wetlina village; ATPOL: FG-68. A dozen of individuals grew on horse dung; 23.06.2009; leg. T. Pachlewski, B. Gierczyk, det. B. Gierczyk; BGF/090623/0002. 3. Bieszczady National Park, horse stud in Wołosate village; ATPOL: FG-79. A dozen of basidiocarps on the straw mixed with horse dung; 01.06.2010, 05.06.2010; leg., det. B. Gierczyk; BGF/100601/0011, BGF/100605/0010.

Distribution AND REMARKs: Species rare but widespread in Europe. Known from, e.g., Great Britain, Italy, Scandinavian Countries and Netherlands, growing on heaps or mixed or pure dung of herbivores (especially horses). In Poland, mentioned from eight localities (Wojewoda 2003), probably overlooked.

Coprinopsis romagnesiana (Singer) Redhead, Vilgalys \& Moncalvo (Coprinus romagnesianus Singer)

Fig. 25, Phot. 9

Description And iconography: Uljé (2005): 58, Fig. 45; Orton, Watling (1979): 55, 122-123, Fig. 41, 43; Ludwig (2007b): 147-148 (as C. atramentarius v. romagnesianus); Moser (2002): III/Coprinus/2.

MACROSCOPIC AND MICROSCOPIC FEATURES: Basidiocarps large, pileus up to $90 \mathrm{~mm}$, first ellipsoid to ovoid, then campanulate to flat, greyish to pale brown, cowered with brown, rusty to apricot squamules. Stipe $60-100 \times 5-13 \mathrm{~mm}$, white, covered with dark squamules, with clavate, somewhat marginate base. Spores 8.0-10.0 $\times 4.5$ $6.0 \mu \mathrm{m}$ (lit. 8.0-11.5 $\times$ 4.5-6.5 $\mu \mathrm{m}$ ), ellipsoid to ovoid, with central germ pore and rounded base and apex, dark red-brown. Basidia 4-spored, 20-30 × 7-10 $\mu \mathrm{m}(18-32$ $\times 7-10 \mu \mathrm{m}$ ). Cheilocystidia narrowly cylindrical to utriform, 70-100 $\times 20-25 \mu \mathrm{m}$ (lit. 50-100 $\times 15-30 \mu \mathrm{m}$ ), pleurocystidia cylindrical to slightly utriform, 120-150 $\times 18-35$ $\mu \mathrm{m}$ (lit. 100-170 $\times 20-40 \mu \mathrm{m}$ ). Veil composed of branched to slightly diverticulate hyphae, thick-walled at places. Fasciculate, on or near stumps.

Localities: 1. Puszcza Knyszyńska Forest, about $6 \mathrm{~km}$ NE from Surpaśl village; ATPOL: GC-02. A few individuals grew on the birch trunk in mixed forest; 26.09.2009; leg. M. Gryc, det. B. Gierczyk; BGF/BF/090926. 2. Białowieża Primeval 


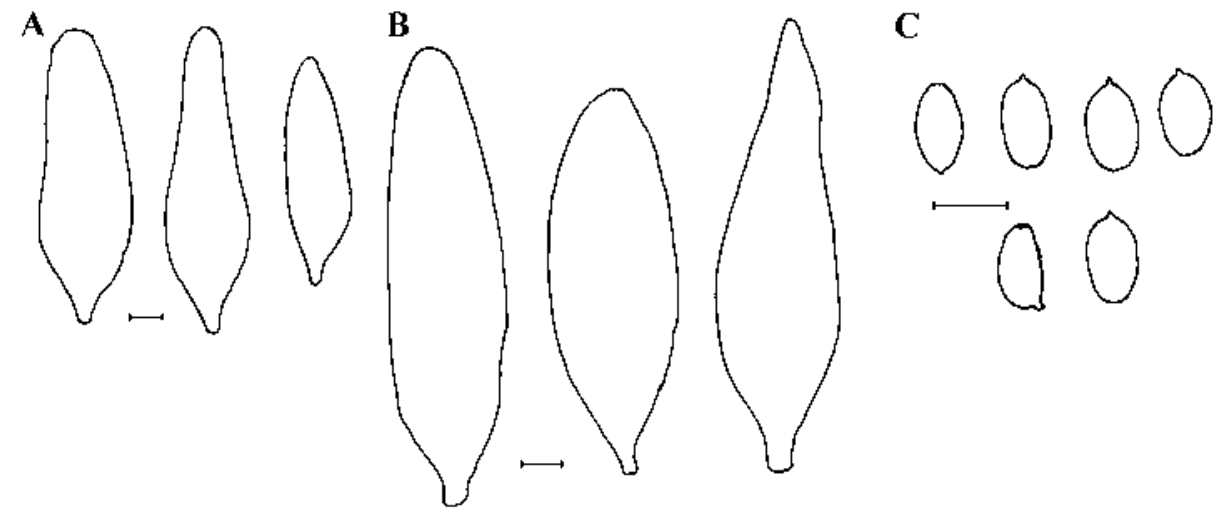

D

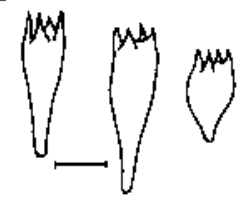

$\mathbf{E}$

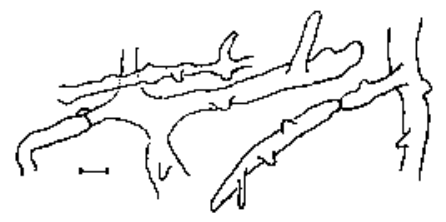

Fig. 25. Coprinopsis romagnesiana microcharacters: A - cheilocystidia, B - pleurocystidia, $\mathrm{C}$ - spores, D - basidia, E - veil. Scale bars $=10 \mu \mathrm{m}$.

Forest, compartment no. 524; ATPOL: GC-65. Fascicule consisting of ten basidiocarps were found on the ground near the stump of deciduous tree; 18.09.2009; leg. anonymous, det. B. Gierczyk; BGF/090918/0003.

Distribution, habitat and Remarks: Species known from North America and Europe. Rather rare, but widespread, known from Scandinavian Countries, Netherlands and Great Britain. It grows fasciculary, on or near stumps. A species new to Poland.

Coprinopsis spelaiophila (Bas \& Uljé) Redhead, Vilgalys \& Moncalvo (Coprinus spelaiophilus Bas \& Uljé)

Description AND ICONOGRAPHY: Uljé (2005): 69, Fig. 62; Ludwig (2007a): 79, Tabl. 265, Fig. 93.48A\&B; Ludwig (2007b): 200-201.

Localities: 1. Dezydery Chłapowski Landscape Park, Turew, palace park, ATPOL: DB-48. Two basidiocarps were found in a hollow trunk of deciduous tree; 31.05.2009; leg. T. Pachlewski, det. B. Gierczyk; ZBŚRiL 1/31.05.09. 2. Bieszczady Mts, Bieszczady National Park, along the path between Górna Solinka valley and Gen. Gładysz tomb; ATPOL: FG-68. Four basidiocarps grew in wound in the trunk of living Acer pseudoplatanus; 02.06.2010; leg. T. Pachlewski, det. B. Gierczyk; BGF/100602/0002.

Distribution AND REMARKs: The species rare in Europe, known from Netherlands, England, France, Germany, Spain, Italy, Turkey, Denmark, Finland and Sweden, growing on wood, often it wounds of living deciduous trees. Mentioned from six localities in Poland (Wojewoda 2003, as Coprinus extinctorius (Bull.) Fr.). 
Coprinopsis stangliana (Enderle, Bender \& Gröger) Redhead, Vilgalys \& Moncalvo (Coprinus stanglianus Enderle, Bender \& Gröger)

Fig. 26

Description And iconography: Uljé (2005): 71-72, Fig. 65; Ludwig (2007a): 88, Tabl. 274, Fig. 93.85; Ludwig (2007b): 245-246; Moser (2002): III/ Coprinus/18.

MACROSCOPIC AND MICROSCOPIC FEATURES: Basidiocarps large, cap up to $60 \mathrm{~mm}$, first ellipsoid to ovoid, then convex, pale greyish, cream-colored to ochre-brown, stipe $120 \times 3-10 \mathrm{~mm}$. Veil form grey to ochre-brown patches on pileus, especially in the centre. Spores 9.5-11.5 × 7.0-9.0 $\mu \mathrm{m}$ (lit. 8.5-12.0 $\times$ 6.0-9.0 $\mu \mathrm{m}$ ), ellipsoid to ovoid, very dark brown to black, with central germ pore, rounded base and rounded to slightly acute apex. Basidia 4-spored, 25-40 × 10-12 $\mu \mathrm{m}$ (lit. 18-47 × 8-13 $\mu \mathrm{m}$ ). Lamellar cystidia not seen (lit.: cheilocystidia utriform, oblong to broadly conical, 50-135 $\times 18-45 \mu \mathrm{m}$; pleurocystidia ellipsoid, oblong to cylindrical, 75-165 $\times 21-50$ $\mu \mathrm{m})$. Veil composed of diverticulate, thin-walled hyphae up to $10 \mu \mathrm{m}$ thick. Clampconnections present.

LocalitiEs: Miechowska Basin, on the S slope of the hill in Fęfłówka, near Miechów. One basidiocarp was found in xerothermic, limestone grassland belong-

A
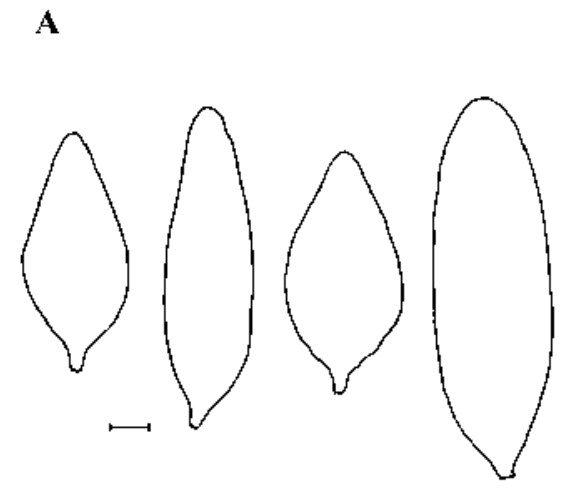

C

D

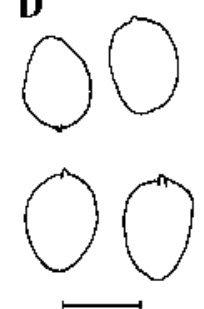

B

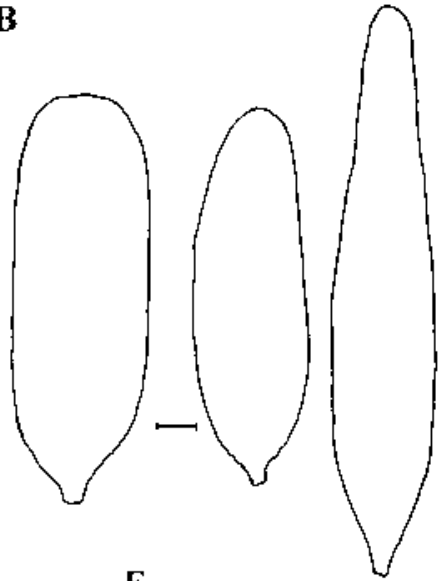

E
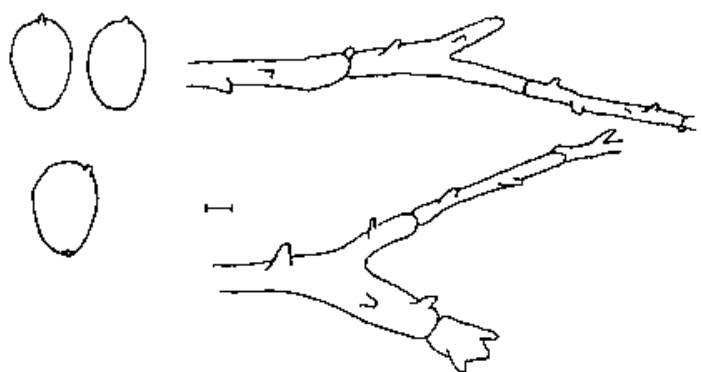

Fig. 26. Coprinopsis stangliana microcharacters: A - cheilocystidia, B - pleurocystidia, C - spores, D - basidia, E - veil. Cheilo- and pleurocystidia presented according to Uljé (2003). Scale bars $=10 \mu \mathrm{m}$ 
ing to the Inuletum ensifoliae association, on calciferous soil; 17.07.2009; leg., det. B. Gierczyk; BGF/090717/0001.

DistRIBUTION, HABITAT AND REMARKS: Very rare ink-cap species known only from Europe (Finland, Netherlands, Germany, Belgium, Italy, Great Britain), occurring solitary in dry limestone grasslands. A species new to Poland.

Coprinopsis tigrinella (Boud.) Redhead, Vilgalys \& Moncalvo (Coprinus tigrinellus Boud.)

Fig. 27

DESCRIPTION AND ICONOGRAPHY: Uljé (2005): 81, Fig. 80; Orton, Watling (1979): 48-49, Breitenbach, Kränzlin (1995): Vol. 4, Fig. 304.

MACROSCOPIC AND MICROSCOPIC FEATURES: Basidiocarps small, pileus up to $14 \mathrm{~mm}$, ovoid to ellipsoid, then broadly conical, white with dark centre (brown or sepia). Stipe up to $60 \times 2 \mathrm{~mm}$, white to greyish. Veil on cap forming brown, paler with age,

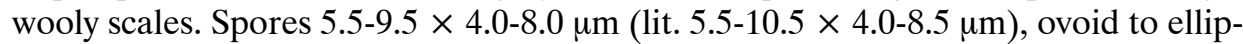
soid, with central or slightly eccentric germ pore, rounded apex and base, red-brown. Basidia 4-spored, 15-30 × 8-11 $\mu \mathrm{m}$ (lit. 12-28 × 8-10 $\mu \mathrm{m})$. Cheilocystidia subglobose, ellipsoid, utriform to conical, 45-100 $\times$ 20-30 $\mu \mathrm{m}$ (lit. 40-100 $\times 18-32 \mu \mathrm{m}$ ). Pleurocystidia similar, with tapering apex, 55-110 × 20-30 $\mu \mathrm{m}$ (lit. 50-120 × 16-28 $\mu \mathrm{m})$. Veil composed of thick-walled, diverticulate hyphae, up to $10 \mu \mathrm{m}$ wide, with walls up to $1.5 \mu \mathrm{m}$ thick. Clamps present.

Localities: Bieszczady Mts, Bieszczady National Park, Wołosate, herbaceous shrubs along Wołosatka stream; ATPOL: GG-70. One basidiocarp was found on dead grass stem; 09.07.2008; leg. T. Pachlewski, det. A. Kujawa, B. Gierczyk; ZBŚRiL 10/BdPN/090708 (locality mentioned by Gierczyk et al. 2009).

Distribution, HABITAT AND REMARKS: Rather rare species, widespread in Europe (e.g., Netherlands, Great Britain), known also from South America, occurring solitary on dead grass stems. In Poland, know only from Bieszczady Mts (Gierczyk et al. 2009).

A

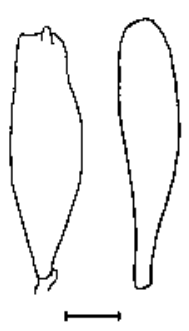

D

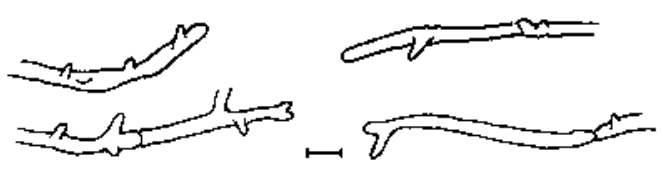

$\mathrm{B}$
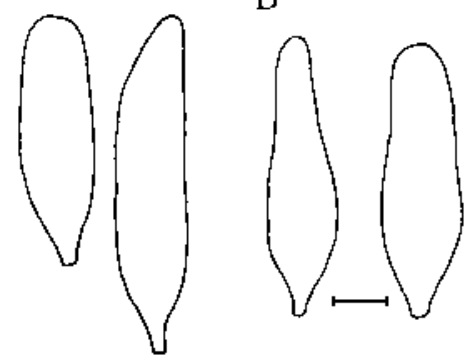

$\mathrm{F}$

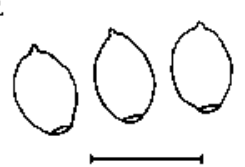

C.
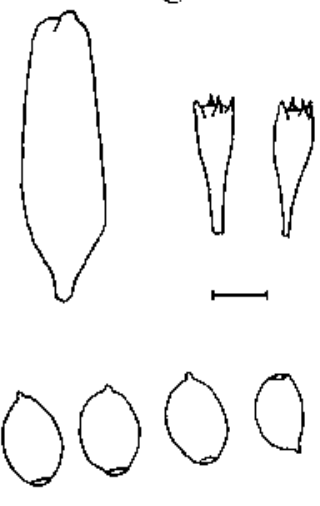

Fig. 27. Coprinopsis tigrinella microcharacters: A - cheilocystidia, B - pleurocystidia, C - basidia, D - veil, E - spores. Scale bars $=10 \mu \mathrm{m}$. 
Coprinopsis trispora (Kemp \& Watling) Redhead, Vilgalys \& Moncalvo (Coprinus trisporus Kemp \& Watling)

Fig. 28

DESCRIPTION AND ICONOGRAPHY: Uljé (2005): 104-105, Fig. 118; Orton, Watling (1979): 75-76, 136-137, Fig. 141, 148, 152; Ludwig (2007a): 84, Tabl. 270, Fig. 93.66A\&B; Ludwig (2007b): 222-223.

MACROSCOPIC AND MICROSCOPIC FEATURES: Basidiocarps small, cap up to $25 \mathrm{~mm}$, at first subglobose to oblong, then campanulate, stipe up to $50 \times 1-3 \mathrm{~mm}$. Pileus covered with hairy floccose veil, white to mouse grey. Smell distinct, narcotic. Spores 7.0-9.0 × 4.5-5.0 $\mu \mathrm{m}$ (lit. 6.5-9.0 × 4.5-5.5 um). Basidia 3-spored, 15-18 × 7-8 $\mu \mathrm{m}$ (lit. 10-24 $\times 6-9 \mu \mathrm{m})$. Cheilocystidia subglobose to subcylindrical and utriform, 35-60 $\times$ 20-40 $\mu \mathrm{m}$ (lit. 30-70 $\times 15-45 \mu \mathrm{m}$ ), pleurocystidia utriform to subcylindrical, 70-100 $\times 20-25 \mu \mathrm{m}$ (lit. 50-100 $\times 22-50 \mu \mathrm{m}$ ). Veil composed from globose, warty cells, 30-60 $\mu \mathrm{m}$ wide (lit. up to $75 \mu \mathrm{m}$ ), connected with narrow, diverticulate hyphae. Clampconnections absent.

Localities: Bieszczady Mts, Bieszczady National Park, spruce coppice near the camping in Wetlina village; ATPOL: FG-68. Three individuals were found on horse dung; 23.06.2009; leg. T. Pachlewski, B. Gierczyk, det. B. Gierczyk; BGF/090623/0003.

DisTRIBUTION, HABITAT AND REMARKs: Very rare species, known from Netherlands, Scandinavian countries and Great Britain, occurring solitary to subfasciculate on horse or cow dung. Hitherto not mentioned from Poland.

Coprinopsis tuberosa (Quél.) Doveri, Granito \& Lunghini (Coprinus tuberosus Quél.)

DesCRIPTION AND ICONOGRAPHY: Uljé (2005): 103-104, Fig. 117; Orton, Watling (1979): 77-78, 136-137, Fig. 142, 147; Ludwig (2007a): 83, Tabl. 269, Fig. 93.61A\&B; Ludwig (2007b): 216-218; Doveri (2004): 166-170.

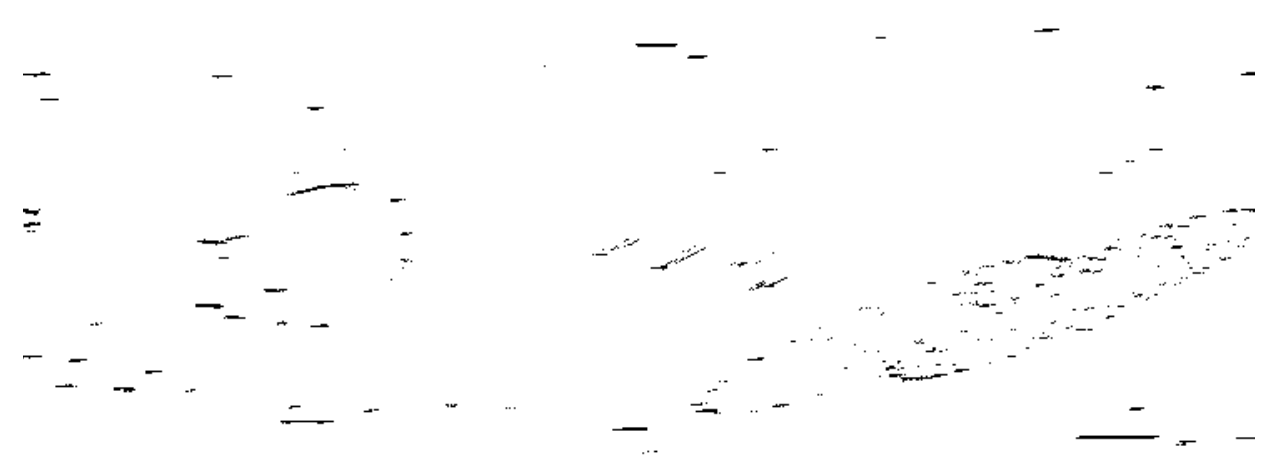

Fig. 28. Coprinopsis trispora microcharacters: A - cheilocystidia, B - pleurocystidia, C - spores, $\mathrm{D}$ - basidia, E - veil. Scale bars $=10 \mu \mathrm{m}$. 
Localities: 1. Bieszczady Mts, Bieszczady National Park, spruce coppice near the camping in Wetlina village; ATPOL: FG-68. Four individuals were found on horse dung;23.06.2009; leg. T. Pachlewski \& B. Gierczyk, det. B. Gierczyk; BGF/090623/0004. 2. Bieszczady National Park, horse stud in Wołosate village, ATPOL: FG-79. One basidiocarp was found on horse dung mixed with straw; 24.08.2009; leg., det. B. Gierczyk; BGF/090824/0002.

DisTRIBUTION AND REMARKS: Widespread and rather common ink-cap species. Known from many European countries, growing on mixed dung and compost heaps. Reported only twice from Poland: from Kuźnica Białostocka and Białowieża National Park (Chmiel, Sadowska 1994; Wojewoda 2003).

Coprinopsis urticicola (Berk. \& Broome) Redhead, Vilgalys \& Moncalvo v. urticicola (Coprinus urticicola (Berk. \& Broome) Buller v. urticicola)

Fig. 29, Phot. 10

DesCription AND ICONOGRAPHY: Uljé (2005): 77, Fig. 73; Orton, Watling (1979): 47-48, 128-129, Fig. 78; Ludwig (2007a): 91, Tabl. 277, Fig. 93.95; Ludwig (2007b): 255-257; Moser (2002): III/Coprinus/11; Breitenbach, Kränzlin (1995): Vol. 4, Fig. 306.

MACROSCOPIC AND MICROSCOPIC FEATURES: Basidiocarps small, pileus up to $13 \mathrm{~mm}$, at first subglobose to ovoid, then conical, white. Stipe up to $30 \times 1 \mathrm{~mm}$, white to greyish. Veil on cap pure white, forming wooly scales. Spores 6.0-9.0 $\times 5.0-6.5 \mu \mathrm{m}$ (lit. 5.5-9.0 $\times$ 4.5-6.5 $\mu \mathrm{m}$ ), pale red-brown, broadly ellipsoid with conical base and rounded apex, germ pore central. Basidia 4-spored, 10-22 × 6-10 um (lit. 10-23 × 6-9 $\mu \mathrm{m})$. Cheilocystidia and pleurocystidia cylindrical, utriform to conical, the former 35-60 × 10-12 um (lit. 30-65 × 10-14 um), the latter 45-70 × 11-15 um (lit. 40-70 × 10-15 $\mu \mathrm{m})$. Veil-forming hyphae diverticulate, up to $8-9 \mu \mathrm{m}$ wide, with slightly encrusted walls. Clamps absent.

A

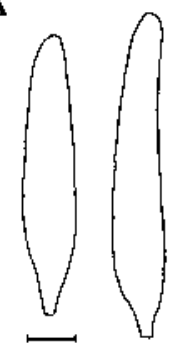

C

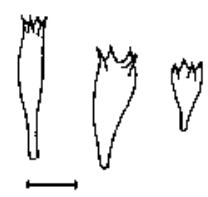

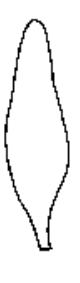

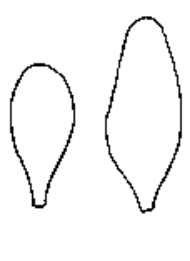

D

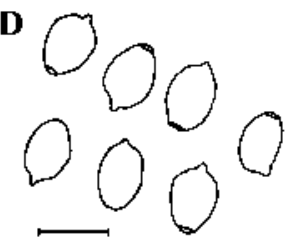

B
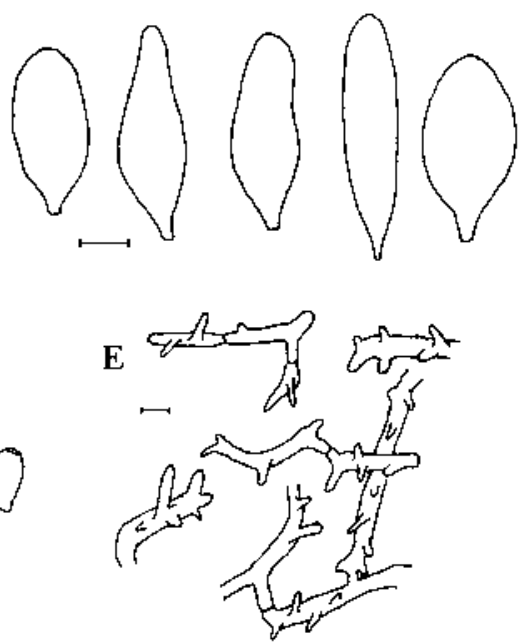

Fig. 29. Coprinopsis urticicola v. urticicola microcharacters: A - cheilocystidia, B - pleurocystidia, C - spores, D - basidia, E - veil. Scale bars $=10 \mu \mathrm{m}$. 
Localities: 1. Bieszczady Mts, Bieszczady National Park, Wołosate, along the road to Beskid pass; ATPOL: GG-70. A few basidiocarps were found on dead Rumex alpinus stems on the road-side; 07.07.2008; leg. P. Chachuła, det. A. Kujawa; ZBŚRiL 32/BdPN/070708 (locality mentioned by Gierczyk et al. 2009). 2. Bieszczady Mts, Bieszczady National Park, Wołosate, along the red tourist trail to Bukowska pass, "Wyżny Koniec" slope; ATPOL: GG-70. A few basidiocarps were found on dead Rumex alpinus stems on the road-side; 08.07.2008; leg. P. Chachuła, det. A. Kujawa; ZBŚRiL 16/BdPN/080708 (locality mentioned by Gierczyk et al. 2009).

Distribution, HABITAT AND REMARKs: Common and widespread species, known from Europe (e.g., Netherlands, Great Britain) and North America. In Poland, found only in Bieszczady Mts (Gierczyk et al. 2009). It occurs solitary on dead grasses and herbs, very rarely on wood.

Coprinopsis xenobia (P.D. Orton) Redhead, Vilgalys \& Moncalvo (Coprinus xenobius P.D. Orton)

Fig. 30

Description AND ICONOGRAPHY: Uljé (2005): 70-71, Fig. 64; Orton, Watling (1979): 52-53, 128-128, Fig. 87; Ludwig (2007a): 92, Tabl. 278, Fig. 93.97; Ludwig (2007b): 258-259; Doveri (2004): 144-146; Moser (2002): III/Coprinus/12.

MACROSCOPIC AND MICROSCOPIC FEATURES: Basidiocarps small, pileus up to $8(20)$ $\mathrm{mm}$, first subglobose to ellipsoid, then expanded, stipe $40 \times 0.3-2 \mathrm{~mm}$. Cap white with grey-cream centre, veil whitish, hairy-floccose, stipe white to whitish. Spores 11.0-12.5 $\times$ 6.5-7.0 $\mu \mathrm{m}$ (lit. 9.5-14.5 $\times$ 5.0-8.0 $\mu \mathrm{m}$ ), oblong to ellipsoid, dark redbrown, with rounded base and central germ pore. Basidia 4-spored, 20-25 $\times 8-9 \mu \mathrm{m}$

A
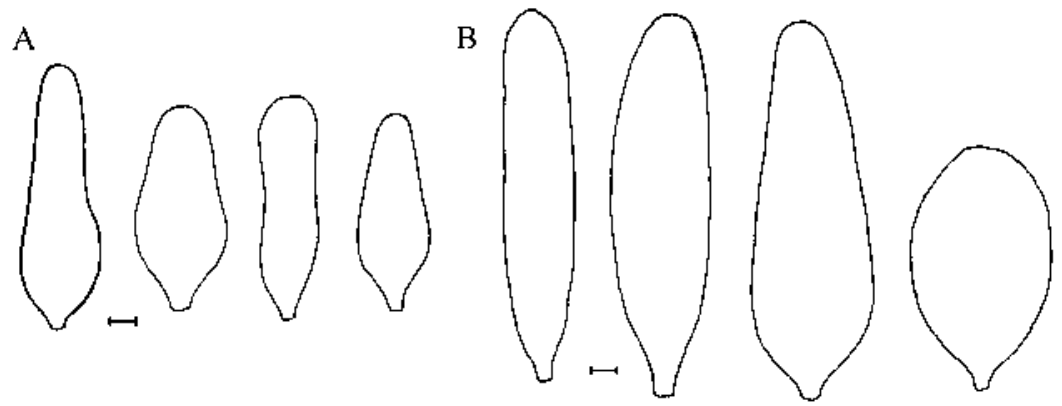

D

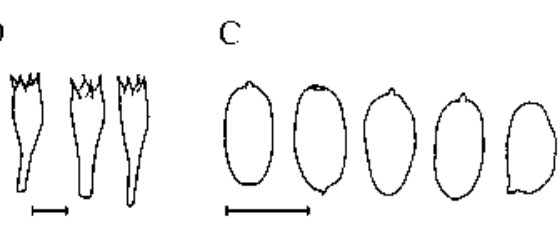

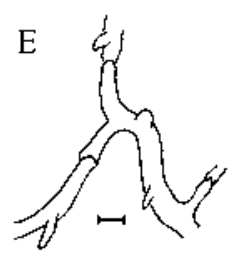

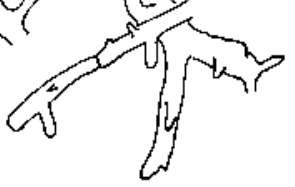

Fig. 30. Coprinopsis xenobia microcharacters: A - cheilocystidia, B - pleurocystidia, C - basidia, D - spores, E - veil. Scale bars $=10 \mu \mathrm{m}$. 
(lit. 18-32 × 8-10 $\mu \mathrm{m}$ ). Cheilocystidia utriform, rarely globose to cylindrical, $60-90 \times$ 25-35 $\mu \mathrm{m}$ (lit. 60-100 $\times$ 22-40 $\mu \mathrm{m}$ ). Pleurocystidia cylindrical to ellipsoid, $95-110 \times$ 25-40 $\mu \mathrm{m}$ (lit. 90-125 $\times$ 20-40 $\mu \mathrm{m}$ ). Veil hyphae diverticulate, thin-walled, up to 10 $\mu \mathrm{m}$ width. Clamp-connections present.

LocAlities: Bieszczady National Park, horse stud in Tarnawa village; ATPOL: GG-60. A few basidiocarps were found on horse dung mixed with straw; 24.06.2009; leg., det. B. Gierczyk; BGF/090624/0002.

DistriBUTION, HABITAT AND REMARKs: Rare species, known only from a few records in Europe (Great Britain, Italy, Germany, Netherlands, Finland and Norway), growing solitary (rarely subfasciculate) on dung of herbivores (cow, elk, cattle). A species new to Poland.

\section{Coprinus Pers.}

Coprinus sterquilinus (Fr.) Fr., E

DesCRIPTION AND ICONOGRAPHY: Uljé (2005): 109, Fig. 125; Orton, Watling (1979): 30-31, 122-123, Fig. 38, 44; Ludwig (2007a): 69, Tabl. 255, Fig. 93.3; Ludwig (2007b): 150-151; Doveri (2004): 136-139.

LocAlities: Bieszczady National Park, horse stud in Wołosate village, ATPOL: FG-79. A few fruitbodies were found on horse dung mixed with straw in stable; 24.08.2009; leg., det. B. Gierczyk; BGF/090824/0001.

Distribution AND REMARKs: Widespread but rare species, found in Europe (e.g., in Scandinavian countries, Netherlands, Great Britain, Italy), Asia and North America, growing on dung or dung mixed with straw or vegetable refuse (preferably on horse dung). Hitherto in Poland found only once, in Botanical Garden in Kraków (Wojewoda 1996).

\section{Parasola Redhead, Vilgalys \& Hopple.}

Parasola auricoma (Pat.) Redhead, Vilgalys \& Hopple (Coprinus auricomus Pat.)

Description And iconography: Uljé (2005): 34, Fig. 1; Orton, Watling (1979): 98-99, 146-147, Fig. 230, 231; Ludwig (2007a): 73, Tabl. 259, Fig. 93.19A,B; Ludwig (2007b): 167-168; Moser (2002): III/ Coprinus/25; Breitenbach, Kränzlin (1995): Vol. 4, Fig. 266.

LocAlities: 1. 2 km S from Lusowo village near Poznań; ATPOL: BD-07. A dozen of basidiocarps were found on forest path, under Populus tremula, Corylus avellana and Fraxinus excelsior, among mosses; 06.09.2009; leg., det. B. Gierczyk; BGF/090906/0001. 2. Poznań, western part of "Uroczysko Marcelin" forest, along black bicycle route near Junikowski stream; ATPOL: BD-08. Two fruitbodies were found on moist soil under Alnus glutinosa; 06.06.2009, 08.05.2010, 15.05.2010; leg., det. B. Gierczyk; BGF/090606/0002, BGF/100508/0001 \& BGF/100515/0001. 3. 2 km S from Będlewo village near Mosina; ATPOL: BD-27. A few basidiocarps were found in ashforest, on moist soil; 13.05.2009; leg., det. B. Gierczyk; BGF/090513/0001. 4. Szałe near Kalisz, allotments; ATPOL: CD-87. A dozen of basidiocarps were found on lawn; 00.06.2009; leg. N. Kolasińska, det. B. Gierczyk; BGF/090600/0001. 5. Manorial park around the Habsburgs Palace in Żywiec village; ATPOL: DG-04. A few basidiocarps on the wood chips; 15.05.2010, 29.05.2010; leg. R. Taran, det. B. Gierczyk; BGF/BF/100515/0001, BGF/BF/100529/0003, BGF/BF/100529/0004, BGF/BF/100529/0005. 
Distribution AND REMARKs: Widespread and very common species, known from Europe and Japan, growing on soil and wood-chips on paths and grasslands, along roads and in lawns. Reported only in seven localities in Poland (Wojewoda 2003; Kujawa 2009). Probably misidentified as other Parasola species (mainly Parasola plicatilis (Curtis) Redhead, Vilgalys \& Hopple).

Parasola galericuliformis (Watling) Redhead, Vilgalys \& Hopple (Coprinus galericuliformis Watling)

Fig. 31

Description And iconography: Uljé (2005): 36, Fig. 4; Orton, Watling (1979): 102, 146-147, Fig. 223a\&b, 227; Ludwig (2007a): 73, Tabl. 259, Fig. 93.16; Ludwig (2007b): 165.

MACROSCOPIC AND MICROSCOPIC FEATURES: Basidiocarps medium-sized, cap up to 10-30 mm, first ellipsoid to ovoid, then convex to flattened, stipe up to $70 \times 1-3 \mathrm{~mm}$. Pileus sulcate-striate, dark grey to rusty, becoming paler with age, stipe whitish to pale brownish. Spores 9.5-11.0 × 9.0-9.5 × 6.5-7.5 $\mu \mathrm{m}($ lit. 8.0-11.0 $\times$ 7.5-9.5 × 7.0$7.5 \mu \mathrm{m}$ ), (sub)globose, sometimes slightly 5 -angular, flattened, dark red-brown with rounded base and slightly eccentric germ pore. Basidia 4-spored, 18-30 $\times 10-11 \mu \mathrm{m}$ (lit. 20-40 $\times 10-13 \mu \mathrm{m}$ ). Cheilocystidia lageniform to cylindrical, $25-45 \times 11-20 \mu \mathrm{m}$ (lit. 25-60 $\times 10-23 \mu \mathrm{m}$ ), pleurocystidia lageniform to utriform, $65-90 \times 20-25 \mu \mathrm{m}$ (lit. $60-95 \times 18-30 \mu \mathrm{m})$. Veil absent, clamp-connections present.

Localities: Bieszczady National Park, Górny San valley, historical cemetery in non-existing village Dźwiniacz Górny; ATPOL: GG-60. Two basidiocarps were found on bare, moist soil, under Ulmus sp.; 24.06.2009; leg., det. B. Gierczyk; BGF/090624/0001.

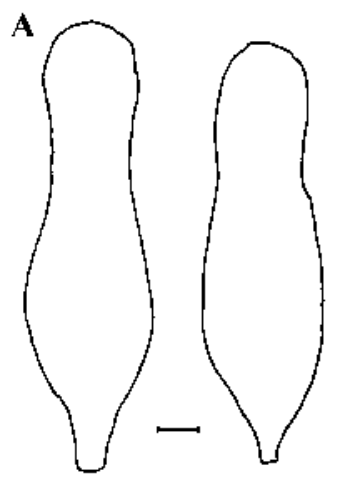

C

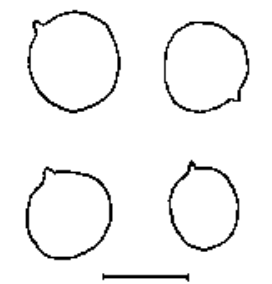

B

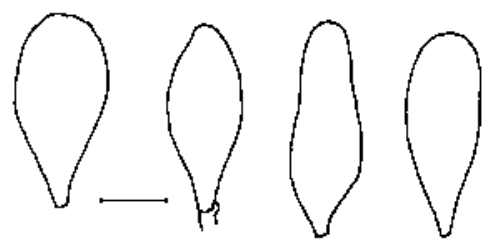

D

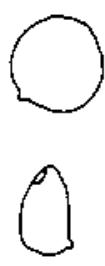

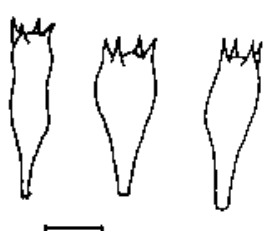

Fig. 31. Parasola galericuliformis microcharacters: A - pleurocystidia, B - cheilocystidia, $\mathrm{C}-$ spores, $\mathrm{D}$ - basidia. Scale bars $=10 \mu \mathrm{m}$. 
DistRIBUTION, HABITAT AND REMARKs: Very rare European ink-cap species, known from Netherlands, Great Britain and Scandinavian Countries, growing solitary on bare soil and in grasslands. According to Wojewoda (2003) it is a synonym of Parasola leiocephala (P.D. Orton) Redhead, Vilgalys \& Hopple. However, there are distinct differences between these two species in spores shape and pileus color. Parasola galericuliformis and P. leiocephala are "good", disparate species in opinions of many others authors, e.g., Uljé (2005), Orton, Watling (1979), Vesterholt (2008d) or Legon et al. (2005). Hitherto not mentioned from Poland.

Parasola kuehneri (Uljé \& Bas) Redhead, Vilgalys \& Hopple (Coprinus kuehneri Uljé \& Bas)

Description And iconography: Uljé (2005): 35-36, Fig. 3; Ludwig (2007a): 72, Tabl. 258, Fig. 93.13A\&B; Ludwig (2007b): 162-163; Moser (2002): III/ Coprinus/18; Breitenbach, Kränzlin (1995): Vol. 4, Fig. 285.

Localities: 1. 2 km S from Lusowo village near Poznań; ATPOL: BD-07. One basidiocarp was found on forest path, under Populus tremula, Corylus avellana and Fraxinus excelsior, among mosses; 06.09.2009 \& 23.05.2010; leg., det. B. Gierczyk; BGF/090906/0002 \& BGF/100523/0001. 2. Poznań, western part of "Uroczysko Marcelin" forest, along the black bicycle route, near Junikowski stream; ATPOL: BD-08. Two individuals grew at the road-side, on moist soil, under Alnus glutinosa; 11.06.2009; leg., det. B. Gierczyk; BGF/090611/0001. 3. Poznań city, along Al. Wielkopolska street; ATPOL: BD-08. One basidiocarp was found on soil mixed with wood-chips under Aesculus hippocastanum trees; 21.05.2010; BGF/100521/0006. 4. Węgierska Górka village; ATPOL: DG-13. A few basidiocarps were collected in garden, among grasses; 15.05.2010; leg. R. Taran, det. B. Gierczyk; BGF/ $\mathrm{BF} / 100515 / 0003$.

Distribution AND REMARKs: Species probably widespread and common in Europe, but rarely recorded, known from Germany, Scandinavian Countries, France, Italy, Netherlands, growing on naked soil under trees and shrubs or in grassy places. In Poland found hitherto in two localities: Brodogóry reserve and Poznań (Lisiewska, Mikołajczak 1998; Stasińska 2003). Probably misidentified as other Parasola species.

Parasola leiocephala (P.D. Orton) Redhead, Vilgalys \& Hopple (C. leiocephalus P.D. Orton)

DESCRIPTION AND ICONOGRAPHY: Uljé (2005): 34-35, Fig. 2; Orton, Watling (1979): 102-103, 146-147, Fig. 219; Ludwig (2007a): 72, Tabl. 258, Fig. 93.12A-E; Ludwig (2007b): 160-161; Moser (2002): III/Coprinus/24; Breitenbach, Kränzlin (1995): Vol. 4, Fig. 290.

Localities: 1. Kaczawskie Plateau, $0.5 \mathrm{~km}$ SW from Przeździedza village, Forest District Lwówek Śląski, compartment no. 23a; ATPOL: AE-59. One basidiocarp grew on soil between oak and alder forests, on log-rolling road; 01.09.2009; leg. J. Soboń, det. B. Gierczyk; BGF/BF/090901/0001. 2. Kaczawskie Mts, 1 km W from Tarczyn village, Forest District Lwówek Śląski, compartment no. 137d; ATPOL: AE59. One basidiocarp grew on soil in alder forest, on old fish pond; 09.09.2008; leg. J. Soboń, det. B. Gierczyk; BGF/BF/080909/0001. 3. Poznań, western part "Uroczysko Marcelin" forest, near a Junikowski stream and the black bicycle route; ATPOL: 
BD-08. A dozen basidiocarps were found on moist soil, at the road-side, under Alnus glutinosa; 15.08.2009, 29.08.2009; leg., det. B. Gierczyk; BGF/090815/0002, BGF/090829/0002. 4. Poznań, eastern part of "Uroczysko Marcelin" forest, near allotments in Leśnych Skrzatów street; ATPOL: BD-08. A dozen basidiocarps were found on soil, at the road-side; 08.08.2009, 03.10.2009; leg., det. B. Gierczyk; BGF/090808/0001, BGF/091003/0001. 5. Poznań city, along Al. Wielkopolska street; ATPOL: BD-08. Two basidiocarps were found on soil mixed with wood-chips under Aesculus hippocastanum trees; 21.05.2010; BGF/100521/0003. 6. Jankowo Dolne village, near Jankowo Lake; ATPOL: CC-84. A few basidiocarps were found on the moist ground, under Alnus sp.; 23.05.2009; leg. B. Kudławiec, det. B. Gierczyk; BGF/BF/090523/0001. 7. Szałe near Kalisz, allotments; ATPOL: CD-87. Two basidiocarps were found in lawn; 00.06.2009; leg. N. Kolasińska, det. B. Gierczyk; BGF/090600/0002. 8. Dezydery Chłapowski Landscape Park, Turew, in a palace park; ATPOL: DB-48. One individual grew on soil, near the path, under Forsythia sp.; 17.08.2009; leg., det. B. Gierczyk; BGF/090817/0001. 9. Manorial park around the Habsburgs Palace in Żywiec village; ATPOL: DG-04. A few basidiocarps on the wood chips; 15.05.2010; leg. R. Taran, det. B. Gierczyk; BGF/BF/100515/0002. 10. Bieszczady Mts, grassy place near the rest-house in Zatwarnica village; ATPOL: FG-58. One basidiocarp was found on soil, among herbaceous plants in wet place; 29.06.2009; leg. A. Szczepkowski, det. B. Gierczyk; BGF/090629/0001. 11. Bieszczady Mts, Bieszczady National Park, along the blue tourist trail between Bukowe Berdo Mt. and Pszczeliny village; ATPOL: FG-69. One individual was found on soil in beech forest; 19.08.2009; leg., det. B. Gierczyk; BGF/090819/0001. 12. Białowieża Primeval Forest, Białowieża National Park, compartment no. 400, along the forest road; ATPOL: GC-55. A few basidiocarps were found on the ground, in Tilio-Carpinetum; 19.09.2009; leg., det. B. Gierczyk; BGF/090919/0017. 13. Białowieża Primeval Forest, near Białowieża, next to the didactic trail "Żebra Żubra", ATPOL: GC-65. One fruitbody grew on the ground in mixed forest (Picea abies, Carpinus betulus, Quercus robur, Alnus glutinosa); 15.09.2008; leg., det. B. Gierczyk; BGF080915/0007.

DistRIBUTION AND REMARKS: The species widespread in Europe and probably on other continents, known from Great Britain, Netherlands and Scandinavian Countries, rather common. Grows terrestrial on bare soil, often in grasslands and meadows or under threes. Recorded only in five localities in Poland (Wojewoda 2003; Nita, Bujakiewicz 2005; Łuszczyński 2007, 2008; Bujakiewicz, Stefaniak 2009), probably misidentified as other Parasola species.

Parasola megasperma (P.D. Orton) Redhead, Vilgalys \& Hopple (Coprinus megaspermus P.D. Orton)

Fig. 32

Description AND ICONOGRAPHY: Uljé (2005): 39-40, Fig. 10; Orton, Watling (1979): 100, 146-147, Fig. 220; Ludwig (2007a): 72, Tabl. 258, Fig. 93.15; Ludwig (2007b): 164-165.

MACROSCOPIC AND MICROSCOPIC FEATURES: Basidiocarps medium-sized, pileus 25$30 \mathrm{~mm}$, first ellipsoid to ovoid, then campanulate to flat, sulcate to the centre, stipe $100 \times 1-2 \mathrm{~mm}$. Pileus rusty, fulvous to cinnamon, stipe whitish to greyish. Spores 15.0-17.0 × 9.0-10.0 × 8.0-9.0 um (lit. 12.5-17.0 × 9.0-11.5 × 7.5-10.0 um), ellipsoid, slightly flattened, very dark brown to black, germ pore eccentric. Basidia 4-spored, 20-30 × 10-11 um (lit. 20-40 × 9-12 um). Cheilocystidia utriform to ellipsoid, 45-60 

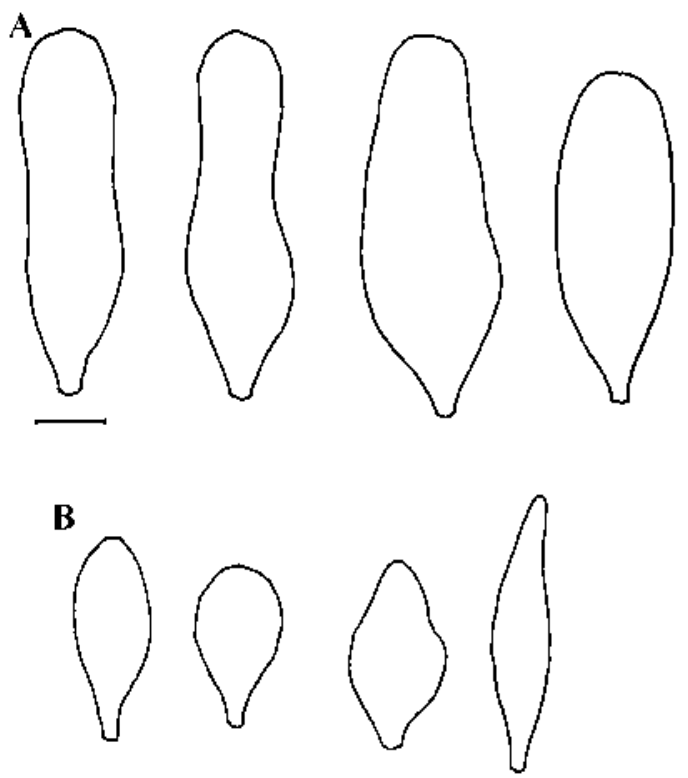

C
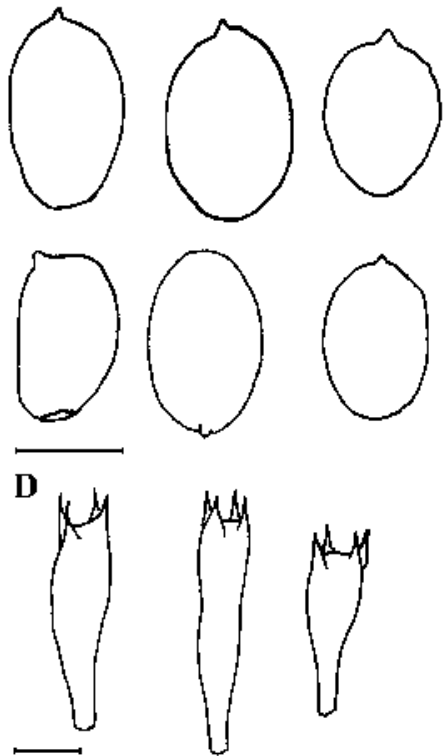

Fig. 32. Parasola megasperma microcharacters: A - pleurocystidia, B - cheilocystidia, $\mathrm{C}$ - spores, D - basidia. Scale bars $=10 \mu \mathrm{m}$.

$\times 15-22 \mu \mathrm{m}$ (lit. 40-60 × 13-24 $\mu \mathrm{m}$ ). Pleurocystidia utriform to sublageniform, 60-80 $\times$ 20-22 um (lit. 55-75 × 20-24 $\mu \mathrm{m}$ ). Clamp-connections present. Solitary, terrestrial (sometimes on dung).

Localities: 1. Poznań, southern part of "Uroczysko Marcelin" forest, grassland at the end of Jeleniogórska street; ATPOL: BD-08. One basidiocarp grew on soil, in a psammophilous grassland, near Betula pendula and Padus serotina shrubs; 13.06.2009; leg., det. B. Gierczyk; BGF/090613/0001. 2. Poznań city, along Al. Wielkopolska street; ATPOL: BD-08. Tens of basidiocarps were collected on soil mixed with wood-chips under Aesculus hippocastanum trees; 21.05.2010; leg. det. B. Gierczyk; BGF/100521/0004. 3. Bieszczady National Park, horse stud in Wołosate village, ATPOL: FG-79. A dozen of fruitbodies were found on horse dung mixed with straw; 06.10.2009, 05.06.2010; leg., det. B. Gierczyk; BGF/091006/0004, BGF/100605/0006.

Distribution, HABITAT AND REMARKs: Rare species, known from Netherlands, Great Britain, Denmark and Finland, growing solitary on soil or sometimes, on dung. Hitherto not mentioned from Poland.

Parasola misera (P. Karst.) Redhead, Vilgalys \& Hopple (Coprinus miser P. Karst.)

Description AND ICONOGRAPHY: Uljé (2005): 39, Fig. 9; Orton, Watling (1979): 104-105, 146-147, Fig. 224, 226; Ludwig (2007a): 73, Tabl. 259: 93.18; Ludwig (2007b): 166-167; Moser (2002): III/ Coprinus/25; Doveri (2004): 189-191.

LocAlities: 1. Kaczawskie Plateau, $2.5 \mathrm{~km}$ N from Wleń village, Forest District Lwówek Śląski, compartment no. 25a; ATPOL: AE-59. A few basidiocarps grew on soil mixed with dung in deciduous forest; 06.10.2009; leg. J. Soboń, det. B. Gierczyk; 
BGF/BF/091006/0001. 2. Bieszczady National Park, horse stud in Wołosate village, ATPOL: FG-79. Two fruitbodies were found on horse dung mixed with straw; 26.06.2009; leg. T. Pachlewski, det. B. Gierczyk; BGF/090626/0001.

DistrIBUTION AND REMARKS: Common and widespread European coprophilous species, growing on herbivores dung. Overlooked because of a minute basidiocarps. Known from three localities in Poland, all in National Parks: Karkonosze NP, Roztocze NP and Białowieża NP (Sałata 1972; Lisiewska 1992; Faliński et al. 1997).

\section{Parasola schroeteri (P. Karst.) Redhead, Vilgalys \& Hopple (Coprinus schroeteri P. Karst.)}

Description And iconography: Uljé (2005): 38, Fig. 7; Doveri (2004): 191-194.

Localities: Poznań, western part of "Uroczysko Marcelin" forest, at the crossing of the Dziewińska street with black bicycle route; ATPOL: BD-08. Dozen of fruitbodies were found on soil, in grassy place under Lonicera xylosteum shrubs; 06.06.2009, 12.06.2009, 08.05.2010; leg., det. B. Gierczyk; BGF/090606/0001, BGF/090612/00002, $\mathrm{BGF} / 100508 / 0002$.

Distribution AND REMARKs: Species described from Canada, widespread but rarely reported from Europe (Denmark, Finland, Italy, Norway, Netherlands). Known also under the name Coprinus nudiceps P.D. Orton, but according to Uljé \& Bender (1997) the name of Karsten has priority over C. nudiceps. Sometimes recognized as a variety of $C$. angulatus Peck non J.E. Lange, which was, however, placed within other genus - Coprinellus, and differs in spore shape and in presence of pileocystidia. It grows terrestrial and on dung. In Poland, $P$. schroeteri was found few times on dung cultures in laboratory, in XIX century (Wojewoda 2003).

\section{CONCLUSIONS}

Fungi belonging to the genera Coprinus, Coprinopsis, Coprinellus and Parasola are poorly recognized in Poland. Many common and widespread European species hitherto were not mentioned in the Polish mycological literature or are known only from scarce localities. It is quite plausible that some species (e.g., Parasola leiocephala, Coprinopsis jonesii) were misidentified as other ink-caps, therefore a revision of $\mathrm{Co}$ prinus s. lato collections in the Polish herbaria is necessary. More attention should also be given to rarely investigated habitats, as studs, pastures or compost-prisms where many ink-cap species new to Poland or uncommonly recorded could be find.

Acknowledgements. Authors wish to thank Grażyna Domian and Kamil Kędra for their help during field works in Bieszczady Mts and Białowieża Primeval Forest on August 2009, to Grażyna Domian, Marcin Fałdziński, Mirosław Gryc, Dariusz Karasiński, Natalia Kolasińska, Krzysztof Kołodziejczyk, Barbara Kudławiec, Jacek Lichoń, Jacek Nowicki, Robert Puciata, Jacek Soboń, Ryszard Taran and Piotr Zawada for collecting and sending ink-cap specimens and to Dr Anna Ronikier (IB PAN) for her help in literature collection. Our gratitude goes also to the authorities of Bieszczady National Park and Białowieża National Park for permissions to collect materials used in this studies. We wish also to thank Marcin Fałdzinski and Dariusz Karasiński for ink-caps photographs. 


\section{REFERENCES}

Adamczyk J. 2003a. Grzyby wielkoowocnikowe zespołów Tilio-Carpinetum melittetosum i CalamagrostioQuercetum petraeae rezerwatu leśnego Zielona Góra w północnej części Wyżyny Częstochowskiej. Ziemia Częstochowska 31: 123-138.

Adamczyk J. 2003b. Grzyby wielkoowocnikowe rezerwatu leśnego „Ostrężnik” na obszarze projektowanego Jurajskiego Parku Narodowego (Wyżyna Częstochowska). Ziemia Częstochowska 30: 177-193.

Adamczyk J., Głowacki Ł., Penczak T. 2004. Structure of macrofungus communities in different habitats of small postglacial pond margins. Acta Oecologica 25: 53-60.

Breitenbach J., Kränzlin F. 1995. Fungi of Switzerland. 4. Agarics., Richmond Publishing Company, Lucerna.

Bujakiewicz A. 1973. Udział grzybów wyższych w lasach łęgowych i olesach Wielkopolski. Pozn. Tow. Przyj. Nauk. Wydz. Mat.-Przyr. Prace Kom. Biol. 35 (6): 335-423.

Bujakiewicz A. 2004. Grzyby wielkoowocnikowe Babiogórskiego Parku Narodowego. (In:) B. Wołoszyn, A. Jaworski, J. Szwagrzyk (eds). Babiogórski Park Narodowy. Monografia Przyrodnicza. Wydawnictwo Komitetu Ochrony Przyrody PAN i Babiogórskiego Parku Narodowego, Kraków: 215-257.

Bujakiewicz A. 2006. Macrofungi in the Caltho-Alnetum association on the northern slopes of the Babia Góra massif (west Carpathians). Pol. Bot. Studies 22: 81-93.

Bujakiewicz A. 2010. On some agarics occurring in carr forests. Acta Mycol. 45 (1): 73-89.

Bujakiewicz A., Kujawa A. 2010. Grzyby wielkoowocnikowe wybranych rezerwatów przyrody Puszczy Białowieskiej. Parki nar. Rez. Przyr. 29 (1): 3-26.

Bujakiewicz A., Springer N. 2009. Udział macromycetes w lasach łęgowych rezerwatu „Buki nad Jeziorem Lutomskim" (nadleśnictwo Sieraków). Bad. Fizjogr. Pol. Zach. 58: 171-204.

Bujakiewicz A., Stefaniak M. 2009. Udział macromycetes w fitocenozach leśnych rezerwatu „Las Liściasty w Promnie" (nadleśnictwo Czerniejewo). Bad. Fizjogr. Pol. Zach. 58: 137-170.

Chmiel M.A., Sadowska B. 1994. Grzyby koprofilne w zbiorowiskach leśnych Białowieskiego Parku Narodowego. Fragm. Flor. Geobot. Pol. 1: 107-132.

Doveri F. 2004. Fungi fimicoli italici. A guide to the recognition of basidiomycetes and ascomycetes living on faecal material. A.M.B. Fondazione Centro Studi Mycologici, Vicenza.

Faliński J.B., Mułenko W., Bujakiewicz A., Majewski T. (eds). 1997. Cryptogamous plants in the forest communities of Białowieża National Park. Ecological Atlas (Project CRYPTO 4). Phytocenosis 9 (N.S.) Suppl. Cartogr. Geobot. 7: 1-522.

Flisińska Z. 2004. Grzyby Lubelszczyzny. Wielkoowocnikowe podstawczaki (Basidiomycetes). 2. Lubelskie Towarzystwo Naukowe.

Gierczyk B., Chachuła P., Karasiński D., Kujawa A., Kujawa K., Pachlewski T., Snowarski M., Szczepkowski A., Ślusarczyk T., Wójtowski M. 2009. Grzyby wielkoowocnikowe polskich Bieszczadów. I. Parki nar. Rez. Przyr. 28 (3): 3-100.

Halama M., Romański M. 2010. Grzyby makroskopowe (macromycetes). (In:) L. Krzysztofiak (ed.). Śluzowce Myxomycetes, grzyby Fungi i mszaki Bryophyta Wigierskiego Parku Narodowego. Przyroda Wigierskiego Parku Narodowego. Seria naukowa. Stowarzyszenie „Człowiek i Przyroda“, Suwałki: 87-201.

Hopple J.S., Vilgalys R. 1999. Phylogenetic relationships in the mushroom genus Coprinus and darkspored allies based on sequence data from the nuclear gene coding for the large ribosomal subunit RNA: divergent domains, outgroups, and monophyly. Mol. Phyl. Evol. 13: 1-19.

Kirk P.M., Cannon P. F., Minter D. W., Stalpers J. A. (eds). 2008. Ainsworth \& Bisby's Dictionary of the Fungi, $10^{\text {th }}$ ed. CABI, Wallingford, $759 \mathrm{pp}$.

Kujawa A. 2009. Macrofungi of wooded patches in the agricultural landscape. I. Species diversity. Acta Mycol. 44 (1): 49-74.

Legon N.W., Henrici A., Roberts P.J., Spooner B.M., Watling R. 2005. Checklist of the British \& Irish Basidiomycota. Royal Botanic Gardens, Kew.

Lisiewska M. 1992. Wpływ obecności paśników na pojaw synantropijnych macromycetes w Karkonoskim Parku Narodowym. Bad. Fizjogr. Pol. Zach. 41: 149-174.

Lisiewska M., Galas-Świdurska D. 2005. Podstawczaki (Basidiomycetes) Ogrodu Dendrologicznego Akademii Rolniczej w Poznaniu. Bad. Fizjogr. Pol. Zach. 54: 35-65.

Lisiewska M., Mikołajczak M. 1998. Ogród Botaniczny Uniwersytetu im. A. Mickiewicza w Poznaniu jako środowisko przyrodnicze grzybów wielkoowocnikowych. Bad. Fizjogr. Pol. Zach. 47:7-44. 
Lisiewska M., Rybak M. 1990. Udział macromycetes w zespołach leśnych parku w Uniejowie. Bad. Fizjogr. Pol. Zach. 40: 5-28.

Ludwig E. 2007a. Pilzkompendium. Band 2. Abbildungen. Die größeren Gattungen der Agaricales mit farbigem Sporenpulver (ausgenommen Cortinariaceae). Fungicon-Verlag, Berlin.

Ludwig E. 2007b. Pilzkompendium. Band 2. Beschreibungen. Die größeren Gattungen der Agaricales mit farbigem Sporenpulver (ausgenommen Cortinariaceae). Fungicon-Verlag, Berlin.

Łuszczyński J. 2007. Diversity of Basidiomycetes in various ecosystems of the Góry Świętokrzyskie Mts. Monogr. Bot. 97: 5-218.

Łuszczyński J. 2008. Basidiomycetes of the Góry Świętokrzyskie Mts. A checklist. Wydawnictwo Uniwersytetu Humanistyczno-Przyrodniczego Jana Kochanowskiego, Kielce.

Moncalvo J.-M., Vilgalys R., Redhead S.A., Johnson J.E. James T.Y., Aime M.C., Hofstetter V., Verduin S.J.W., Larsson E., Baroni T.J., Thorn R.-G., Jacobsson S., Clémençon H., Miller O.K. 2002. One hundred and seventeen clades of euagarics. Mol. Phyl. Evol. 23: 357-400.

Moser M. (unter Mitarbeit von F. Bellú, A. Hausknecht, U. Pelntner). 2002. Farbatlas der Basidiomyceten. Spektrum Akademischer Verlag Heidelberg, Berlin.

Nagy L. 2007. Notes on taxa of Coprinus subsection Alachuani from Hungary. Österr. Z. Pilzk. 16: 167180.

Nita J., Bujakiewicz A. 2005. Grzyby wielkoowocnikowe w fitocenozach łęgu wiązowego Querco-Ulmetum minoris i olsu Carici elongatae-Alnetum w Lesie Złotowskim (Pomorze Zachodnie). Bad. Fizjogr. Pol. Zach. 54: 7-33.

Nita J., Bujakiewicz A. 2007. Łęgi i olsy ostoją rzadkich i zagrożonych grzybów wielkoowocnikowych. Studia i Materiały. Centrum Edukacji Przyrodniczo-Leśnej 9 (2/3): 519-529.

Nita J., Bujakiewicz A. 2009. Riparian and alder forests - shelters for rare and threatened macromycetes. (In:) Z. Mirek, A. Nikiel (eds). Rare, relict and endangered plants and fungi in Poland. W. Szafer Institute of Botany, Polish academy of Sciences, Kraków: 325-334.

Orton P. D., Watling R. 1979. Coprinaceae Part 1: Coprinus. (In:) D. M. Henderson, P. D. Orton, R. Watling (eds). British Fungus Flora. Agarics and Boleti. 2. Edynburg.

Redhead S.A., Vilgalys R., Moncalvo J.-M., Johnson J., Hopple J.S., 2001. Coprinus Pers. and the disposition of Coprinus species sensu lato. Taxon 50: 203-241.

Sadowska B. 1973. Preliminary evaluation of the productivity of fungi (Agaricales and Gasteromycetes) on the Kazuń meadows. Acta Mycol. 9 (1): 91-100.

Sałata B. 1972. Badania nad udziałem grzybów wyższych w lasach bukowych i jodłowych na Roztoczu Środkowym. Acta Mycol. 8 (1): 69-139.

Skirgiełło A. 1946. Przyczynek do znajomości flory mikologicznej okolic Kuźnicy Grodzieńskiej. Acta Soc. Bot. Pol. 17 (2): 239-251.

Ślusarczyk T. 2004. Grzyby wielkoowocnikowe rezerwatu torfowiskowego „Pniowski Ług”. Przegląd Przyr. 15: 19-27.

Stasińska M. 2003. Różnorodność grzybów (macromycetes) w warunkach naturalnej sukcesji muraw stepowych. (In:) S. M. Rogalika, J. Domagała (eds). Człowiek i środowisko przyrodnicze Pomorza Zachodniego. Szczecin: 31-34.

Svrček M. 1983. New or uncommon Agaricales from Bohemia. Česká Mykologie 37 (4): 212-236.

Uljé C. B. 2005. Coprinus. (In:) M. E. Noordeloos, T. W. Kuyper, E. C. Vellinga (eds). Flora Agaricina Neerlandica. Critical monograps on families of agarics and boleti occurring in the Netherlands. 6. Taylor\&Francis Group, Boca Raton: 22-109.

Uljé C.B., Bender H. 1997. Additional studies in Coprinus subsection Glabri. Persoonia 16 (3): 373-381.

Vellinga E.C. 2004. Genera in the family Agaricaceae - Evidence from nrITS and nrLSU sequences. Mycol. Res. 108: 354-377.

Vesterholt J. 2008a. Coprinellus P. Karst. (In:) H. Knudsen, J. Vesterholt (eds). Funga Nordica. Agaricoid, boletoid and cyphelloid genera. Nordsvamp, Copenhagen: 558-568.

Vesterholt J. 2008b. Coprinopsis P. Karst. (In:) H. Knudsen, J. Vesterholt (eds). Funga Nordica. Agaricoid, boletoid and cyphelloid genera. Nordsvamp, Copenhagen: 568-583.

Vesterholt J. 2008c. Coprinus Pers. (In:) H. Knudsen, J. Vesterholt (eds). Funga Nordica. Agaricoid, boletoid and cyphelloid genera. Nordsvamp, Copenhagen: 532-533.

Vesterholt J. 2008d. Parasola Redhead, Vilgalys \& Hopple. (In:) H. Knudsen, J. Vesterholt (eds). Funga Nordica. Agaricoid, boletoid and cyphelloid genera. Nordsvamp, Copenhagen: 584-586.

Vesterholt J., Rald E., Læssøe T. 2007. Slægten Hjulhat (Parasola) i Danmark. Svampe 45: 1-10. 
Wojewoda W. 1996. Grzyby Krakowa w latach 1883-1994 ze szczególnym uwzględnieniem Macromycetes. Studia Ośr. Dokument. Fizjogr. PAN, Kraków 24: 75-111.

Wojewoda W. 2003. Checklist of polish larger Basidiomycetes. (In:) Z. Mirek (ed.). Biodiversity of Poland. 7. W. Szafer Institute of Botany, Polish Academy of Sciences, Kraków.

Wojewoda W., Ławrynowicz M. 2006. Red list of the macrofungi in Poland. (In:) Z. Mirek, K. Zarzycki, W. Wojewoda, Z. Szeląg (eds). Red list of plants and fungi in Poland. W. Szafer Institute of Botany, Polish Academy of Sciences, Kraków: 53-70.

http://users.raketnet.nl/keesuljee/argenteus.htm

Rzadkie gatunki z rodzaju Coprinus Pers. s. lato

\section{Streszczenie}

Dotychczas, w literaturze mykologicznej dotyczącej obszaru Polski, wymienionych zostało 54 gatunków grzybów należących do rodzaju Coprinus Pers. s. lato. (czernidlak), co stanowi zaledwie $1 / 3$ ogółu gatunków z tej grupy, znanych z Europy. W niniejszej publikacji zaprezentowano nowe stanowiska 55 gatunków czernidlaków wg najnowszego podziału systematycznego, wyróżniającego w ramach dawnego rodzaju czernidlak 4 rodzaje: Coprinus Pers., Coprinellus P. Karst., Coprinopsis P. Karst. i Parasola Redhead, Vilgalys \& Hopple, przy czym 28 z nich to gatunki nie podawane wcześniej z terenu Polski a 23 - gatunki znane z pojedynczych, często historycznych, stanowisk. Ponadto do pracy włączono 4 gatunki wymieniane, jako nowe dla naszego kraju w opracowaniu o mykobiocie Bieszczadów (Gierczyk i in. 2009) bez szczegółowego opisu. Dla wszystkich nowych dla Polski grzybów z rodzaju Coprinus Pers. s. lato zaprezentowano opis cech makro- i mikroskopowych w oparciu o znalezione owocniki i dane $\mathrm{z}$ literatury. 